\title{
Article
}

\section{Pain relief for women with cervical intraepithelial neoplasia undergoing colposcopy treatment}

Gajjar, Ketan, Martin-Hirsch, Pierre PL, Bryant, Andrew and Gajjar, Ketan

Available at https://clok.uclan.ac.uk/9093/

Gajjar, Ketan, Martin-Hirsch, Pierre PL, Bryant, Andrew and Gajjar, Ketan (2012) Pain relief for women with cervical intraepithelial neoplasia undergoing colposcopy treatment. The Cochrane Library . pp. 1-71. ISSN 1465-1858

It is advisable to refer to the publisher's version if you intend to cite from the work.

http://dx.doi.org/10.1002/14651858.CD006120.pub3

For more information about UCLan's research in this area go to http://www.uclan.ac.uk/researchgroups/ and search for <name of research Group>.

For information about Research generally at UCLan please go to http://www.uclan.ac.uk/research/

All outputs in CLoK are protected by Intellectual Property Rights law, including Copyright law. Copyright, IPR and Moral Rights for the works on this site are retained by the individual authors and/or other copyright owners. Terms and conditions for use of this material are defined in the policies page.

\section{CLoK}

Central Lancashire online Knowledge www.clok.uclan.ac.uk

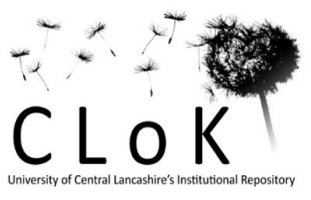




\section{Pain relief for women with cervical intraepithelial neoplasia undergoing colposcopy treatment (Review)}

Gajjar K, Martin-Hirsch PPL, Bryant A

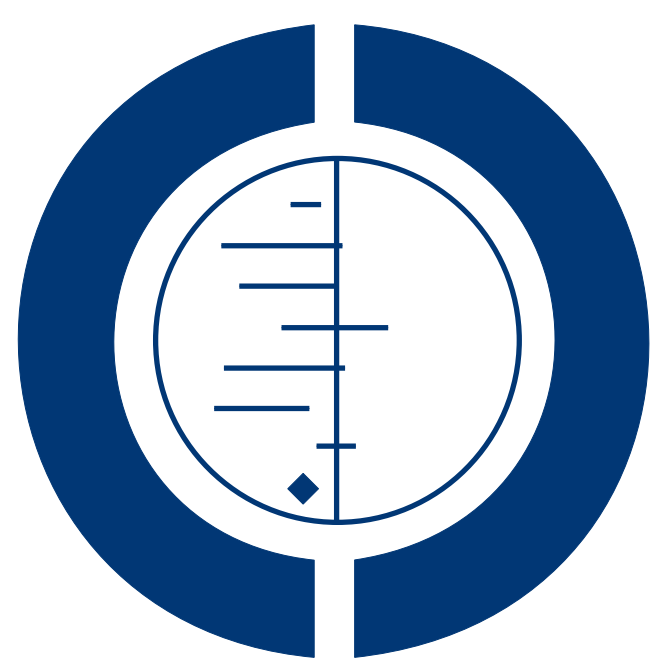

\section{THE COCHRANE COLLABORATION ${ }^{\circledR}$}

This is a reprint of a Cochrane review, prepared and maintained by The Cochrane Collaboration and published in The Cochrane Library 2012, Issue 10

http://www.thecochranelibrary.com

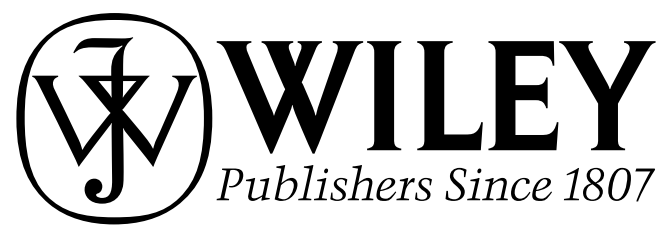

Pain relief for women with cervical intraepithelial neoplasia undergoing colposcopy treatment (Review)

Copyright $\odot 2012$ The Cochrane Collaboration. Published by John Wiley \& Sons, Ltd. 
TABLE OF CONTENTS

HEADER . . . . . . . . . . . . . . . . . . . . . . . . . . . . . . . . . . . . . . . . . . . . . . . . . . . .

ABSTRACT . . . . . . . . . . . . . . . . . . . . . . . . . . . . . . . . . . . . . . . . . . . . . . . . . . . . .

PLAIN LANGUAGE SUMMARY . . . . . . . . . . . . . . . . . . . . . . . . . . . . . . . . . . . . . . . . . . . .

BACKGROUND . . . . . . . . . . . . . . . . . . . . . . . . . . . . . . . . . . . . . 3

OBJECTIVES . . . . . . . . . . . . . . . . . . . . . . . . . . . . . . . . . . . . . . . . . . . . . . . . . . . .

METHODS . . . . . . . . . . . . . . . . . . . . . . . . . . . . . . . . . . . . . . 4

RESUlTS . . . . . . . . . . . . . . . . . . . . . . . . . . . . . . . . . . . . . . . . . .

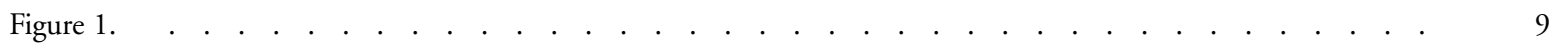

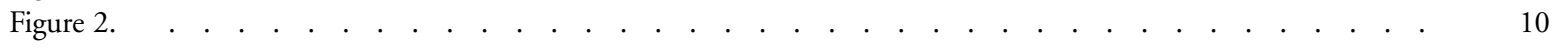

DISCUSSION . . . . . . . . . . . . . . . . . . . . . . . . . . . . . . . . . . . . . . . . . .

AUTHORS' CONCLUSIONS . . . . . . . . . . . . . . . . . . . . . . . . . . . . . . . . . . . . . . . . . .

ACKNOWLEDGEMENTS . . . . . . . . . . . . . . . . . . . . . . . . . . . . . . . . . . . . . . . . . . . . .

REFERENCES . . . . . . . . . . . . . . . . . . . . . . . . . . . . . . . . . . . . . . . . . . . . . . . .

CHARACTERISTICS OF STUDIES . . . . . . . . . . . . . . . . . . . . . . . . . . . . . . . . . . . . . . . . . . .

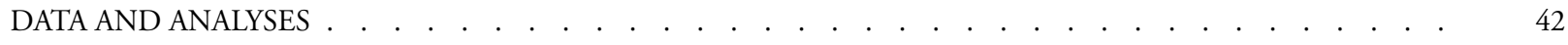

Analysis 1.1. Comparison 1 Local anaesthetic (lignocaine 2\%) injection versus control (saline injection), Outcome 1 Pain

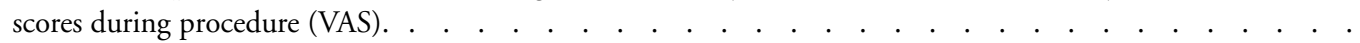

Analysis 1.2. Comparison 1 Local anaesthetic (lignocaine 2\%) injection versus control (saline injection), Outcome 2 Moderate to severe pain.

Analysis 2.1. Comparison 2 Local anaesthetic plus vasoconstrictor versus control, Outcome 1 Pain scores during procedure (VAS: 0-100). . . . . . . . . . . . . . . . . . . . . . . . . . . . . . . . . . . 47

Analysis 2.2. Comparison 2 Local anaesthetic plus vasoconstrictor versus control, Outcome 2 Moderate or severe pain. 48

Analysis 2.3. Comparison 2 Local anaesthetic plus vasoconstrictor versus control, Outcome 3 Troublesome bleeding. 49

Analysis 3.1. Comparison 3 Local anaesthetic plus vasoconstrictor versus local anaesthetic injection alone, Outcome 1 Moderate or severe pain.

Analysis 3.2. Comparison 3 Local anaesthetic plus vasoconstrictor versus local anaesthetic injection alone, Outcome 2 Blood loss (volume).

Analysis 3.3. Comparison 3 Local anaesthetic plus vasoconstrictor versus local anaesthetic injection alone, Outcome 3

Duration of treatment. .

Analysis 4.1. Comparison 4 Prilocaine plus felypressin versus lignocaine plus adrenaline, Outcome 1 Pain (using 6 category scale).

Analysis 4.2. Comparison 4 Prilocaine plus felypressin versus lignocaine plus adrenaline, Outcome 2 Blood loss $(0-5$ scale).

Analysis 5.1. Comparison 5 Deep plus superficial versus deep cervical injection, Outcome 1 Pain scores during procedure (VAS: 0-100). . . . . . . . . . . . . . . . . . . . . . . . . . . . . . . . . . . . . . . .

Analysis 6.1. Comparison 6 Oral analgesic versus control, Outcome 1 Pain scores (VAS: 0-100). $\quad . \quad$. . . . . . . . 53

Analysis 6.2. Comparison 6 Oral analgesic versus control, Outcome 2 Moderate to severe pain. . . . . . . . . . . . . . . 54

Analysis 6.3. Comparison 6 Oral analgesic versus control, Outcome 3 Pain relief required in first 24 hours. . . . . . 54

Analysis 7.1. Comparison 7 Inhalation analgesia versus placebo, Outcome 1 Pain scores (VAS: 0-100). . . . . . . 55

Analysis 7.2. Comparison 7 Inhalation analgesia versus placebo, Outcome 2 Heavy vaginal bleeding. . . . . . . 55

Analysis 7.3. Comparison 7 Inhalation analgesia versus placebo, Outcome 3 Anxiety - HAD score. . . . . . . . 56

Analysis 8.1. Comparison 8 Topical application versus placebo, Outcome 1 Pain scores during procedure (VAS: 0-100). 56

Analysis 8.2. Comparison 8 Topical application versus placebo, Outcome 2 Duration of treatment. $\quad . \quad$. . . . . $\quad 57$

Analysis 9.1. Comparison 9 Cocaine spray versus placebo, Outcome 1 Pain scores during procedure (VAS: 0-100). .57

Analysis 9.2. Comparison 9 Cocaine spray versus placebo, Outcome 2 Moderate to severe pain. . . . . . . . . . . . 58

Analysis 9.3. Comparison 9 Cocaine spray versus placebo, Outcome 3 Troublesome bleeding. . . . . . . . . . . 58

Analysis 10.1. Comparison 10 TENS versus TENS plus local anaesthetic injection, Outcome 1 Troublesome blood loss. 59

Analysis 11.1. Comparison 11 TENS versus local anaesthetic injection, Outcome 1 Troublesome blood loss. . . . . 59

Analysis 12.1. Comparison 12 TENS plus local versus local anaesthetic injection, Outcome 1 Troublesome blood loss. 60

ADDITIONAL TABLES . . . . . . . . . . . . . . . . . . . . . . . . . . . . . . . . . . . . . . . . . 6

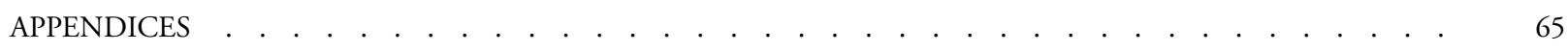

Pain relief for women with cervical intraepithelial neoplasia undergoing colposcopy treatment (Review)

Copyright ( 2012 The Cochrane Collaboration. Published by John Wiley \& Sons, Ltd.

(1)

(1)

1

1

2

3

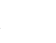

5

.

56

7

7

58
58

9

9

0


HISTORY . . . . . . . . . . . . . . . . . . . . . . . . . . . . . . . . . . . . . . . . . . . . . . .

CONTRIBUTIONS OF AUTHORS . . . . . . . . . . . . . . . . . . . . . . . . . . . . . . . . . . . . . . . .

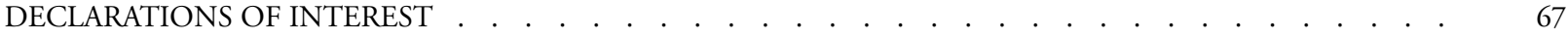

SOURCES OF SUPPORT . . . . . . . . . . . . . . . . . . . . . . . . . . . . . . . . . . . . . . . . . . . . . . . .

DIFFERENCES BETWEEN PROTOCOL AND REVIEW . . . . . . . . . . . . . . . . . . . . . . . . . . . . . 67

INDEX TERMS . . . . . . . . . . . . . . . . . . . . . . . . . . . . . . . . . . . . . 68 


\title{
[Intervention Review] \\ Pain relief for women with cervical intraepithelial neoplasia undergoing colposcopy treatment
}

\author{
Ketan Gajjar ${ }^{1}$, Pierre PL Martin-Hirsch ${ }^{1}$, Andrew Bryant ${ }^{2}$ \\ ${ }^{1}$ Gynaecological Oncology Unit, Royal Preston Hospital, Lancashire Teaching Hospital NHS Trust, Preston, UK. ${ }^{2}$ Institute of Health \\ and Society, Newcastle University, Newcastle upon Tyne, UK
}

Contact address: Ketan Gajjar, Gynaecological Oncology Unit, Royal Preston Hospital, Lancashire Teaching Hospital NHS Trust, Sharoe Green Lane, Fulwood, Preston, Lancashire, PR2 9HT, UK. gajjarkb@gmail.com.

Editorial group: Cochrane Gynaecological Cancer Group.

Publication status and date: New, published in Issue 10, 2012.

Review content assessed as up-to-date: 23 February 2012.

Citation: Gajjar K, Martin-Hirsch PPL, Bryant A. Pain relief for women with cervical intraepithelial neoplasia undergoing colposcopy treatment. Cochrane Database of Systematic Reviews 2012, Issue 10. Art. No.: CD006120. DOI: 10.1002/14651858.CD006120.pub3.

Copyright (C) 2012 The Cochrane Collaboration. Published by John Wiley \& Sons, Ltd.

\begin{abstract}
A B S T R A C T
Background

Pre-cancerous lesions of cervix (cervical intraepithelial neoplasia (CIN)) are usually treated with excisional or ablative procedures. In the UK, the NHS cervical screening guidelines suggest that over $80 \%$ of treatments should be performed in an outpatient setting (colposcopy clinics). Furthermore, these guidelines suggest that analgesia should always be given prior to laser or excisional treatments. Currently various pain relief strategies are employed that may reduce pain during these procedures.
\end{abstract}

Objectives

The aim of this review was to assess whether the administration of pain relief reduced pain during colposcopy treatment and in the postoperative period.

\section{Search methods}

We searched the Cochrane Gynaecological Cancer Review Group Specialised Register, Cochrane Central Register of Controlled Trials (CENTRAL - May 2011) (2011, Issue 2), MEDLINE (1950 to May week 2, 2011), EMBASE (1980 to week 20, 2011) for studies of any design relating to analgesia for colposcopic management. We also searched registers of clinical trials, abstracts of scientific meetings, reference lists of included studies and contacted experts in the field.

\section{Selection criteria}

Randomised controlled trials (RCTs) that compared all types of pain relief before, during or after outpatient treatment to the cervix, in adult women with CIN undergoing loop excision, laser ablation, laser excision or cryosurgery in an outpatient colposcopy clinic setting.

\section{Data collection and analysis}

We independently assessed study eligibility, extracted data and assessed risk of bias. We entered data into RevMan and double checked it for accuracy. Where possible, the results were expressed as mean pain score and standard error of the mean with $95 \%$ confidence intervals (CI) and the data were synthesised in a meta-analysis.

Pain relief for women with cervical intraepithelial neoplasia undergoing colposcopy treatment (Review)

Copyright $\odot 2012$ The Cochrane Collaboration. Published by John Wiley \& Sons, Ltd. 


\section{Main results}

We included 17 RCTs (1567 women) of varying methodological quality in the review. These trials compared a variety of interventions aimed at reducing pain in women who underwent treatment for CIN, including cervical injection with lignocaine alone, lignocaine with adrenaline, prilocaine with felypressin, oral analgesics (non-steroidal anti-inflammatory drugs (NSAIDs)), inhalation analgesia (gas mixture of isoflurane and desflurane), lignocaine spray, cocaine spray, local application of benzocaine gel, lignocaine-prilocaine cream (EMLA cream) and transcutaneous electrical nerve stimulation (TENS).

Most comparisons were restricted to single trial analyses and were under-powered to detect differences in pain scores between treatments that may or may not have been present. There was no significant difference in pain relief between women who received local anaesthetic infiltration (lignocaine 2\%; administered as a paracervical or direct cervical injection) and a saline placebo (2 trials; 130 women; MD 13.74; 95\% CI -34.32 to 6.83). However, when local anaesthetic was combined with a vasoconstrictor agent (one trial used lignocaine combined with adrenaline while the second trial used prilocaine combined with felypressin), significantly less pain (on visual analogue scores) occurred compared with no treatment (2 trials; 95 women; MD -23.73; 95\% CI -37.53 to -9.93). Comparing two preparations of local anaesthetic plus vasoconstrictor, prilocaine combined with felypressin did not differ from lignocaine combined with adrenaline for its effect on pain control ( 1 trial; 200 women; MD -0.05; 95\% CI -0.26 to 0.16). Although the mean observed blood loss score was less with lignocaine plus adrenaline $(1.33 \pm 1.05)$ as compared with prilocaine plus felypressin $(1.74 \pm 0.98)$, the difference was not clinically significant as the overall scores in both groups were low ( 1 trial; 200 women; MD $0.41 ; 95 \%$ CI 0.13 to 0.69 ). Inhalation of gas mixture (isoflurane and desflurane) in addition to standard cervical injection with prilocaine plus felypressin resulted in significantly less pain during the LLETZ (loop excision of the transformation zone) procedure ( 1 trial; 389 women; MD -7.20; $95 \%$ CI - 12.45 to -1.95). Lignocaine plus ornipressin resulted in significantly less measured blood loss ( 1 trial; 100 women; MD -8.75; $95 \%$ CI -10.43 to -7.07$)$ and a shorter duration of treatment ( 1 trial; 100 women; MD $-7.72 ; 95 \%$ CI -8.49 to -6.95$)$ than cervical infiltration with lignocaine alone.

One meta-analysis found no statistically significant difference in pain using visual analogue scores between women who received oral analgesic and those who received placebo ( 2 trials; 129 women; MD -3.51; 95\% CI -10.03 to 3.01; Analysis 6.1).

Cocaine spray was associated with significantly less pain ( 1 trial; 50 women; MD -28; 95\% CI -37.86 to -18.14) and blood loss (1 trial; 50 women; MD 0.04; 95\% CI 0 to 0.70 ) than placebo.

No serious adverse events were reported in any of the trials and majority of trials were at moderate or high risk of bias $(\mathrm{n}=12)$.

\section{Authors' conclusions}

Based on two small trials, there was no significant difference in pain relief in women receiving oral analgesics compared with placebo or no treatment (129 women; MD $-3.51 ; 95 \%$ CI -10.03 to 3.01). We consider this evidence to be of a low to moderate quality. In routine clinical practice, intracervical injection of local anaesthetic with a vasoconstrictor (lignocaine plus adrenaline or prilocaine plus felypressin) appears to be the optimum analgesia for treatment. However, further high-quality, adequately powered trials should be undertaken in order to provide the data necessary to estimate the efficacy of oral analgesics, the optimal route of administration and dose of local anaesthetics.

\section{PLAIN LANGUAGE SUMMARY}

Pain relief for women with pre-cancerous changes of the cervix (cervical intraepithelial neoplasia (CIN)) undergoing outpatient treatment

Treatment for CIN is usually undertaken in an outpatient colposcopy clinic to remove the pre-cancerous cells from the cervix. It commonly involves lifting the cells off the cervix with electrically heated wire (diathermy) or laser, or destroying the abnormal cells with freezing methods (cryotherapy). This is potentially a painful procedure. The purpose of this review is to determine which, if any, pain relief should be used during cervical colposcopy treatment. We identified 17 trials and these reported different forms of pain relief before, during and after colposcopy. Evidence from two small trials showed that women having a colposcopy treatment had less pain and blood loss if the cervix was injected with a combination of a local anaesthetic drug and a drug that causes blood vessels to constrict (narrow), compared with placebo. Although taking oral pain-relieving drugs (e.g. ibuprofen) before treatment on the cervix in the colposcopy clinic is recommended by most guidelines, evidence from two small trials did not show that this practice reduced pain during the procedure. Most of the evidence in this field is of a low to moderate quality and further research may change these findings. 
Additionally, we were unable to obtain evidence with regards to dosage of the local anaesthetic drug or method of administering local anaesthetic into the cervix. There is need for high-quality trials with sufficient numbers of participants in order to provide the data necessary to estimate these effects.

\section{B A C K G ROU N D}

\section{Description of the condition}

Cervical cancer is the second most common cancer among women up to 65 years of age and is the most frequent cause of death from gynaecological cancers worldwide. A woman's risk of developing cervical cancer by the age of 65 years ranges from $0.69 \%$ in developed countries to $1.38 \%$ in developing countries (GLOBOCAN 2008). In Europe, about $60 \%$ of women with cervical cancer are alive five years after diagnosis (EUROCARE 2003). Cervical screening has all the characteristics of a good screening programme. There are effective screening tests, such as the traditional cytological approach (Pap smear) for diagnosing pre-invasive and early invasive disease, or new methodologies, such as human papillomavirus (HPV) testing, which try to improve sensitivity and specificity. Also there are effective surgical treatments for pre-invasive and early invasive disease, which dramatically alter the prognosis. As cervical screening is relatively inexpensive, non-invasive and treatment of pre-invasive disease requires only simple surgical techniques, screening is cost-effective and has been clearly demonstrated to reduce mortality in countries with well-organised screening programmes (Peto 2004).

The effectiveness of different modalities of treatment for pre-invasive disease has been the subject of a previous Cochrane review (Martin-Hirsch 2010). In this review, each modality of treatment was assessed for its ability to eradicate disease and associated morbidity. Current treatment for cervical intraepithelial neoplasia (CIN) is by local ablative therapy or by excisional methods, depending on the nature and extent of the disease. There is an international consensus that the majority of these procedures can be performed within the colposcopy clinic in an outpatient setting. In the UK, the National Health Service (NHS) cervical screening guidelines suggest that over $80 \%$ of treatments should be performed in a clinic setting (NHSCSP 2004; NHSCSP 2010). Furthermore, these guidelines also suggest that analgesia should always be given prior to laser or excisional treatments.

\section{Description of the intervention}

Therapies that are available to treat pre-malignant lesions of the cervix in outpatient settings include loop diathermy excision, laser ablation or excision and cryotherapy (Martin-Hirsch 2010). Studies have reported variable outcomes with different types of pain relief for these procedures. The choice of pain relief in these studies varies from no analgesia to intracervical infiltration with anaesthetic agent (e.g. lignocaine or prilocaine) with or without vasopressor agents (e.g. adrenaline or felypressin) (Lee 1986; Johnson 1989). Other methods studied are oral therapy with non-steroidal anti-inflammatory drugs (NSAIDs) (Frega 1994), local spray with cocaine (Mikhail 1988), topical benzocaine gel (Lipscomb 1995), inhalation of gas mixture of isoflurane and desflurane (Cruickshank 2005), local anaesthetic cream (EMLA cream) (Sarkar 1993) and transcutaneous electrical nerve stimulation (TENS) (Crompton 1992).

\section{How the intervention might work}

The possible mechanisms proposed in the literature to explain pain during cervical laser vaporisation includes pain mediated through peripheral pain fibres in the cervix, stimulated by heat energy, with or without pain caused by increased uterine contractions, probably because of the release of prostaglandins. The interventions may work by blocking the pain pathways. The nerve supply to the cervix is unclear, but the richest supply appears to be at the level of internal os. The ectocervix appears to be relatively insensitive to extremes of temperature with few specialised nerve fibres (Jordan 1976). Pain stimuli from the cervix and vagina are conducted by visceral afferent fibres to the S2 to S4 spinal ganglia via the pudendal and pelvic splanchnic nerves, along with parasympathetic fibres (Moore 2006).

\section{Why it is important to do this review}

There now appears to be a consensus that analgesia should be administered before treatment to the cervix. Currently, there is no systematic review or meta-analysis evaluating whether administering analgesia reduces the pain experienced by patients undergoing outpatient treatment. Most guidelines are also not explicit on the nature of optimum analgesia for intra- and postoperative pain relief. Analgesia is commonly administered intra- or para-cervically using fine dental needles. Other routes of administering analgesics evaluated are TENS, peri-operative NSAIDs and inhalation analgesia. 


\section{O B J E C T I VES}

To assess whether the administration of anaesthesia reduces pain during colposcopy treatment and in the postoperative period.

\section{METHODS}

\section{Criteria for considering studies for this review}

\section{Types of studies}

Randomised controlled trials (RCTs)

\section{Types of participants}

Women with CIN undergoing loop excision, laser ablation, laser excision or cryosurgery treatment of the cervix in an outpatient colposcopy clinic setting.

\section{Types of interventions}

All types of pain relief before, during or after outpatient treatment to the cervix, compared with no pain relief or another type of pain relief. Any studies that included treatment performed under general anaesthetic were excluded.

\section{Types of outcome measures}

\section{Primary outcomes}

Presence or absence of pain, as a dichotomous outcome, or the degree of pain, measured by visual analogue scores or categorical scales.

\section{Secondary outcomes}

1. Speed of procedure (in minutes).

2. Blood loss (either in $\mathrm{mL}$ or categorical scale as none, mild or minimal, heavy, troublesome or as dichotomous data).

3. Any moderate or severe adverse effects (dizziness, fainting, shaking, delayed discharge, etc.).

\section{Search methods for identification of studies}

We searched for papers in all languages and translations were undertaken, if necessary.

\section{Electronic searches}

A search strategy was used to identify relevant RCTs.

We searched the Cochrane Gynaecological Cancer Review Group Specialised Register, Cochrane Central Register of Controlled Trials (CENTRAL) (2011, Issue 2), MEDLINE (1950 to May week 2, 2011), EMBASE (1980 to week 20, 2011) for studies of any design relating to analgesia for colposcopic management. The electronic literature search strategies for CENTRAL, MEDLINE and EMBASE are summarised in Appendix 1, Appendix 2 and Appendix 3, respectively.

All relevant articles found were identified on PubMed and using the 'related articles' feature, further searches were carried out for newly published articles.

\section{Searching other resources}

\section{Registries of randomised trials}

We searched the following registries for ongoing trials: Metaregister (www.controlled-trials.com/mrct/), Physicians Data Query (www.ncbi.nlm.nih.gov/), www.clinicaltrials.gov and www.cancer.gov/clinicaltrials.

Conference proceedings and abstracts were searched through ZETOC (http://zetoc.mimas.ac.uk).

\section{Handsearching}

The citation lists of included studies, key textbooks and previous systematic reviews were handsearched.

Reports of conferences were handsearched in the following sources:

- Gynecologic Oncology (Annual Meeting of the American

Society of Gynecologic Oncologist);

- International Journal of Gynecological Cancer (Annual Meeting of the International Gynecologic Cancer Society);

- British Society for Colposcopy and Cervical Cytology (BSCCP) Annual Meeting.

\section{Data collection and analysis}

\section{Selection of studies}

Two review authors $(\mathrm{KG}, \mathrm{AB})$ scanned the titles and abstracts (when available) of all reports identified through the electronic searches. For studies appearing to meet the inclusion criteria, or for which there were insufficient data in the title and abstract to make a clear decision, the full report was obtained. Two review authors $(\mathrm{KG}, \mathrm{AB})$ assessed the full reports obtained from all the electronic and other methods of searching were assessed independently to establish whether the studies met the inclusion criteria or not. Disagreements were resolved by discussion. Where resolution 
was not possible, a third review author (PM-H) was consulted. All studies meeting the inclusion criteria underwent validity assessment and data extraction using a standardised proforma. Studies rejected at this or subsequent stages were recorded in the table of excluded studies, and reasons for exclusion recorded.

\section{Data extraction and management}

Two review authors (KG, $\mathrm{AB}$ ) extracted the data independently using specially designed data extraction forms. The data extraction forms were piloted on several papers and modified as required before use. Any disagreements were discussed and a third review author (PM-H) consulted when necessary. Study authors were contacted for clarification or missing information if necessary. Data were excluded until further clarification was available or if agreement could not be reached.

For included studies, data were abstracted as recommended in Chapter 7 of the Cochrane Handbook for Systematic Reviews of Interventions (Higgins 2011). This included data on the following:

- author, year of publication, country of origin, source of study funding and journal citation (including language);

- setting;

- details of the participants including demographic characteristics (e.g. age, co-morbidities, etc.), total number enrolled and criteria for inclusion and exclusion;

- CIN details at diagnosis;

- details of the type of intervention;

- risk of bias in study (see below);

- duration of follow-up;

- details of the outcomes reported (pain, blood loss, adverse events), including method of assessment, and time intervals (see below):

- for each outcome: outcome definition (with diagnostic criteria if relevant);

$\circ$ unit of measurement (if relevant);

- for scales: upper and lower limits, and whether high or low score is good;

○ results: number of participants allocated to each intervention group;

o for each outcome of interest: sample size; missing participants;

o the time points at which outcomes were collected and reported were noted.

Data on outcomes were extracted as below:

- for dichotomous outcomes (e.g. pain, adverse events), we extracted the number of women in each treatment arm who experienced the outcome of interest and the number of women assessed at endpoint, in order to estimate a risk ratio (RR);

- for continuous outcomes (e.g. blood loss), we extracted the final value and standard deviation (SD) of the outcome of interest and the number of women assessed at endpoint in each treatment arm at the end of follow-up, in order to estimate the mean difference (MD) (if trials measured outcomes on the same scale) or standardised mean differences (if trials measured outcomes on different scales) between treatment arms and its standard error.

Where possible, all data extracted were those relevant to an intention-to-treat (ITT) analysis, in which participants are analysed in groups to which they were assigned.

\section{Assessment of risk of bias in included studies}

The risk of bias in included RCTs was assessed in accordance with guidelines in the Cochrane Handbook for Systematic Reviews of Interventions using the Cochrane Collaboration's tool and the criteria specified in Chapter 8 (Higgins 2011). This included assessment of:

- sequence generation;

- allocation concealment;

- blinding (of participants, healthcare providers and outcome assessors);

- incomplete outcome data:

$\circ$ we recorded the proportion of women whose outcomes were not reported at the end of the study. We coded the satisfactory level of loss to follow-up for each outcome as:

$\diamond$ low risk of bias, if fewer than $20 \%$ of women were lost to follow-up and reasons for loss to follow-up were similar in both treatment arms;

$\diamond$ high risk of bias, if more than $20 \%$ of women were lost to follow-up or reasons for loss to follow-up were different between treatment arms;

$\diamond$ unclear risk of bias, if loss to follow-up was not reported;

- selective reporting of outcomes;

- other possible sources of bias.

Two review authors (KG, $\mathrm{AB}$ ) applied the 'Risk of bias' tool independently and differences were resolved by discussion or by appeal to a third review author (PM-H). Results were summarised in both a 'Risk of bias' graph and a 'Risk of bias' summary. Results of meta-analyses were interpreted with consideration of the findings with respect to risk of bias.

\section{Measures of treatment effect}

We used the following measures of the effect of treatment:

- for dichotomous outcomes, we used the RR;

- for continuous outcomes, we used the MD between treatment arms.

\section{Unit of analysis issues}

Two review authors (KG, $\mathrm{AB}$ ) reviewed any unit of analysis issues according to Higgins 2011 and differences were resolved by discussion. 


\section{Dealing with missing data}

We did not impute missing outcome data for the primary outcome. If data were missing or only imputed data were reported we contacted trial authors to request data on the outcomes only among women who were assessed.

\section{Assessment of heterogeneity}

We assessed heterogeneity between studies by visual inspection of forest plots, by estimation of the percentage heterogeneity between trials that could not be ascribed to sampling variation (Higgins 2003), by a formal statistical test of the significance of the heterogeneity (Deeks 2001) and, when possible, by subgroup analyses. If there was evidence of substantial heterogeneity, we investigated and reported the possible reasons.

\section{Data synthesis}

Each trial was characterised by its type of analgesia and route of administration. Furthermore, the assessment of pain or any other outcomes were classified on whether dichotomous or continuous outcomes were used. Meta-analysis was only performed, when the interventions, route of administration and outcome measures were clinically similar.

- For any dichotomous outcomes, the RR was calculated for each trial and these were then pooled.

- For continuous outcomes, the MDs between the treatment arms at the end of follow-up were pooled if all trials measured the outcome on the same scale, otherwise standardised mean differences were pooled.

If any trials had multiple treatment groups, the 'shared' comparison group was divided into the number of treatment groups and comparisons between each treatment group and the split comparison group was treated as independent comparisons.

Random-effects models with inverse variance weighting were used for all meta-analyses (DerSimonian 1986).

\section{RES U L T S}

\section{Description of studies}

See: Characteristics of included studies; Characteristics of excluded studies.

\section{Results of the search}

The search strategy identified 232 unique references. Two review authors $(\mathrm{KG}, \mathrm{AB})$ read the abstracts of these and articles that obviously did not meet the inclusion criteria were excluded at this stage. Twenty articles were retrieved in full and translated into English where appropriate and updated versions of relevant studies were identified. The full-text screening of these 20 references excluded a further two references for the reasons described in the table Characteristics of excluded studies. However, 18 references reporting on 17 completed RCTs were identified that met our inclusion criteria and are described in the table Characteristics of included studies.

Searches of the grey literature did not identify any additional trials.

\section{Included studies}

The 17 included trials (Al Kurdi 1985; Connell 2000; Crompton 1992; Cruickshank 2005; Diakomanolis 1997; Duncan 2005; Frega 1994; Howells 2000; Johnson 1989; Johnson 1996; Lee 1986; Lipscomb 1995; Mikhail 1988; Rogstad 1992; Sammarco 1993; Sarkar 1993; Winters 2009) randomised 1600 eligible women, of whom 1567 were assessed at the end of the trials (Characteristics of included studies; Table 1)

\section{Design}

All trials were conducted as single centre trials in a colposcopy clinic setting. Various pain relief interventions were reported in the 17 included trials. Two trials (Johnson 1989; Rogstad 1992) investigated cervical injection (intracervical and paracervical block, respectively) with anaesthetic agent (lignocaine 2\%) compared with saline. Three trials (Duncan 2005; Lee 1986; Sammarco 1993) used preparations made up of local anaesthetic plus vasoconstrictor. One of these three trials used cervical injection with lignocaine $1 \%$ mixed with $1: 100,000$ dilution of adrenaline given submucosally and compared it with no treatment (Sammarco 1993), while two other trials (Duncan 2005; Lee 1986) reported cervical injection with a different anaesthetic agent (prilocaine $30 \mathrm{mg} / \mathrm{mL}$ ) mixed with vasoconstrictor (felypressin $0.03 \mathrm{IU} / \mathrm{mL}$ ) compared with no treatment or placebo. Lignocaine $1 \%$ with vasoconstrictor (1:30 of ornipressin in lignocaine $1 \%$ solution) compared to lignocaine $1 \%$ alone was investigated in one trial (Diakomanolis 1997) to evaluate the effects on the blood loss during the procedure.

Three trials investigated the method of cervical injection. In one trial local anaesthetic combined with vasoconstrictor (prilocaine $3 \%$ plus felypressin) administered by deep and superficial injection was compared with deep injection alone (Winters 2009), while in another trial paracervical injection of lignocaine $2 \%$ was compared with direct injection (Johnson 1996). Two different preparations of anaesthetic agent with vasoconstrictor (prilocaine $30 \mathrm{mg} / \mathrm{mL}$ plus felypressin $0.03 \mathrm{IU} / \mathrm{mL}$ compared with lignocaine $2 \%$ plus adrenaline 1:80,000) was investigated in a third trial (Howells 2000).

The use of oral analgesia with NSAID (naproxen sodium, dose 550 $\mathrm{mg}$ ), given half an hour to one hour before treatment, compared 
to placebo or no treatment was reported in two trials (Al Kurdi 1985; Frega 1994) with one trial (Frega 1994) using a single dose of naproxen sodium $550 \mathrm{mg}$ while the other trial (Al Kurdi 1985) used double the dose (1100 mg).

One trial (Cruickshank 2005) used a gas mixture (isoflurane $0.3 \%$ and desflurane $1 \%$ ) as inhalation agent, in addition to standard cervical injection of local anaesthetic plus vasoconstrictor (prilocaine $30 \mathrm{mg} / \mathrm{mL}$ plus felypressin $0.03 \mathrm{IU} / \mathrm{mL}$, also known as octapressin).

A further four trials (Connell 2000; Lipscomb 1995; Mikhail 1988; Sarkar 1993) used topical application of gel, cream and sprays for their anaesthetic effects during the treatment on cervix. One trial looked at the effects of benzocaine 20\% gel (Lipscomb 1995) compared to placebo gel and the other trial compared EMLA cream, which is a local anaesthetic cream consisting of a mixture of lignocaine $2.5 \%$ and prilocaine $2.5 \%$ (Sarkar 1993) to a placebo cream. Mikhail 1988 compared 3 to $4 \mathrm{~mL}$ of a cocaine $10 \%$ spray as a surface anaesthesia to a placebo solution (preservative) for its effects on pain relief. In the trial of Connell 2000, women were randomised to receive either lignocaine hydrochloride $10 \%$ spray or saline in addition to standard cervical infiltration using prilocaine $30 \mathrm{mg} / \mathrm{mL}$ plus felypressin $0.03 \mathrm{IU} / \mathrm{mL}$. TENS, a non-invasive method, was also investigated (Crompton 1992).

\section{Participant characteristics}

The age of the women in the included trials ranged from 17 to 60 years; the mean age across the trials ranged from 27 to 35 years. Both pre- and postmenopausal women were included in the majority of the studies, although two trials (Crompton 1992; Johnson 1989) excluded perimenopausal, postmenopausal women, or both. Other common exclusion criteria were: various allergies, pregnancy and previous treatment to the cervix. Concomitant use of highly protein-bound drug was an exclusion criteria in one trial (Al Kurdi 1985) with oral analgesia using NSAID, while another trial using a gas mixture of isoflurane and desflurane (Cruickshank 2005) excluded women on monoamine-oxidase inhibitors or women driving themselves home from the clinic. Pelvic inflammatory disease, cardiac pacemaker (Crompton 1992), bronchial asthma (Al Kurdi 1985), cardiac conditions, hypertension and epilepsy (Diakomanolis 1997) were other reasons for excluding patients from trials.

Parity was described in patient characteristics for intervention and control group in the Crompton 1992; Cruickshank 2005; Duncan 2005: Howells 2000; Lipscomb 1995 and Johnson 1989 trials. Number of nulliparous women recruited in these trials ranged from $18 \%$ to $48 \%$. Two trials (Lipscomb 1995; Mikhail 1988) reported the number of children, which ranged from no children up to five. Marital status was provided in Duncan 2005, Mikhail 1988 and Sarkar 1993 trials; whereas the usage of contraception was provided in Howells 2000 and Johnson 1989. Sixty-five per cent of women in the intervention group and $72 \%$ in the control group used contraception in the trial of Howells 2000. The use of oral contraceptive pills in Johnson 1989 was $47 \%$ in the intervention group compared to $53 \%$ in the control group.

Cruickshank 2005 used depravation scores, while median anxiety Hospital Anxiety and Depression (HAD) score (Zigmond 1983) and median depression HAD score (Zigmond 1983) was used to compare the characteristics of intervention and control groups in the Crompton 1992 and Johnson 1989 trials. The Johnson 1989 trial also used anxiety visual analogue score (Zigmond 1983) and premenstrual syndrome scores (no reference provided). Anxiety score (Spielberger 1970) was also used in the trial of Lee 1986. Only one trial (Howells 2000) compared the groups for smoking status.

Two trials (Howells 2000; Winters 2009) reported smear grades as well as final histology with CIN grades. Lipscomb 1995 and Winters 2009 reported positive margins of excised cervical specimen after treatment. The size of the cervical pre-invasive lesion was reported in patients' characteristics by Crompton 1992, while Howells 2000 reported the size of the loop excised. Passes of loop diathermy were provided by Howells 2000 with $76 \%$ in the intervention group and $75 \%$ in the control group having one pass of the loop. Lipscomb 1995 reported average number of loop passes per person in trial and control group.

In nine of the 17 trials, women underwent laser ablation of cervix (Al Kurdi 1985; Crompton 1992; Diakomanolis 1997; Frega 1994; Johnson 1989; Johnson 1996; Lee 1986; Mikhail 1988; Sarkar 1993), in five trials LLETZ was used (Cruickshank 2005; Howells 2000; Lipscomb 1995; Winters 2009; Connell 2000), cryotherapy in one trial (Sammarco 1993) and in two trials cold coagulation with Semm Coagulator was used to treat the cervix (Duncan 2005; Rogstad 1992).

\section{Outcomes}

The diverse nature of the interventions in the trials precluded direct comparison apart from two trials (Al Kurdi 1985; Frega 1994) comparing oral analgesia versus control, it was possible to combine the pain relief outcome reported on visual analogue scale (VAS).

\section{Pain relief reported on visual analogue scale (VAS)}

For the included studies, the degree of pain relief during the procedure was reported as VAS in 13 trials (Al Kurdi 1985; Connell 2000; Cruickshank 2005; Frega 1994; Johnson 1989; Johnson 1996; Lee 1986; Lipscomb 1995; Mikhail 1988; Rogstad 1992; Sammarco 1993; Sarkar 1993; Winters 2009). In all trials VAS scores were assessed immediately after the procedure. Five trials (Al Kurdi 1985; Cruickshank 2005; Lipscomb 1995; Sarkar 1993; Winters 2009) used a $100-\mathrm{mm}$ or $10-\mathrm{cm}$ linear analogue scale, where 0 was no pain at all and 100 (or 10 in the $10-\mathrm{cm}$ scale) was 
worst pain imaginable. One trial (Johnson 1989) reported pain relief on $120-\mathrm{mm}$ visual linear analogue scale, which was converted to percentages. Johnson 1996 and Connell 2000 reported pain relief as VAS; however, the values were median and interquartile range, rather than mean and SD. Sammarco 1993 reported VAS on an 11-point scale ( 0 to 10 ) where 0 was no pain and 10 was severe pain.

\section{Pain relief reported on verbal rating scores (VRS)}

In five trials (Al Kurdi 1985; Diakomanolis 1997; Duncan 2005; Lee 1986; Mikhail 1988), pain relief was reported on VRS categorised as none, mild, moderate or severe.

\section{Pain relief reported on other categorical scales}

In addition to VAS, Johnson 1989 and Johnson 1996 also reported pain relief as an objective score, given by the attending nurse and laser operator on a categorical scale of 0 to 2 . In another trial (Howells 2000), pain was scored by the attending colposcopist on a categorical scale $(0=$ none to $4=$ severe $)$ as well as by women undergoing treatment $(0=$ none to $5=$ unbearable). In the Sarkar 1993 trial, pain scores were measured for pain relief after treatment and not just during treatment. However, the time scale for carrying out the pain score was not specified. In the trial of Al Kurdi 1985, women were asked whether additional pain killers were required within the first 24 hours. In Cruickshank 2005 trial, women were asked whether additional pain relief was required after treatment. It would appear that this was asked at six months' follow-up, which carries a risk of recall bias. Owing to this risk, these data were not included in the analysis.

\section{Blood loss during treatment}

Blood loss was reported as none, mild, moderate and troublesome in seven trials (Crompton 1992; Cruickshank 2005; Diakomanolis 1997; Howells 2000; Lee 1986; Mikhail 1988; Sarkar 1993). In the Diakomanolis 1997 trial, the method of measuring blood loss was explicitly specified, while other trials (Crompton 1992; Cruickshank 2005; Howells 2000; Lee 1986; Mikhail 1988; Sarkar 1993) reported blood loss subjectively as scored by the operator on a categorical scale ( $0=$ none to $5=$ heavy/troublesome) .

\section{Speed of procedure (or duration of treatment)}

Speed of procedure was reported in four trials (Diakomanolis 1997; Howells 2000; Lee 1986; Sarkar 1993).

\section{Anxiety}

Preoperative anxiety is one of the most significant risk factors for experiencing pain during cervical colposcopy treatment (Johnson 1994). In four trials anxiety levels were measured preoperatively in both arms. Anxiety was measured using HAD scores in three trials (Crompton 1992; Cruickshank 2005; Johnson 1989), while a fourth trial (Lee 1986) used a different scale (Spielberger State Anxiety Inventory) (Spielberger 1970).

\section{Excluded studies}

Two references were excluded, after obtaining the full text, for the following reasons:

- The trial of Sarkar 1990 was excluded as it was not an RCT and it was not controlled for placebo effects. This trial reported use of EMLA cream (lignocaine-prilocaine cream) for pain relief during cervical laser treatment;

- Sharp 2009 was excluded because this study did not compare pain relief interventions. This was an observational study nested within an RCT in which women completed questionnaire about their experiences at colposcopy, colposcopy and biopsy, and colposcopy and LLETZ treatment.

For further details of all the excluded studies see the Characteristics of excluded studies table.

\section{Risk of bias in included studies}

Five trials (Connell 2000; Cruickshank 2005; Johnson 1989; Johnson 1996; Mikhail 1988) were at low risk of bias, as they satisfied at least five of the criteria that we used to assess risk of bias. Eight trials (Al Kurdi 1985; Diakomanolis 1997; Duncan 2005; Howells 2000; Lee 1986; Lipscomb 1995; Sarkar 1993; Winters 2009) were at moderate risk of bias as they satisfied three or four of the criteria. The trial of Rogstad 1992 was at high risk of bias as it only satisfied two of the criteria and a further three trials (Crompton 1992; Frega 1994; Sammarco 1993) were also at high risk of bias as they only satisfied one criterion (see Figure 1; Figure 2). 
Figure I. 'Risk of bias' graph: review authors' judgements about each 'Risk of bias' item presented as percentages across all included studies.

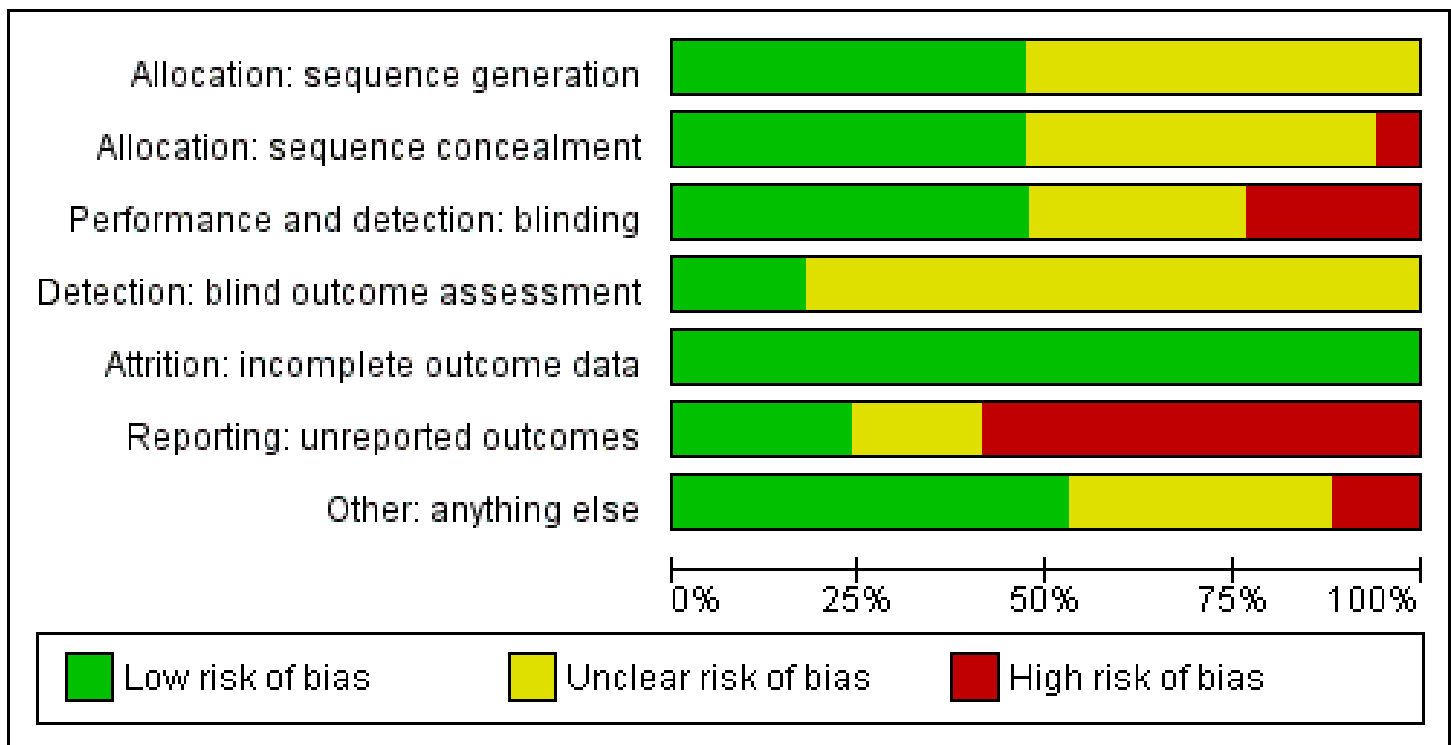


Figure 2. 'Risk of bias' summary: review authors' judgements about each 'Risk of bias' item for each included study.

\begin{tabular}{|c|c|c|c|c|c|c|c|}
\hline & 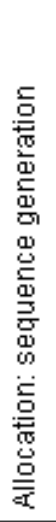 & 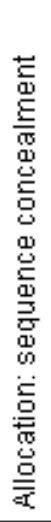 & 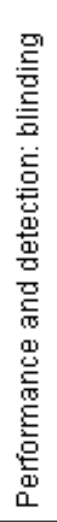 & 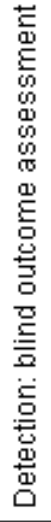 & 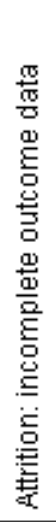 & 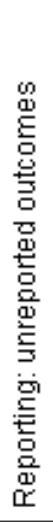 & 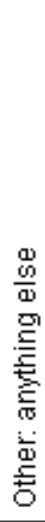 \\
\hline Al Kurdi 1985 & $?$ & $?$ & $?$ & $?$ & + & & + \\
\hline Connell 2000 & + & + & + & $?$ & + & & \\
\hline Crompton 1992 & $?$ & & & $?$ & + & $?$ & $?$ \\
\hline Cruickshank 2005 & + & + & + & + & + & & \\
\hline Diakomanolis 1997 & $?$ & + & + & $?$ & + & & ? \\
\hline Duncan 2005 & $?$ & + & $?$ & $?$ & + & & \\
\hline Frega 1994 & $?$ & $?$ & $?$ & $?$ & + & & $?$ \\
\hline Howells 2000 & $?$ & + & & $?$ & + & & \\
\hline Johnson 1989 & + & + & + & + & + & & \\
\hline Johnson 1996 & + & + & + & + & + & & $?$ \\
\hline Lee 1986 & ? & $?$ & $?$ & $?$ & + & & $?$ \\
\hline Lipscomb 1995 & + & $?$ & + & $?$ & + & $?$ & \\
\hline Mikhail 1988 & + & $?$ & + & $?$ & + & & \\
\hline Rogstad 1992 & + & ? & $?$ & ? & + & & ? \\
\hline Sammarco 1993 & $?$ & $?$ & & $?$ & + & $?$ & \\
\hline Sarkar 1993 & $?$ & $?$ & 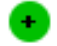 & $?$ & + & & \\
\hline Winters 2009 & + & + & & $?$ & + & & + \\
\hline
\end{tabular}


Eight trials (Connell 2000; Cruickshank 2005; Johnson 1989; Johnson 1996; Lipscomb 1995; Mikhail 1988; Rogstad 1992; Winters 2009) reported the method of generation of the sequence of random numbers used to allocate women to treatment arms, but three of these trials (Lipscomb 1995; Mikhail 1988; Rogstad 1992) did not report concealment of this allocation sequence from patients and healthcare professionals involved in the trial. Five trials (Al Kurdi 1985; Connell 2000; Frega 1994; Lee 1986; Sammarco 1993; Sarkar 1993) did not report on either the method of sequence generation or concealment of allocation. In the trials of Duncan 2005 and Howells 2000 it was unclear whether the method of assigning women to treatment groups was carried out using an adequate method of sequence generation, but the allocation was adequately concealed. The trial of Crompton 1992 did not report sequence generation details but did state that the allocation was not concealed. Three trials (Cruickshank 2005; Johnson 1989; Johnson 1996) reported blinding of patients, healthcare professionals and outcome assessors, whereas this information was not reported in five trials (Al Kurdi 1985; Duncan 2005; Frega 1994; Lee 1986; Rogstad 1992). Five trials (Connell 2000; Diakomanolis 1997; Lipscomb 1995; Mikhail 1988; Sarkar 1993) confirmed blinding of patients and healthcare professionals, but it was unclear whether the outcome assessor was blinded and a further four trials (Crompton 1992; Howells 2000; Sammarco 1993; Winters 2009) confirmed that at least one of patients and health care professionals were not blinded but did not report whether the outcome assessor was blinded or not. It was not certain whether three trials (Crompton 1992; Lipscomb 1995; Sammarco 1993) reported all the outcomes that they assessed, but in 10 trials (Connell 2000; Cruickshank 2005; Diakomanolis 1997; Duncan 2005; Frega 1994; Howells 2000; Johnson 1989; Johnson 1996; Rogstad 1992; Winters 2009) it appeared that additional pertinent outcomes should have been reported and their omission left a gap in the evidence. The remaining four trials seemed to report all relevant outcomes related to the subject matter. No other form of bias appeared likely in 10 trials (Al Kurdi 1985; Connell 2000; Cruickshank 2005; Duncan 2005; Howells 2000; Johnson 1989; Lee 1986; Lipscomb 1995; Mikhail 1988; Winters 2009). Additional forms of bias seemed a possibility in the trials of Sammarco 1993 and Sarkar 1993 in the way some analyses were undertaken, but it was unclear whether this was the case in the remaining five trials. At least $80 \%$ of women who were enrolled were assessed at endpoint in all 17 trials.

\section{Effects of interventions}

\section{Local anaesthetic (lignocaine $2 \%$ ) versus placebo (saline injection)}

\section{Pain scores during procedure (VAS)}

Two trials (Johnson 1989; Rogstad 1992) compared the effects of local anaesthetic lignocaine $2 \%$ without a vasoconstrictor to placebo (saline injection). The trial of Johnson 1989 used lignocaine $2 \%$ injection for paracervical block while the trial of Rogstad 1992 used lignocaine $2 \%$ for direct injection in the cervix. The trial of Rogstad 1992 found that women who received local anaesthetic had significantly less pain during treatment than women who received saline injection (60 women; MD -24.00; 95\% CI 35.44 to -12.56), whereas the Johnson 1989 trial found no statistically significant difference between the same groups (70 women; MD -3.00; 95\% CI -16.03 to 10.03 ) (Analysis 1.1).

\section{Moderate to severe pain during procedure}

The trial of Rogstad 1992 found that women who received local anaesthetic reported significantly less moderate or severe pain during treatment than women who received control (RR 0.36; $95 \%$ CI 0.18 to 0.71 ) (Analysis 1.2).

\section{Local anaesthetic plus vasoconstrictor versus control}

Three trials (Duncan 2005; Lee 1986; Sammarco 1993) reported comparisons of local anaesthetic with vasoconstrictor versus control, but variations in both the interventions or control groups, or both, meant that the trials were unable to be pooled in a metaanalysis.

\section{Pain scores during procedure}

Meta-analysis of two trials (Lee 1986; Sammarco 1993), assessing 95 women, found that women who received local anaesthetic with vasoconstrictor (prilocaine 3\% with felypressin $0.03 \mathrm{IU} / \mathrm{mL}$ and lignocaine $1 \%$ with adrenaline 1:100,000 dilution in the trials of Lee 1986 and Sammarco 1993, respectively) had significantly less pain during treatment than women who received no treatment (MD -23.73; 95\% CI -37.53 to -9.93) (Analysis 2.1). The percentage of the variability in effect estimates that is because of heterogeneity rather than chance may represent substantial heterogeneity $\left(\mathrm{I}^{2}=63 \%\right)$. In trial of Sammarco 1993 women in both intervention arm and control arm received oral analgesic ketoprofen $75 \mathrm{mg}$ single dose within one hour of receiving treatment.

\section{Moderate or severe pain during procedure}

Two trials (Duncan 2005; Lee 1986) reporting pain relief with local anaesthetic plus vasoconstrictor versus control using VRS showed contrasting results. The trial of Duncan 2005 found that women who received local anaesthetic with vasoconstrictor $(5-\mathrm{mL}$ 
vials of prilocaine $3 \%(30 \mathrm{mg} / \mathrm{mL})$ with felypressin $0.03 \mathrm{IU} / \mathrm{mL})$ reported significantly less moderate or severe pain during treatment than women who received placebo. The Lee 1986 trial found no statistically significant difference in the same outcome between women who received vasoconstrictor with local anaesthetic $(2 \mathrm{~mL}$ of prilocaine $3 \%$ with felypressin $0.03 \mathrm{IU} / \mathrm{mL}$ ) and those who received no treatment (RR 0.12; 95\% CI 0.04 to 0.37 and RR 0.73 ; $95 \%$ CI 0.42 to 1.27 (Analysis 2.2) for local anaesthetic with vasoconstrictor versus placebo or no treatment, respectively). Whether the difference could be attributable to varying dosage of anaesthetic agents $(5 \mathrm{~mL}$ in Duncan 2005 trial versus $2 \mathrm{~mL}$ in Lee 1986 trial) is worth considering. No other trials on optimal dosage have been identified to address this issue. Also of note, the method of cervical treatment differed in these two trials. Women in Lee 1986 received cervical treatment with laser vaporisation while in Duncan 2005 trial the women received treatment with Semm coagulator (high-temperature electro-cautery).

\section{Haemorrhage (subjective blood loss) during procedure}

The trial of Lee 1986 found no statistically significant difference in the risk of troublesome bleeding between women who received local anaesthetic with vasoconstrictor $(2 \mathrm{~mL}$ of prilocaine $3 \%$ with $0.03 \mathrm{IU} / \mathrm{mL}$ of felypressin $0.03 \mathrm{IU} / \mathrm{mL}$ ) and those who received no treatment (RR 0.40; 95\% CI 0.09 to 1.87 ) (Analysis 2.3). However, the blood loss was not measured and was a subjective impression by the operator.

\section{Local anaesthetic plus vasoconstrictor versus local anaesthetic injection alone}

\section{Moderate or severe pain during procedure}

The trial of Diakomanolis 1997 found no statistically significant difference in the risk of moderate or severe pain between women who received local anaesthetic with vasoconstrictor $(30 \mathrm{~mL}$ of a $1: 30$ ornipressin-lignocaine $1 \%$ solution) and those who received local anaesthetic (30 $\mathrm{mL}$ of lignocaine $1 \%$ solution) alone (RR 1.20; $95 \%$ CI 0.57 to 2.52 ) (Analysis 3.1).

\section{Haemorrhage (measured blood loss) during procedure}

The trial of Diakomanolis 1997 found that women who received vasoconstrictor (ornipressin 1:30) with local anaesthetic $(30 \mathrm{~mL}$ of lignocaine $1 \%$ ) had significantly less measured blood loss during treatment than women who received local anaesthetic $(30 \mathrm{~mL}$ of lignocaine 1\%) alone (MD -8.75; 95\% CI -10.43 to -7.07) (Analysis 3.2). In this trial the amount of solution used for cervical injection of $30 \mathrm{~mL}$ is higher than what is generally used. Unlike the subjective evaluation of blood loss in other trials by the operator, trial of Diakomanolis 1997 reported the actual measured volume of blood loss.

\section{Speed of procedure (duration of treatment)}

The trial of Diakomanolis 1997 found that duration of treatment was significantly less in women who received vasoconstrictor with local anaesthetic (30 mL of a 1:30 ornipressin with lignocaine $1 \%$ ) than women who received control (30 $\mathrm{mL}$ of lignocaine $1 \%$ ) (MD -7.72 ; 95\% CI -8.49 to -6.95) (Analysis 3.3).

\section{Local anaesthetic plus vasoconstrictor (prilocaine (local anaesthetic) with felypressin (vasoconstrictor) versus lignocaine (local anaesthetic) with adrenaline (vasoconstrictor))}

The trial of Howells 2000 compared two types of local anaesthetic with vasoconstrictor. More specifically, it reported a comparison of prilocaine $3 \%$ with felypressin $0.03 \mathrm{IU} / \mathrm{mL}$ versus lignocaine $2 \%$ with adrenaline 1:80,000.

\section{Pain scores during procedure (using 6-point categorical scale)}

The trial found no statistically significant difference in pain scores when measured using a 6-point categorical scale between women who received prilocaine and felypressin and those who received lignocaine and adrenaline (MD $-0.05 ; 95 \% \mathrm{CI}-0.26$ to 0.16 ) (Analysis 4.1).

\section{Blood loss during procedure}

The trial found that women who received prilocaine and felypressin had more mean blood loss during treatment than women who received lignocaine and adrenaline (MD 0.41; 95\% CI 0.13 to 0.69 ) (Analysis 4.2). However, the observed difference is unlikely to be clinically significant and the assessment of blood loss was by subjective scoring and not the actual measured loss.

\section{Deep plus superficial versus deep cervical injection}

\section{Pain scores during procedure (VAS: 0 to 100 )}

The trial of Winters 2009 found no statistically significant difference in pain scores when measured using a VAS between women who received deep and superficial injection and those who received deep cervical injection (MD -4.90; 95\% CI -11.51 to 1.71) (Analysis 5.1).

\section{Oral analgesic versus placebo or no treatment}

Two trials (Al Kurdi 1985; Frega 1994) reported a comparison of naproxen sodium $550 \mathrm{mg}$ tablets given at least 30 minutes before treatment (oral analgesic) versus placebo. The trial of Frega 1994 also included a third arm, which had randomised women to no drug. 


\section{Pain scores during procedure}

Meta-analysis of the two trials (Al Kurdi 1985; Frega 1994), assessing 129 women, found no statistically significant difference in pain scores when measured using a VAS between women who received oral analgesic and those who received placebo (MD -3.51; 95\% CI -10.03 to 3.01 (Analysis 6.1). The percentage of the variability in effect estimates that is because of heterogeneity rather than sampling error (chance) was not important $\left(\mathrm{I}^{2}=0 \%\right)$. The trial of Frega 1994 also found no significant difference in pain scores between oral analgesic versus no treatment (MD -4.00; 95\% CI 13.69 to 5.69 (Analysis 6.1).

\section{Moderate to severe pain during procedure}

The trial of Al Kurdi 1985 found no statistically significant difference in the moderate or severe pain experienced during treatment between women who received oral analgesic and those who received placebo (RR 0.82; 95\% CI 0.60 to 1.13) (Analysis 6.2).

\section{Pain relief required in first $\mathbf{2 4}$ hours}

The trial of Al Kurdi 1985 found that women who received oral analgesic for pain relief during colposcopy were significantly less likely to use additional pain relief within the first 24 hours following treatment than women who received placebo (RR 0.12; $95 \%$ CI 0.03 to 0.47 ) (Analysis 6.3).

\section{Inhalation analgesia versus placebo or no treatment}

The trial of Cruickshank 2005 reported a comparison of a gas mixture (isoflurane and desflurane) as inhalation analgesia versus placebo (air).

\section{Pain scores during procedure}

Cruickshank 2005 found that women who received trial gas mixture for pain relief (in addition to standard cervical injection with prilocaine $30 \mathrm{mg} / \mathrm{mL}$ plus felypressin $0.03 \mathrm{IU} / \mathrm{mL}$ ) had significantly less pain during treatment than women who received placebo (MD -7.20; 95\% CI -12.45 to -1.95) (Analysis 7.1).

\section{Haemorrhage during procedure}

Cruickshank 2005 found no statistically significant difference in the risk of heavy vaginal bleeding between women who received gas mixture and those who received placebo (RR 1.17; 95\% CI 0.83 to 1.64 ) (Analysis 7.2).

\section{Anxiety (HAD score) during procedure}

Cruickshank 20051 found no statistically significant difference in anxiety scores between women who received gas mixture and those who received placebo (MD 0.01; 95\% CI - 0.80 to 0.82) (Analysis 7.3).

\section{Topical application versus placebo}

Four trials (Connell 2000; Lipscomb 1995; Mikhail 1988; Sarkar 1993) reported comparisons of anaesthetic topical application versus placebo, but variations in the interventions meant that the trials were unable to be pooled in meta-analysis.

\section{Pain scores during procedure}

The trial of Lipscomb 1995 found no statistically significant difference in pain scores when measured using a VAS between women who received anaesthetic topical application ( $20 \%$ benzocaine gel) and those who received placebo (MD -9.00; 95\% CI -68.59 to 50.59) (Analysis 8.1). Women in both intervention and placebo arm received preprocedure oral analgesia in addition to injecting a total of $4 \mathrm{~mL}$ of lignocaine $1 \%$ (mixed with adrenaline $1: 100,000$ ) in four quadrants of the cervix.

\section{Speed of procedure (duration of treatment)}

The trial of Sarkar 1993 found no statistically significant difference in the duration of treatment between women who received anaesthetic topical application (EMLA cream - mixture of lignocaine $2.5 \%$ and prilocaine $2.5 \%$ ) and those who received placebo (MD 0.10; 95\% CI -1.38 to 1.58) (Analysis 8.2).

\section{Cocaine spray versus placebo}

The trial of Mikhail 1988 reported a comparison of cocaine spray versus placebo.

\section{Pain scores during procedure (VAS: 0 to 100)}

The Mikhail 1988 trial found that women who received cocaine spray for pain relief had significantly less pain during treatment than women who received placebo (MD -28.00; 95\% CI -37.86 to -18.14) (Analysis 9.1).

\section{Moderate to severe pain during procedure}

The Mikhail 1988 trial found that women who received cocaine spray experienced significantly less moderate or severe pain during treatment than women who received placebo (RR 0.57; 95\% CI 0.37 to 0.89 ) (Analysis 9.2). 


\section{Haemorrhage during procedure (troublesome bleeding)}

The Mikhail 1988 trial found that women who received cocaine spray had significantly less risk of troublesome bleeding following treatment than women who received placebo. No women in the cocaine spray arm and 11 out of 25 in the placebo arm had troublesome bleeding. We did not calculate the RR; the default zerocell correction within RevMan would bias the result of the metaanalysis towards no difference between cocaine spray and placebo (Analysis 9.3).

\section{TENS, local anaesthetic and TENS plus local anaesthetic injection}

The trial of Crompton 1992 reported comparison of TENS, TENS plus cervical infiltration with local anaesthetic with a vasoconstrictor ( $2 \mathrm{~mL}$ of lignocaine $2 \%$ plus octapressin) injection and local anaesthetic injection alone. As results of pain relief were reported as median with interquartile range, they were not included in analysis but were summarised separately.

\section{Troublesome blood loss during procedure}

The Crompton 1992 trial found no statistically significant difference in the risk of troublesome vaginal bleeding between women who received TENS, TENS plus local anaesthetic and local anaesthetic alone (RR 2.56; 95\% CI 0.28 to 23.29 ; RR 0.77; $95 \%$ CI 0.19 to 3.20 and RR 0.30 ; $95 \%$ CI 0.04 to 2.55 for comparisons of TENS versus TENS plus local anaesthetic, TENS versus local anaesthetic alone and TENS plus local anaesthetic versus local anaesthetic alone, respectively) (Analysis 10.1; Analysis 11.1; Analysis 12.1).

\section{Studies and analyses included within the review but not in the forest plots}

\section{Pain scores (VAS and objective pain scores)}

The trials of Connell 2000; Crompton 1992; and Johnson 1996 reported pain scores on VAS scales using median and interquartile range. The trial of Johnson 1996 also reported objective pain scores by attending nurse and colposcopist.

\section{Lignocaine spray versus placebo}

The trial of Connell 2000 comparing $0.5 \mathrm{~mL}$ of lignocaine $10 \%$ spray in addition to standard cervical infiltration with prilocaine $30 \mathrm{mg} / \mathrm{mL}$ plus felypressin $0.03 \mathrm{IU} / \mathrm{mL}$ versus placebo. The trial reported the results of pain relief using a VAS scale as median and interquartile range. The results showed that application of lignocaine spray had no significant effect on pain scores $(\mathrm{P}=0.38)$. The medians with interquartile range of the VAS scale for lignocaine spray versus placebo were 40.0 (21.25 to 63.25) and 36.0 (17.5 to 49.5), respectively.

TENS, local anaesthetic injection and TENS plus local anaesthetic injection

The trial of Crompton 1992 reported comparison of TENS, TENS plus cervical infiltration with $2 \mathrm{~mL}$ of lignocaine $2 \%$ plus octapressin and cervical infiltration with cervical infiltration with $2 \mathrm{~mL}$ of lignocaine $2 \%$ plus octapressin alone.

The results of pain relief using VAS were reported as median pain scores and interquartile range (24 (10 to 42$), 17$ (7 to 30$)$ and 18(8 to 31) for TENS, local anaesthetic and TENS plus local anaesthetic, respectively). The median pain score for the group assigned TENS only was higher than the median score for the group given direct infiltration of local anaesthetic $(\mathrm{U}=-1.57 ; \mathrm{P}=$ $0.12)$.

\section{Paracervical versus intracervical injection in the transformation zone (TZ) of cervix with lignocaine}

The trial of Johnson 1996 compared direct infiltration in the TZ with $2 \mathrm{~mL}$ of lignocaine $2 \%$ versus paracervical block with lignocaine $2 \%$ using $5 \mathrm{~mL}$ on each side of the cervix. This trial reported pain relief on a VAS expressing in median and interquartile ranges. The median linear analogue pain scores (interquartile range) for direct infiltration and paracervical blocks were $14 \%$ (6\% to $29 \%)$ and $30 \%(21 \%$ to $47 \%$ ), respectively (Mann-Whitney $\mathrm{Z}=2.79$; $\mathrm{P}=0.005)$ suggesting direct infiltration was associated with lower pain scores. The trial also reported objective pain scores as scored by attending nurse and colposcopist. The objective pain score for direct injection with local anaesthetic was slightly lower (23 women; 0 ( 0 to 0.25$)$ ) than the score associated with paracervical lignocaine injection (21 women; 0 (0 to -0.75 ); Mann-Whitney test $\mathrm{Z}=0.23 ; \mathrm{P}=0.8)$.

\section{I SCUSSION}

\section{Summary of main results}

Seventeen RCTs (1567 women) met the inclusion criteria and were assessed in the review. These trials compared a variety of interventions aimed at reducing pain in women who underwent treatment for CIN in colposcopy clinic settings, including cervical injection with lignocaine alone, lignocaine with adrenaline, prilocaine with felypressin, oral analgesics (NSAID), inhalation analgesia (gas mixture of isoflurane and desflurane), lignocaine spray, cocaine spray, local application of benzocaine $20 \%$ gel, EMLA cream and TENS. 
Use of lignocaine $2 \%$ for cervical injection (as direct injection or paracervical block) showed no overall benefit in pain relief as compared to placebo, with one trial (Rogstad 1992) showing a beneficial effect while another trial (Johnson 1989) found no benefit. Use of the local anaesthetic prilocaine with a vasoconstrictor (felypressin) showed significant reduction in pain on VAS (Duncan 2005; Lee 1986). However, one trial (Lee 1986) found no benefit when the pain was assessed with VRS. This trial also reported no reduction in blood loss with prilocaine plus felypressin. However, the blood loss was not measured and it was the subjective impression of the operator. It is also worth noting that this trial (Lee 1986), though randomised, was not a double-blind controlled trial and only had a small sample size ( 25 in the intervention arm and 25 in the placebo arm). The addition of a vasoconstrictor agent (ornipressin) to anaesthetic agent (lignocaine 1\%) resulted in significantly less measured blood loss and reduction of the duration of procedure (Diakomanolis 1997). Direct cervical injection with local anaesthetic (lignocaine $2 \%$ ) resulted in better pain relief than placebo (Rogstad 1992) and paracervical block (Johnson 1996). Superficial injection of local anaesthetic in the cervix before deep injection did not result in any better pain relief (Winters 2009). Oral analgesia with an NSAID before the procedure did not result in better pain relief, although one trial (Al Kurdi 1985) reported that the women were significantly less likely to use oral analgesics at home within the first 24 hours of treatment.

Inhalation of gas mixture (isoflurane and desflurane) in addition to standard cervical injection with prilocaine $30 \mathrm{mg} / \mathrm{mL}$ plus felypressin $0.03 \mathrm{IU} / \mathrm{mL}$ resulted in significantly less pain during the LLETZ procedure with no effect on blood loss or HAD anxiety scores (Cruickshank 2005).

EMLA local anaesthetic cream did not result in better pain relief compared to placebo (Sarkar 1993). Spraying of the cervix with cocaine spray before treatment resulted in better pain relief and less troublesome bleeding (Mikhail 1988). Use of topical gel (benzocaine 20\%) (Lipscomb 1995) or lignocaine spray in addition to standard cervical injection prilocaine $30 \mathrm{mg} / \mathrm{mL}$ plus felypressin $0.03 \mathrm{IU} / \mathrm{mL}$ did not result in any benefit (Connell 2000).

On comparison of different preparations of local anaesthetic mixed with vasoconstrictor, prilocaine with felypressin did not differ from lignocaine with adrenaline for its effect on pain control (Howells 2000). Mean observed blood loss was less in the lignocaine with adrenaline group compared with prilocaine with felypressin group, although the difference was not clinically significant.

The use of TENS on its own or combined with local anaesthetic injection during cervical laser therapy did not appear to be of any benefit (Crompton 1992).

No serious side effects were noticed in the trials reporting these outcomes. The reported side effects were feeling faint, shaking, dizziness, abdominal cramps, sweating, feeling hot, weakness, and moderate, transient hypertension. Prilocaine with felypressin caused fewer side effects (mainly shaking and fainting) than lignocaine with adrenaline in one trial (Howells 2000).

\section{Overall completeness and applicability of evidence}

This review consists of many single trial analyses of small numbers of women, which limits the conclusions that can be drawn. Some of the trials included use of more than one type of pain relief intervention such as preoperative oral analgesics in addition to cervical infiltration. In modern day colposcopy practice, commonly used interventions for pain relief are local anaesthetic infiltration with vasopressin followed by large loop excision of the cervix, cryotherapy, laser ablation or conisation with a knife. In order to improve quantification of the benefits of these interventions in relief of pain and other symptoms (blood loss, etc.) without significant side effects, larger RCTs are required.

\section{Measurement of pain}

Several validated scales were used for the measurement of pain in the trials included within the review, which may influence the accuracy of the outcome as complexity of the rating task for the measure influences the sensitivity and specificity. It is thought that a VAS reflects pain experienced during operative procedures more accurately (Huskisson 1983). VAS were used to report pain relief in 13 of the included trials (Al Kurdi 1985; Connell 2000; Cruickshank 2005; Frega 1994; Johnson 1989; Johnson 1996; Lee 1986; Lipscomb 1995; Mikhail 1988; Rogstad 1992; Sammarco 1993; Sarkar 1993; Winters 2009). Sammarco 1993 reported VAS using an 11-point scale. In addition to VAS, two trials (Johnson 1989; Johnson 1996) also reported pain relief as an objective score given by the attending nurse and laser operator on a categorical scale of 0 to 2. In the other trial (Howells 2000), pain was scored by the attending colposcopist on a categorical scale ( 0 to 4 ) as well as by women undergoing treatment (0 to 5). Sarkar 1993 reported pain utilising McGill's pain questionnaire, on a categorical scale to grade pain, cramp and backache caused by the laser treatment. In five trials (Al Kurdi 1985; Diakomanolis 1997; Duncan 2005; Lee 1986; Mikhail 1988) pain relief was reported on VRS categorised as none, mild, moderate or severe.

An element of under reporting has been demonstrated, especially where specific mean and SDs have not been stated. Several trials reported pain as a graphical representation without numerical values, which is a form of under reporting. Such selective outcome reporting must be taken into consideration when interpreting the results. The trials of Johnson 1996, Connell 2000 and Sarkar 1993 reported pain relief as VAS, but the values were median and interquartile range rather than mean and SD and therefore these data could not be converted to mean pain scores. In four trials (Frega 1994; Lee 1986; Mikhail 1988; Rogstad 1992), pain relief outcomes were reported as a graphical representation that required calculation of mean and SD. In three trials (Frega 1994; Mikhail 1988; Lee 1986), graphical representation of data was without numerical values. The major limitation of the review and interpretation of the results is the presence of selective outcome reporting. 


\section{Quality of the evidence}

This review incorporates evidence from 17 RCTs that assessed 1567 women in total. Effective pain relief from local anaesthesia is dependent on various factors, including route of administration, concentration and classification of drug, and the time interval between the administration of the analgesic and start of the procedure. These factors differed between the trials. This review was unable to establish the time interval between administration of injection and start of the procedure from the trial data.

Owing to the heterogeneity of the outcomes and treatments considered, there are many single trial analyses and limited consistent data available to carry out comparisons between trials. The majority of the included trials were underpowered to demonstrate a significant effect and some trials did not include a power calculation in their methodologies. As the majority of comparisons relied on single trials that were underpowered, the treatment effects should ideally be examined by conducting further studies.

\section{Potential biases in the review process}

A comprehensive search was performed, including electronic databases and a thorough search of the grey literature. All references were sifted and data extracted by two review authors independently. We restricted the included studies to RCTs as they provide the strongest level of evidence available. Hence, we have attempted to reduce bias in the review process.

The greatest threat to the validity of the review is likely to be the possibility of publication bias (i.e. studies that did not find the treatments to have been effective may not have been published). We were unable to assess this possibility as the meta-analyses included a limited number of the included trials (two out of 17 included trials).

\section{Agreements and disagreements with other studies or reviews}

These found no other systematic reviews in this field and we did not identify any other retrospective controlled studies using these outcomes.

\section{AUTHORS' CONCLUSIONS}

\section{Implications for practice}

Oral analgesia, EMLA cream, TENS, lignocaine spray or benzocaine gel did not provide any benefit in pain relief during cervical colposcopy treatment. Spraying of cervix with cocaine spray before treatment resulted in better pain relief and also less troublesome bleeding. Local anaesthetic agent combined with a vasoconstrictor agent resulted in better pain control compared with placebo and was associated with significantly less blood loss. Mean observed blood loss score was less with lignocaine plus adrenaline as compared with prilocaine plus felypressin, although the difference was not clinically significant. Direct cervical injection of local anaesthetic with a vasoconstrictor agent resulted in reduction in pain scores during treatment and should be considered for all cervical colposcopy treatment for CIN. However, no conclusions can be drawn with regards to optimum number of sites to inject in the cervix, depth of injection in the cervix (superficial, deep, or both) and dosage of the agent used. In terms of side effects, combination of prilocaine with felypressin caused fewer side effects than lignocaine with adrenaline. Inhalation of gas mixture in addition to standard pain relief injection appears to have additional pain relief benefit. In routine clinical practice, intracervical injection of analgesic with a vasoconstrictor, particularly those related to vasopressin, appeared to be the optimum analgesia for treatment.

\section{Implications for research}

Oral analgesia and the individual topical agents such as EMLA cream, lignocaine spray or benzocaine gel appeared to provide little benefit over placebo or no treatment for pain relief during colposcopy. However, this evidence comes from small trials with methodological shortcomings, therefore we consider this evidence to be of a low quality.

Further available evidence suggests that a local anaesthetic combined with a vasoconstrictor agent significantly reduces pain and measured blood loss, therefore this treatment should be offered to women undergoing colposcopy. This evidence is of moderate quality and further research will have an important impact on our confidence in these findings.

Further high-quality, adequately powered trials should be undertaken in order to provide the data necessary to estimate the optimal route of administration and dose of local anaesthetics.

\section{ACKNOWLEDGEMENTS}

We thank Jane Hayes, Information Manager, for designing the search strategy and Clare Jess and Gail Quinn, Managing Editors, for their contributions to the editorial process. 


\section{R E F E R E N C E S}

\section{References to studies included in this review}

\section{Al Kurdi 1985 \{published data only\}}

AI-Kurdi M, Hare M J, Lowles I, Douglas CP. The effect of a prostaglandin-synthetase inhibitor, naproxen sodium, and a placebo on the pain response to carbon dioxide laser treatment of the uterine cervix. Journal of Obstetrics and Gynaecology 1985;5:260-2.

\section{Connell 2000 \{published data only\}}

Connell RJ, Creighton SM, Cutner A. The effect of local anaesthetic spray on the pain associated with local anaesthetic injection, prior to biopsy or loop diathermy to the cervix in the outpatient colposcopy clinic. BJOG: An International Journal of Obstetrics \& Gynaecology 2000;107 (5):686-8

\section{Crompton 1992 \{published data only\}}

Crompton AC, Johnson N, Dudek U, Batra N, Tucker A. Is transcutaneous electrical nerve stimulation of any value during cervical laser treatment?. British Journal of Obstetrics \& Gynaecology 1992;99(6):492-4.

\section{Cruickshank 2005 \{published data only\}}

Anthony GB, Ross J, Tunstall M, Alexander D, Graham W, Fitzmaurice A, et al.A double blinded randomised controlled trial comparing standard analgesia versus standard analgesia and isodesox for the out-patient treatment of cervical intraepithelial neoplasia. Journal of Obstetrics and Gynaecology 2002;22(1): 108

* Cruickshank ME, Anthony GB, Fitzmaurice A, McConnell D, Graham W, Alexander DA, et al.A randomised controlled trial to evaluate the effect of selfadministered analgesia on women's experience of outpatient treatment at colposcopy. BJOG: An International Journal of Obstetrics \& Gynaecology 2005;112(12):1652-8.

Diakomanolis 1997 \{published data only\}

Diakomanolis E, Stefanidis KS, Rodolakis A, Sakellaropoulos G. Local vasoconstrictive effect of ornipressin (POR8) in laser conization of the cervix: a randomized study. Journal of Gynecologic Surgery 1997;13 (4):187-90

Duncan 2005 \{published data only\}

Duncan ID, McKinley CA, Pinion SB, Wilson SM. A double-blind, randomized, placebo-controlled trial of prilocaine and felypressin (Citanest and Octapressin) for the relief of pain associated with cervical biopsy and treatment with the Semm coagulator. Journal of Lower Genital Tract Disease 2005;9(3):171-5.

Frega 1994 \{published data only\}

Frega A, Stentella P, Di Renzi F, Gallo G, Palazzetti PL, Del Vescovo M, et al.Pain evaluation during carbon dioxide laser vaporization for cervical intraepithelial neoplasia: a randomized trial. Clinical \& Experimental Obstetrics \& Gynecology 1994;21(3):188-91.
Howells 2000 \{published data only\}

Howells RE, Tucker H, Millinship J, Shroff JF, Dhar KK, Jones PW, et al.A comparison of the side effects of prilocaine with felypressin and lignocaine with adrenaline in large loop excision of the transformation zone of the cervix: results of a randomised trial. BJOG: An International Journal of Obstetrics \& Gynaecology 2000;107(1):28-32.

Johnson 1989 \{published data only\} Johnson N, Crompton AC, Ramsden SV. The efficacy of paracervical injections of lignocaine before laser ablation of the cervical transformation zone. A randomized placebocontrolled double-blind clinical trial. British Journal of Obstetrics \& Gynaecology 1989;96(12):1410-2.

Johnson 1996 \{published data only\} Johnson N, Crompton AC, Doodek U. Comparing paracervical with direct infiltration of lignocaine for cervical laser surgery. Journal of Gynecologic Surgery 1996; Vol. 12 , issue 3:197-9.

Lee 1986 \{published data only\}

Lee ET, Ozumba EN, Bevan JR. A randomized trial of Citanest with Octapressin for relief of pain associated with laser vaporization of the cervix. British Journal of Obstetrics \& Gynaecology 1986;93(9):967-9.

Lipscomb 1995 \{published data only\}

Lipscomb GH, McCord ML, Bain KW, Ling FW. The effect of topical $20 \%$ benzocaine on pain during loop electrosurgical excision of the cervix. American Journal of Obstetrics \& Gynecology 1995;173(3 Pt 1):772-4.

Mikhail 1988 \{published data only\} Mikhail MG, Bevan JR. A randomized trial of the use of cocaine spray to provide pain relief during laser vaporization of the cervix. British Journal of Obstetrics \& Gynaecology 1988;95(5):469-72.

Rogstad 1992 \{published data only\} Rogstad KE, White DJ, Ahmed-Jushuf IH. Efficacy of lignocaine analgesia during treatment to the cervix. Lancet 1992;340(8825):942.

Sammarco 1993 \{published data only\} Sammarco MJ, Hartenbach EM, Hunter VJ. Local anesthesia for cryosurgery on the cervix. Journal of Reproductive Medicine 1993;38(3):170-2.

Sarkar 1993 \{published data only\} Sarkar PK, Williams JH, Davies Humphreys J. A doubleblind placebo-controlled trial of EMLA cream for the relief of pain associated with laser vapourisation for cervical pre-malignant conditions. Journal of Obstetrics and Gynaecology 1993; Vol. 13, issue 5:370-3.

Winters 2009 \{published data only\} Winters U, Keating PJ. A randomised controlled trial comparing two different local anaesthetic injection techniques prior to LLETZ. Journal of Obstetrics \& Gynaecology 2009;29(6):539-41. 


\section{References to studies excluded from this review}

\section{Sarkar 1990 \{published data only\}}

Sarkar PK. Topical anaesthesia with lignocaine-prilocaine cream (EMLA) for carbon dioxide treatment to the cervix a pilot study. British Journal of Clinical Practice 1990;44(9): 352-3.

Sharp 2009 \{published data only\}

Sharp L, Day N, Marteau T, Parmar M, Patnick J, Woodman C. Biopsy and selective recall compared with immediate large loop excision in management of women with low grade abnormal cervical cytology referred for colposcopy: multicentre randomised controlled trial. $B M J$ 2009;339(7716):330.

\section{Additional references}

\section{Deeks 2001}

Deeks JJ, Altman DG, Bradburn MJ. Statistical methods for examining heterogeneity and combining results from several studies in meta-analysis. In: Egger M, Davey Smith G, Altman DG editor(s). Systematic Reviews in Health Care: Meta-Analysis in Context. 2nd Edition. London: BMJ Publication Group, 2001.

DerSimonian 1986

DerSimonian R, Laird N. Meta-analysis in clinical trials. Controlled Clinical Trials 1986;7(3):177-88.

\section{EUROCARE 2003}

Sant M, Aareleid T, Berrino F, Bielska Lasota M, Carli PM, Faivre J, et al and the EUROCARE Working Group. EUROCARE-3: survival of cancer patients diagnosed 1990-94 - results and commentary. Annals of Oncology 2003;14 (Supplement 5):v61-v118.

\section{GLOBOCAN 2008}

Ferlay J, Shin HR, Bray F, Forman D, Mathers C, Parkin DM, International Agency for Research on Cancer. GLOBOCAN 2008, Cancer Incidence and Mortality Worldwide, 2010. IARC CancerBase No. 10, globocan.iarc.fr (accessed 29 August 2012).

Higgins 2003

Higgins JPT, Thompson SG, Deeks JJ, Altman DG. Measuring inconsistency in meta-analyses. BMJ 2003;327: 557-60.

Higgins 2011

Higgins JPT, Green S (editors). Cochrane Handbook for Systematic Reviews of Interventions Version 5.1.0 [updated March 2011]. The Cochrane Collaboration, 2011. Available from www.cochrane-handbook.org.

\section{Huskisson 1983}

Huskisson EC. Pain Measurement and Assessment. New York: Raven Press, 1983.

\section{Johnson 1994}

Johnston N, Crompton AC. Who finds cervical laser therapy painful?. Gynecologic Oncology 1994;52:44-9.

Jordan 1976 Jordan JA, Singer A. The Cervix. London: Saunders, 1976.

\section{Lowles 1983}

Lowles IE, Al-Kurdi M, Hare MJ. Women's recollection of pain during and after carbon-dioxide laser treatment to the uterine cervix. British Journal of Obstetrics and Gynaecology 1983;90:1157-9.

\section{Martin-Hirsch 2010}

Martin-Hirsch PL, Paraskevaidis E, Kitchener HC. Surgery for cervical intraepithelial neoplasia. Cochrane Database of Systematic Reviews 2010, Issue 6. [DOI: 10.1002/ 14651858.CD001318.pub2; : ]

\section{Melzack 1975}

Melzack R. The McGill Pain Questionnaire: major properties and scoring methods. Pain 1975;1:277-99.

Moore 2006

Moore KL, Dalley AF. Clinical Orientated Anatomy. 5th Edition. London: Lipincott Williams \& Wilkins, 2006.

\section{NHSCSP 2004}

Luesley D. Standards and Quality in Colposcopy. Programme (1996). NHSCSP publication no. 2. Sheffield, NHS Cervical Screening Programme, 2004.

\section{NHSCSP 2010}

Luesley D. Colposcopy and Programme Management: Guidelines for the NHS Cervical Screening Programme; 2nd edition. NHSCSP Publication no. 20, 2010.

\section{Peto 2004}

Peto J, Gilham C, Fletcher O, Matthews FE. The cervica cancer epidemic that screening has prevented in the UK. Lancet 2004;364(9430):249-56.

\section{Spielberger 1970} Spielberger CD, Gorsuch RL, Lushene RE. Manual for the State-Trait Anxiety Inventory. Palo Alto: Consulting Psychologists Press, 1970.

Zigmond 1983

Zigmond AS, Snaith RP. The Hospital Anxiety and Depression scale. Acta Psychiatrica Scandinavica 1983;67: 361-70.

* Indicates the major publication for the study 


\section{CHARACTERISTICS OF STUDIES}

\section{Characteristics of included studies [ordered by study ID]}

\section{Al Kurdi 1985}

Methods Prospective randomised double-blind trial Single centre

Participants

97 women satisfied the inclusion criteria and were entered into the study. 50 were allotted naproxen sodium treatment and 47 were given a placebo. Women were generally healthy and undergoing $\mathrm{CO}_{2}$ laser treatment for $\mathrm{CIN}$ for the first time. Pregnancy, lactation, a history of bronchial asthma or allergic diathesis, and concomitant use of highly protein bound drugs excluded women from entry to the trial. All women were assessed following laser treatment but 2 women from the naproxen sodium group failed to return their $24-$ hour questionnaire

Age 18 to 50 years

3 women from each group failed to complete their laser treatment because of pain and were subsequently given local or general anaesthetics. Their response to the laser treatment was recorded and included in the analysis

Interventions

2 naproxen sodium $550 \mathrm{mg}$ or 2 placebo tablets were given not less than 30 minutes before the $\mathrm{CO}_{2}$ laser treatment of the cervix was performed. Almost always the procedure started within 60 minutes of taking the tablets. Laser treatment was performed as previously described (Lowles 1983) and the duration of laser treatment and laser working time were recorded

Outcomes

VAS: a 10-cm VAS, which ranged from no pain to the worst pain ever experienced by the patient

Pain intensity was measured using both a VAS and VRS (none, very slight, mild, moderate, severe)

Speed of procedure reported as total treatment time

Various other outcomes not specified in our protocol

Notes

Analgesic use following treatment (in the naproxen sodium group only 2 out of 48 women used analgesics compared to 17 out of 47 women in the placebo group)

Self-reported side effects were very minor (aches and pains at 24 hours) and not included in analysis

\section{Risk of bias}

\begin{tabular}{lll}
\hline Bias & Authors' judgement & Support for judgement \\
\hline Allocation: sequence generation & Unclear risk & Not reported \\
\hline Allocation: sequence concealment & Unclear risk & Not reported \\
\hline $\begin{array}{l}\text { Performance and detection: blinding } \\
\text { All outcomes }\end{array}$ & Unclear risk & Not reported
\end{tabular}

Pain relief for women with cervical intraepithelial neoplasia undergoing colposcopy treatment (Review)

Copyright () 2012 The Cochrane Collaboration. Published by John Wiley \& Sons, Ltd. 


\section{Al Kurdi 1985 (Continued)}

\begin{tabular}{|c|c|c|}
\hline $\begin{array}{l}\text { Detection: blind outcome assessment } \\
\text { All outcomes }\end{array}$ & Unclear risk & Not reported \\
\hline $\begin{array}{l}\text { Attrition: incomplete outcome data } \\
\text { All outcomes }\end{array}$ & Low risk & $\begin{array}{l}\% \text { analysed: } 97 / 97(100 \%) \text { women were } \\
\text { analysed for pain. } 2 \text { women in treatment } \\
\text { arm did not reply to } 24 \text {-hour questionnaire, } \\
\text { but we assessed women immediately after } \\
\text { treatment to eliminate recall bias }\end{array}$ \\
\hline Reporting: unreported outcomes & Low risk & $\begin{array}{l}\text { Pertinent outcomes were reported in the } \\
\text { trial }\end{array}$ \\
\hline Other: anything else & Low risk & No additional form of bias was likely \\
\hline
\end{tabular}

\section{Connell 2000}

Methods

Prospective, randomised, double-blind, placebo-controlled study

Setting: colposcopy clinics at teaching hospital

Participants

Women aged 20 to 64 years who were undergoing biopsy or loop excision under local anaesthetic for cytological abnormalities were recruited to the study. Of the 51 women entered into the study, 19 had a biopsy performed and were excluded from analysis. 32 had a LLETZ and were included for analysis. 16 were randomised to receive solution A (lignocaine spray) and 16 had solution B (saline). 2 women in group failed to complete the second VAS so effectively 30 women were included in the final analysis - 15 in each of 2 groups

Interventions

Women were randomised to receive either the lignocaine hydrochloride $10 \%$ spray or saline. Multiple atomiser bottles were made up with solution and were labelled 'A' or 'B'. The spray was primed and the operator depressed the spray 4 times applying approximately $0.5 \mathrm{~mL}$ of solution to the cervix. At least 1 minute later $1.1 \mathrm{~mL}$ of local anaesthetic (prilocaine hydrochloride $30 \mathrm{mg} / \mathrm{mL}$ with felypressin $0.54 \mu \mathrm{g} / \mathrm{mL}$ ) was injected with a dental syringe and needle. In the LLETZ group injection was into 4 quadrants, the total volume being $4.4 \mathrm{~mL}$

Outcomes

Pain was measured using 100-mm VAS score. The woman was asked to mark the line with a cross as soon as the injections had been performed. Pain was also assessed with a 4-point categorical scale: 1 = not painful; 2 = slightly painful; 3 = moderately painful; 4 = severely painful

Notes

Pain was only reported on VAS. The outcome reported on categorical scale was not included in the analysis

Risk of bias

Bias

Authors' judgement

Support for judgement

Pain relief for women with cervical intraepithelial neoplasia undergoing colposcopy treatment (Review)

Copyright @ 2012 The Cochrane Collaboration. Published by John Wiley \& Sons, Ltd. 


\section{Connell 2000 (Continued)}

\begin{tabular}{|c|c|c|}
\hline Allocation: sequence generation & Low risk & $\begin{array}{l}\text { "Randomisation was by stratified com- } \\
\text { puter-generated numbers" }\end{array}$ \\
\hline Allocation: sequence concealment & Low risk & $\begin{array}{l}\text { To ensure blinding, the bottles were made } \\
\text { up in the pharmacy department who also } \\
\text { sealed the code in an envelope }\end{array}$ \\
\hline $\begin{array}{l}\text { Performance and detection: blinding } \\
\text { All outcomes }\end{array}$ & Low risk & $\begin{array}{l}\text { The attending doctor, the nursing staff, } \\
\text { the woman and the investigator were all } \\
\text { blinded to the identification of the solution } \\
\text { used }\end{array}$ \\
\hline $\begin{array}{l}\text { Detection: blind outcome assessment } \\
\text { All outcomes }\end{array}$ & Unclear risk & Not reported \\
\hline $\begin{array}{l}\text { Attrition: incomplete outcome data } \\
\text { All outcomes }\end{array}$ & Low risk & $\begin{array}{l}\% \text { analysed: } 94 \%(30 / 32) \text { analysed for all } \\
\text { outcomes }\end{array}$ \\
\hline Reporting: unreported outcomes & High risk & $\begin{array}{l}\text { Blood loss and duration of procedure was } \\
\text { not reported. The outcome for categorical } \\
\text { scale of pain relief was not available to carry } \\
\text { out comparison }\end{array}$ \\
\hline Other: anything else & Low risk & No additional risk of bias was likely \\
\hline
\end{tabular}

\section{Crompton 1992}

Methods

Participants
Prospective randomised 3-arm controlled clinical trial

Setting: colposcopy unit adapted to run randomised trials

100 women with a colposcopic diagnosis of CIN were recruited. They had a gynaecological interview, colposcopy and a colposcopically directed biopsy. Linear analogue anxiety and HAD anxiety/depression personality trait scores (Zigmond 1983), age and number of vaginal deliveries were recorded to assess group comparability. Women who had a past history of treatment for CIN, other cervical surgery or pelvic inflammatory disease, postmenopausal women and women with cardiac pacemakers were excluded. 2 other women refused to enter the trial

Mean (SD) age at trial entry: TENS only: $N=34,31.8$ years $(S D=9)$; local anaesthetic: $\mathrm{N}=35,32.6$ years $(\mathrm{SD}=9)$; TENS and local anaesthetic: $\mathrm{N}=29,30.1$ years $(\mathrm{SD}=8)$ $\%$ of women who were nullipara: TENS only: $48 \%$; local anaesthetic: $44 \%$; TENS plus local anaesthetic: $35 \%$

Median anxiety HAD score (interquartile range): TENS only: 6 (5 to 11$)$, local anaesthetic: 7 (4 to 9), TENS plus local anaesthetic: 6.5 (4 to 8)

Median depression HAD score (interquartile range): TENS only: 3 (1 to 4 ), local anaesthetic: 2 (1 to 4 ), TENS plus local anaesthetic: 3 (1 to 3 ) 


\begin{tabular}{|c|c|}
\hline Interventions & $\begin{array}{l}\text { Subjects were allocated to } 1 \text { of } 3 \text { groups: (1) TENS ( } \mathrm{N}=34) \text {, (2) TENS plus direct } \\
\text { infiltration of } 2 \mathrm{~mL} \text { lignocaine } 2 \% \text { plus octapressin } 1: 10,000(0.03 \mathrm{IU} / \mathrm{mL})(\mathrm{N}=29) \\
\text { and (3) direct infiltration of } 2 \mathrm{~mL} 2 \% \text { lignocaine plus octapressin }(\mathrm{N}=35) \text {. A total } \\
\text { of } 2 \mathrm{~mL} \text { of lignocaine } 2 \%+\text { octapressin was injected from a dental syringe via a 30- } \\
\text { gauge needle into } 4 \text { points on the TZ to a depth of } 3 \text { to } 5 \mathrm{~mm} \text {. Microtens TENS } \\
\text { pads (Neen Pain Management Systems, Norfolk, UK) were applied } 20 \text { minutes before } \\
\text { treatment. } 4 \text { conductive silicone polymer electrodes were applied using conducting gel } \\
\text { and tape fixative; } 2 \text { anterior to the abdominal wall just above the symphysis pubis and } 1 \\
\text { on each side of the sacrum. The electrodes were connected to an } 80-\mathrm{Hz} \text { nerve stimulator } \\
\text { (pulse width } 210 \mu \text { s) by a cable. The single channel amplitude control was activated by } \\
\text { the patients under instruction. Initially they were encouraged to experience a tingling } \\
\text { sensation and then they increased the amplitude until it became uncomfortable. They } \\
\text { were given approximately } 20 \text { minutes to experiment with the device until they were } \\
\text { called into the second room for laser treatment. All the treatments were carried out in } \\
\text { this second room by a second operator. The entire ectocervical TZ was either ablated to } \\
\text { a depth of approximately } 7 \mathrm{~mm} \text { or excised with the aid of skin hooks using a } 35-\mathrm{W} \mathrm{CO}_{2} \\
\text { laser (spot size } 1.5 \mathrm{~mm} \text { ) }\end{array}$ \\
\hline
\end{tabular}

Outcomes

At the end of the procedure the surgeon gave a further explanation of the treatment and scored the pain experienced by the patient using 120 -mm visual linear analogue scores. The scores were converted into percentages

At the end of the procedure the women offered TENS were given a simple questionnaire. They were asked to answer 'Yes' or 'No' to indicate whether or not they found the TENS each of the following: (1) comfortable, (2) unpleasant, (3) helpful, (4) frightening, (5) soothing or (6) pain relieving

Median pain score was on 120-mm VAS; however, authors converted it to percentage for reporting

\section{Risk of bias}

\begin{tabular}{|c|c|c|}
\hline Bias & Authors' judgement & Support for judgement \\
\hline Allocation: sequence generation & Unclear risk & Not reported \\
\hline Allocation: sequence concealment & High risk & $\begin{array}{l}\text { "The block randomisation code was held } \\
\text { by one investigator who then allocated } \\
\text { treatment" }\end{array}$ \\
\hline
\end{tabular}

Performance and detection: blinding High risk All outcomes
"It was impossible to conceal the use of TENS from the surgeon and patients but we had intended to 'blind' the attendants to the use of local anaesthesia. Injections of lignocaine were given in a separate room before the laser surgery was carried out by a different attendant but the surgeon was able to identify points where local anaesthetic had been given" 


\section{Crompton 1992 (Continued)}

\begin{tabular}{l|l|l}
\hline $\begin{array}{l}\text { Detection: blind outcome assessment } \\
\text { All outcomes }\end{array}$ & Unclear risk & Not reported \\
\hline $\begin{array}{l}\text { Attrition: incomplete outcome data } \\
\text { All outcomes }\end{array}$ & Low risk & $\begin{array}{l}\text { \% analysed: 98\% (98/100) analysed for all } \\
\text { outcomes }\end{array}$ \\
\hline Reporting: unreported outcomes & Unclear risk & $\begin{array}{l}\text { Median pain scores reported rather than } \\
\text { mean and adverse events were not reported }\end{array}$ \\
\hline Other: anything else & Unclear risk & $\begin{array}{l}\text { Insufficient information to permit judge- } \\
\text { ment }\end{array}$ \\
\hline
\end{tabular}

\section{Cruickshank 2005}

$\begin{array}{ll}\text { Methods } & \text { Prospective double-blind RCT } \\ \text { A colposcopy clinic serving a regional population in single-centre setting }\end{array}$

Participants

396 women scheduled for treatment of CIN by LLETZ. All women attending for investigation of an abnormal smear were screened and women suitable for treatment at their first visit ('see and treat'). Most women were seen for initial colposcopic assessment with directed punch biopsies only and treatment at a later appointment if necessary. Women were excluded if treatment was deferred because of pregnancy, if they were currently taking a monoamine oxidase inhibitor or if they had to drive home from the clinic themselves

Mean age at trial entry was 32.7 years (SD 9.8) and 31.5 (SD 9.1) in the isoflurane plus desflurane and placebo arms, respectively

Deprivation score details were as follows:

Class 1 (least deprived): 82 (82/395, 20.7\%); Class 2: 72 (18.2\%); Class 3: 53 (13.4\%)

; Class 4: 37 (9.4\%); Class 5: 36 (9.1\%); Class 6: 16 (4.0\%); Class 7: 46 (11.6\%); not classified: 53 (13.4\%)

Parity details were as follows: no children: 158 (40.3\%), 1 to 5 children: 234 (59.7\%)

Interventions

The intervention was a mixture of isoflurane and desflurane gases $(\mathrm{N}=195)$ versus placebo (air) $(\mathrm{N}=194)$. Both gases were self-administered by the women using a demand valve regulator (Ohmeda) as is used for Entonox. The slight odour of the trial gas was masked by a small amount of peppermint oil smeared inside the facemask for trial and control gas administration. The women were instructed to use the gas before the procedure began and to continue to use the gas according to their own requirements. Exhaled gas was scavenged using standard equipment (Ohmeda). Infiltration of the cervix with prilocaine hydrochloride $(30 \mathrm{mg} / \mathrm{mL})$ and octapressin $(0.54 \mathrm{mg} / \mathrm{mL})$ was started approximately 2 minutes after the start of inhalation. 2 to 3 ampoules were used at the clinical discretion of the colposcopist depending on the size of the cervical lesion. A number of different colposcopists performed treatment and were evenly distributed between the 2 arms

Outcomes

Pain measured using VAS ( 0 to 100 where 100 was worst pain imaginable)

Heavy vaginal bleeding

Anxiety using HAD

Pain relief for women with cervical intraepithelial neoplasia undergoing colposcopy treatment (Review) 
Various other outcomes not specified in our protocol

\begin{tabular}{|c|c|c|}
\hline Notes & \multicolumn{2}{|c|}{$\begin{array}{l}\text { Women were followed up immediately after colposcopy and at } 6 \text { months after. We did } \\
\text { not report } 6 \text { month data as recall bias was likely to be a problem } \\
\text { "Took pain killer for stomach pain" - this outcome did not mention the time limit from } \\
\text { procedure and so it was excluded from analysis (intervention group: } 66 / 175 \text {; comparison } \\
\text { group: } 66 / 173 \text { ) } \\
9 / 175 \text { and } 7 / 173 \text { women had difficulty returning to normal activity after colposcopy in } \\
\text { intervention and placebo groups, respectively } \\
14 / 175 \text { and } 15 / 173 \text { women contacted on-call service with problem related to treatment } \\
\text { in intervention and placebo groups, respectively } \\
\text { These } 2 \text { outcomes were not included in forest plots since descriptions were vague and } \\
\text { full details were not provided }\end{array}$} \\
\hline \multicolumn{3}{|l|}{ Risk of bias } \\
\hline Bias & Authors' judgement & Support for judgement \\
\hline Allocation: sequence generation & Low risk & $\begin{array}{l}\text { "The random allocation of women to } \\
\text { the cylinder code used computer-generated } \\
\text { random numbers" }\end{array}$ \\
\hline Allocation: sequence concealment & Low risk & $\begin{array}{l}\text { "The random allocation of women ... used } \\
\text {... a series of opaque sequentially numbered } \\
\text { envelopes" }\end{array}$ \\
\hline $\begin{array}{l}\text { Performance and detection: blinding } \\
\text { All outcomes }\end{array}$ & Low risk & $\begin{array}{l}\text { "The trial and clinic staff and trial partic- } \\
\text { ipants were blinded to the contents of the } \\
\text { cylinders, and peppermint oil was applied } \\
\text { to the facemask prior to use" }\end{array}$ \\
\hline $\begin{array}{l}\text { Detection: blind outcome assessment } \\
\text { All outcomes }\end{array}$ & Low risk & $\begin{array}{l}\text { "The subject matter was tabulated by an as- } \\
\text { sessor blinded to the randomisation of each } \\
\text { individual" }\end{array}$ \\
\hline $\begin{array}{l}\text { Attrition: incomplete outcome data } \\
\text { All outcomes }\end{array}$ & Low risk & $\begin{array}{l}\text { \% analysed: } 348 / 395(88 \%) \text { for heavy vagi- } \\
\text { nal bleeding outcome. Other outcomes as- } \\
\text { sessed more than } 88 \% \text { of women in the trial }\end{array}$ \\
\hline Reporting: unreported outcomes & High risk & Adverse events of gas were not reported \\
\hline Other: anything else & Low risk & No additional form of bias was likely \\
\hline
\end{tabular}




\begin{tabular}{ll} 
Methods & $\begin{array}{l}\text { Randomised double-blind study } \\
\text { Single centre }\end{array}$ \\
\hline Participants & $\begin{array}{l}100 \text { women were randomly allocated to } 1 \text { of } 2 \text { groups. All underwent laser excision of } \\
\text { TZ for CIN. All women included in the study had abnormal Pap smears. Abnormal } \\
\text { colposcopic findings, histologically confirmed CIN and were premenopausal. All women } \\
\text { with history of coronary disease, epilepsy and chronic hypertension were excluded from } \\
\text { the study } \\
\text { Median age of patient in Group A (vasoconstrictor + lignocaine) } 28 \text { years (range } 17 \text { to } \\
50) \\
\text { Median age of patient in Group B (lignocaine only) } 28.5 \text { years (range } 19 \text { to } 51)\end{array}$ \\
\hline $\begin{array}{l}\text { Group A vasoconstrictor }+ \text { lignocaine) consisted of } 50 \text { women who underwent laser } \\
\text { excision using } 30 \text { mL of a } 1: 30 \text { POR8 (vasoconstrictor) + lignocaine } 1 \% \text { solution The } \\
\text { ectocervix was infiltrated with solution just before the start of procedure using a } 30- \\
\text { gauge dental needle on a dental syringe to a depth of } 3 \text { to } 4 \text { cm } \\
\text { Group B (lignocaine only) consisted of } 50 \text { women who underwent laser excision received } \\
30 \text { mL of lignocaine } 1 \% \text { solution without POR8 - vasoconstrictor }\end{array}$
\end{tabular}

The intraoperative blood loss was measured with a glass blood measure (maximum volume $60 \mathrm{~mL}$ ) (used in paediatric surgery) set in the suction apparatus

Postoperative haemorrhage was measured with weighing the blood that soaked the pads Early haemorrhage was defined as bleeding occurring within 4 days of operation that requires intervention to stop bleeding. Late haemorrhage was after 4 days

Pain relief was recorded as VRS (none, moderate and severe) postoperatively

The operative time of each procedure was recorded. After the procedure, all women were contacted by telephone 1 week later in 7 women in Group A (vasoconstrictor + lignocaine) while in 2 women in Group B (lignocaine only)

Note: the $30 \mathrm{~mL}$ of local anaesthetic with vasoconstrictor or local anaesthetic alone is considered a higher than average amount used to infiltrate cervix in pain relief for colposcopic management

\section{Risk of bias}

\begin{tabular}{l|ll}
\hline Bias & Authors' judgement & Support for judgement \\
\hline Allocation: sequence generation & Unclear risk & Not reported \\
\hline Allocation: sequence concealment & Low risk & $\begin{array}{l}\text { "The randomization was performed as the } \\
\text { central pharmacy of the hospital during the } \\
\text { preparation and distribution of both med- } \\
\text { ications used" }\end{array}$ \\
\hline $\begin{array}{l}\text { Performance and detection: blinding } \\
\text { All outcomes }\end{array}$ & Low risk & $\begin{array}{l}\text { "The surgeon was not aware of the medi- } \\
\text { cation that was used" }\end{array}$
\end{tabular}


Diakomanolis 1997 (Continued)

\begin{tabular}{lll}
\hline $\begin{array}{l}\text { Detection: blind outcome assessment } \\
\text { All outcomes }\end{array}$ & Unclear risk & Not reported \\
\hline $\begin{array}{l}\text { Attrition: incomplete outcome data } \\
\text { All outcomes }\end{array}$ & Low risk & $\begin{array}{l}\text { \% analysed: } 100 / 100(100 \%) \text { analysed for } \\
\text { all outcomes }\end{array}$ \\
\hline Reporting: unreported outcomes & High risk & Pain was not analysed using VAS \\
\hline Other: anything else & Unclear risk & An additional form of bias was unlikely \\
\hline
\end{tabular}

Duncan 2005

Methods

Participants
Double-blind randomised prospective placebo-controlled trial

Single centre

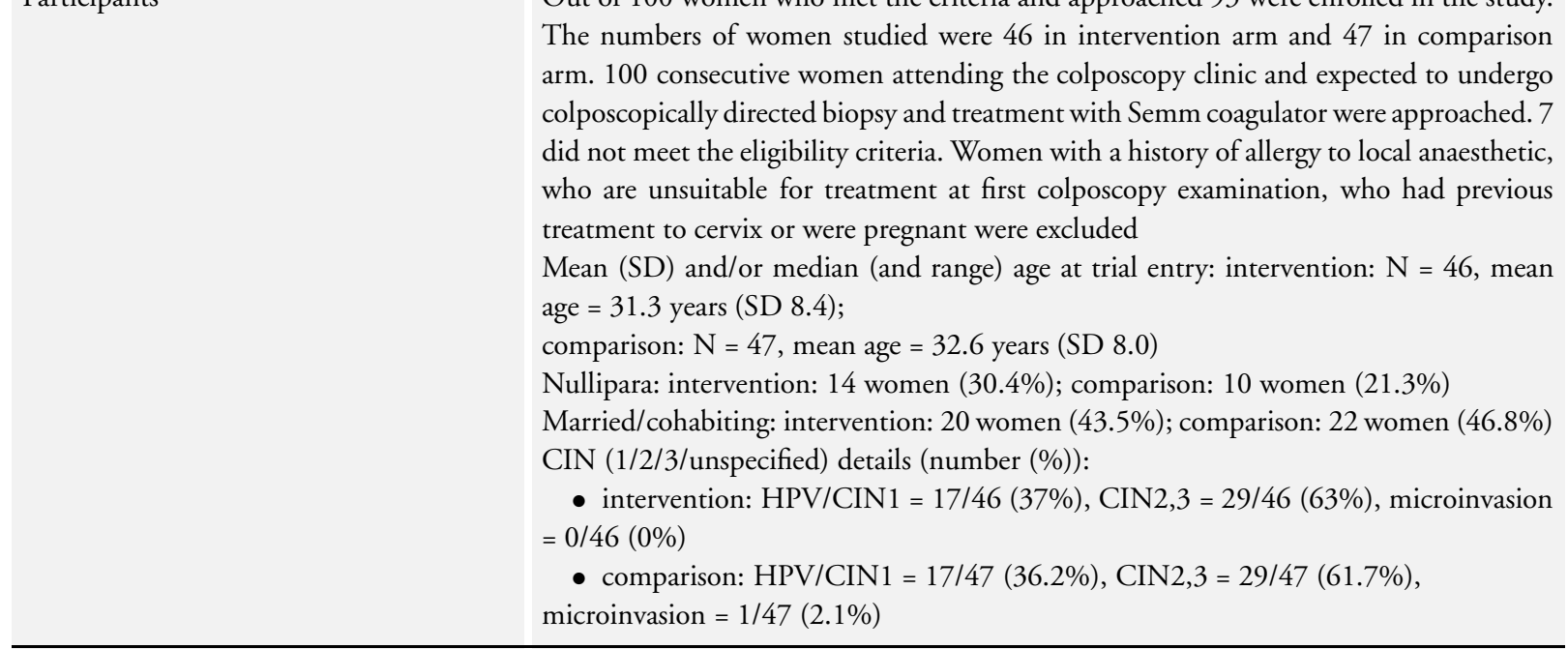

Interventions

Outcomes

Pain was recorded on 11-point analogue scale where 0 was no pain at all and 10 indicated the worst pain imaginable. Each patient was asked to complete 4 such scales: expected and actual sensation for biopsy and treatment. Pain scores of 1 to 3 were classified as mild, 4 to 7 as moderate and 8 to 10 as severe

Notes

Details of anticipated pain was excluded from the analysis

\section{Risk of bias}

Pain relief for women with cervical intraepithelial neoplasia undergoing colposcopy treatment (Review) 
Duncan 2005 (Continued)

\begin{tabular}{|c|c|c|}
\hline Bias & Authors' judgement & Support for judgement \\
\hline Allocation: sequence generation & Unclear risk & Not reported \\
\hline Allocation: sequence concealment & Low risk & $\begin{array}{l}\text { "Externally identical, numbered vials of ac- } \\
\text { tive medications or normal saline were pre- } \\
\text { pared by the in house pharmacy depart- } \\
\text { ment along with randomised opaque sealed } \\
\text { envelopes, each containing the number of } \\
\text { a vial. Pharmacy retained the key to the vial } \\
\text { contents until the end of the trial" }\end{array}$ \\
\hline $\begin{array}{l}\text { Performance and detection: blinding } \\
\text { All outcomes }\end{array}$ & Unclear risk & $\begin{array}{l}\text { Labelled as double blind placebo controlled } \\
\text { trial, but details are not documented in ma- } \\
\text { terials and methods section }\end{array}$ \\
\hline $\begin{array}{l}\text { Detection: blind outcome assessment } \\
\text { All outcomes }\end{array}$ & Unclear risk & See above \\
\hline $\begin{array}{l}\text { Attrition: incomplete outcome data } \\
\text { All outcomes }\end{array}$ & Low risk & $\begin{array}{l}\% \text { analysed: } 92 / 93(99 \%) \text { of the women } \\
\text { were analysed for pain related to treatment. } \\
\text { Data from } 1 \text { patient were missing in the } \\
\text { active drug group }\end{array}$ \\
\hline Reporting: unreported outcomes & High risk & Adverse event were not reported \\
\hline Other: anything else & Low risk & An additional form of bias was unlikely \\
\hline
\end{tabular}

\section{Frega 1994}

\begin{tabular}{l|l}
\hline Methods & Randomised study \\
\hline Participants & $\begin{array}{l}63 \text { women affected by CIN of various degrees were randomly divided into } 3 \text { groups in } \\
\text { order to evaluate the pain experienced during laser vaporisation of the lesion. All women } \\
\text { were premenopausal and ages ranged between } 19 \text { and } 39 \text { years. Each group consisted of } \\
21 \text { women }\end{array}$ \\
\hline Interventions & $\begin{array}{l}\text { The first group received naproxen sodium } 550 \text { mg } 30 \text { minutes before treatment; the } \\
\text { second group received placebo } 30 \text { minutes before treatment and the third no drug (21 } \\
\text { women in each group) }\end{array}$ \\
\hline Outcomes & \begin{tabular}{l} 
At the end of the procedure, the severity of pain was assessed using 0- to $100-m m ~ V A S$ \\
\hline Notes
\end{tabular} \\
$\begin{array}{l}\text { Mean and SD for each group was calculated from figure } 1 \text { on page } 189 \text { of the publication, } \\
\text { using GraphPad Prism software package, where the graphs were enlarged allowing an } \\
\text { accurate estimate of each individuals pain score } \\
\text { Since the trial included } 3 \text { arms, the shared intervention group was divided out approxi- } \\
\text { mately evenly among the comparisons. Hence for pain outcome on VAS, the total num- }\end{array}$ \\
\hline
\end{tabular}


ber of women in the drug group was divided up into 2 (the total number of 21 in the group was halved and rounded up to 11) and the means and SDs were left unchanged (see Higgins 2011, chapter 16.5.4)

\section{Risk of bias}

\begin{tabular}{l|l|l}
\hline Bias & Authors' judgement & Support for judgement \\
\hline Allocation: sequence generation & Unclear risk & Not reported \\
\hline Allocation: sequence concealment & Unclear risk & Not reported \\
\hline $\begin{array}{l}\text { Performance and detection: blinding } \\
\text { All outcomes }\end{array}$ & Unclear risk & Not reported \\
\hline $\begin{array}{l}\text { Detection: blind outcome assessment } \\
\text { All outcomes }\end{array}$ & Unclear risk & Not reported \\
\hline $\begin{array}{l}\text { Attrition: incomplete outcome data } \\
\text { All outcomes }\end{array}$ & Low risk & \% analysed: 63/63 (100\%) analysed for all outcomes \\
\hline Reporting: unreported outcomes & High risk & $\begin{array}{l}\text { Median rather than mean used for pain and adverse events were } \\
\text { not reported }\end{array}$ \\
\hline Other: anything else & Unclear risk & Insufficient information to permit judgement \\
\hline
\end{tabular}

Howells 2000

Methods

Participants
Prospective RCT

Setting: colposcopy clinic

200 consecutive women referred by general practitioners with abnormal cervical cytology $(\mathrm{N}=180)$ or clinically suspicious abnormality $(\mathrm{n}=20)$ were enrolled Inclusion criteria for the study were: women aged 20 and 60 years; who had received no previous treatment to the cervix who require treatment

Mean age (SD) (prilocaine plus felypressin vs. lignocaine plus adrenaline): 94 women; 36.6 years (10.3) vs. 106 women; 34.6 years (9.7)

Menopausal status (prilocaine plus felypressin vs. lignocaine plus adrenaline):

premenopausal: $81(86 \%)$ vs. $96(91 \%)$; postmenopausal: $12(13 \%)$ vs. $9(8 \%)$; missing data: $1(1 \%)$ vs. $1(1 \%)$

Contraception (prilocaine plus felypressin vs. lignocaine plus adrenaline): no: 37 (39\%) vs. 44 (42\%); yes: $61(65 \%)$ vs. 76 (72\%); missing data: 0 vs. $1(1 \%)$

Smear grade (prilocaine plus felypressin vs. lignocaine plus adrenaline):

- low grade/negative: 35 (37\%) vs. 49 (46\%)

- high grade: $53(57 \%)$ vs. $51(48 \%)$

- other grades: 5 (5\%) vs. 4 (4\%)

Nullipara (prilocaine plus felypressin vs. lignocaine plus adrenaline): 17 (18\%) vs. 24 $(23 \%)$ 
Howells 2000 (Continued)

Colposcopic findings (prilocaine plus felypressin vs. lignocaine plus adrenaline): normal: $13(14 \%)$ vs. 15 (14\%); low grade: 25 (27\%) vs. 29 (27\%); high grade: 49 (52\%) vs. $53(50 \%)$; uncertain: $5(5 \%)$ vs. 7 (7\%); ? invasion: 1 (1\%) vs. 1 (1\%); missing data: 1 (1\%) vs. $1(1 \%)$

Final histology (prilocaine plus felypressin vs. lignocaine plus adrenaline): normal: 4 (4\%) vs. 8 (8\%); low grade: $36(38 \%)$ vs. 31 (29\%); high grade: $51(55 \%)$ vs. $63(59 \%)$ ; others: $3(3 \%)$ vs. $2(2 \%)$; missing data: 0 vs. $2(2 \%)$

Final histology was negative for (prilocaine plus felypressin vs. lignocaine plus adrenaline) : 4/94 (4\%) vs. 8/106 (8\%); exclusion from analysis not possible so included in analysis Local anaesthetic volume $(\mathrm{mL})$ (prilocaine plus felypressin vs. lignocaine plus adrenaline) : $5.02 \mathrm{~mL}$ vs. $4.83 \mathrm{~mL}$

Loop passes (prilocaine plus felypressin vs. lignocaine plus adrenaline): 1 pass: $71(76 \%)$ vs. 80 (75\%); 2 passes: 19 (20\%) vs. 18 (17\%); 3 passes: 2 (\%) vs. 4 (4\%)

Loop size (prilocaine plus felypressin vs. lignocaine plus adrenaline): small: 10 (11\%) vs. 14 (13\%); medium: 80 (85\%) vs. 87 (82\%); large: $3(3 \%)$ vs. $1(1 \%)$; Missing data (prilocaine plus felypressin vs. lignocaine plus adrenaline): 1 (1\%) vs. 4 (4\%)

Interventions

Intervention group $(\mathrm{N}=94)$ received prilocaine $3 \%(30 \mathrm{mg} / \mathrm{mL})$ with felypressin 0.03 $\mathrm{IU} / \mathrm{mL}$. Comparison group $(\mathrm{N}=106)$ received lignocaine $2 \%$ with adrenaline $1: 80,000$ (xylocaine)

Outcomes

The duration of the treatment was calculated from the start of the loop excision to the end of ball diathermy used to achieve haemostasis

The colposcopist scored his or her perception of the discomfort experienced by the women in a scale of ordered categories $(0=$ 'none'; $4=$ 'severe' $)$ and also the degree of bleeding caused by the procedure ( $0=$ 'none'; 5 = 'heavy')

Following treatment, the women answered a questionnaire on their perception of pain during the administration of the local anaesthetic and during their treatment in a scale of ordered categories ( 0 = 'none'; 5 = 'unbearable')

Other side effects, such as feeling faint, nausea and shaking, were also scored in a similar fashion ( 0 = 'none'; 5 = 'a great deal'). The scores were then added to derive an overall score

Notes

Missing data (prilocaine plus felypressin vs. lignocaine plus adrenaline): 1 (1\%)vs. 2 $(2 \%)$

\section{Risk of bias}

\begin{tabular}{|c|c|c|}
\hline Bias & Authors' judgement & Support for judgement \\
\hline Allocation: sequence generation & Unclear risk & $\begin{array}{l}\text { "The women were randomised by an inde- } \\
\text { pendent observer using simple randomisa- } \\
\text { tion" }\end{array}$ \\
\hline Allocation: sequence concealment & Low risk & $\begin{array}{l}\text { "The women were randomised ... using } \\
\text { simple randomisation with opaque sealed } \\
\text { envelopes" }\end{array}$ \\
\hline
\end{tabular}

Pain relief for women with cervical intraepithelial neoplasia undergoing colposcopy treatment (Review) 
Howells 2000 (Continued)

\begin{tabular}{|c|c|c|}
\hline $\begin{array}{l}\text { Performance and detection: blinding } \\
\text { All outcomes }\end{array}$ & High risk & $\begin{array}{l}\text { "The colposcopists were aware of the iden- } \\
\text { tity of the local anaesthetic solutions" }\end{array}$ \\
\hline $\begin{array}{l}\text { Detection: blind outcome assessment } \\
\text { All outcomes }\end{array}$ & Unclear risk & Not reported \\
\hline $\begin{array}{l}\text { Attrition: incomplete outcome data } \\
\text { All outcomes }\end{array}$ & Low risk & $\%$ analysed: $200 / 200(100 \%)$ \\
\hline Reporting: unreported outcomes & High risk & $\begin{array}{l}\text { Important outcomes were reported by the } \\
\text { trial authors but these could have been } \\
\text { reported using more appropriate methods } \\
\text { (e.g. continuous data for pain and blood } \\
\text { loss, rather than using logistic regression for } \\
\text { non-parametric data) }\end{array}$ \\
\hline Other: anything else & Low risk & No additional form of bias was likely \\
\hline
\end{tabular}

\section{Johnson 1989}

\begin{tabular}{|c|c|}
\hline Methods & Prospective double-blind randomised placebo-controlled clinical trial \\
\hline Participants & $\begin{array}{l}70 \text { women with a new colposcopic and histological diagnosis of a cervical dysplastic } \\
\text { lesion suitable for laser ablation. The following prospective exclusion criteria were used: } \\
\text { previous cervical surgery, more than } 1 \text { colposcopic examination, menopausal or peri- } \\
\text { menopausal status, sensitivity to lignocaine, patient refusing paracervical injection or } \\
\text { refusing to be recruited into the trial, or vaginal involvement of the lesion }\end{array}$ \\
\hline Interventions & $\begin{array}{l}\text { Women were randomised to receive either lignocaine } 2 \% \text { or normal saline from a num- } \\
\text { bered vial. A bilateral paracervical block was delivered by injecting } 10 \mathrm{~mL} \text { into the parac- } \\
\text { ervical tissues }\end{array}$ \\
\hline Outcomes & $\begin{array}{l}\text { At the end of the procedure and after a further explanation, the women scored their } \\
\text { pain on a } 120 \text {-mm visual linear analogue scale. Pain was also objectively scored by the } \\
\text { attending nurse who assessed the woman's level of vocalisation }(2=\text { moan/cry; } 1 \text { = gasp; } \\
0=\text { no vocalisation), muscle tension of the upper limbs }(2=\text { the clenching the bed etc.; } 1 \\
\text { = making a fist; } 0=\text { relaxed), thigh movements }(2=\text { adduction; } 1=\text { twitchy; } 0=\text { relaxed) } \\
\text {. The laser operator independently scored movements of the thigh as well as perineal } \\
\text { movement ( } 2=\text { bottom movement up the bed; } 1=\text { speculum twitches; } 0=\text { no movement/ } \\
\text { relaxed). The size of the TZ and blood loss were recorded. Anxiety and depression HAD } \\
\text { scores and premenstrual syndrome scores were also recorded }\end{array}$ \\
\hline Notes & - \\
\hline
\end{tabular}

\section{Risk of bias}


Johnson 1989 (Continued)

\begin{tabular}{|c|c|c|}
\hline Allocation: sequence generation & Low risk & $\begin{array}{l}\text { "Consenting patients were then ran- } \\
\text { domised to receive either } 2 \% \text { lignocaine or } \\
\text { normal saline from a numbered vial. Each } \\
\text { vial could only be identified at the end of } \\
\text { the study by its number which was allo- } \\
\text { cated prospectively according to a block } \\
\text { randomised code" }\end{array}$ \\
\hline Allocation: sequence concealment & Low risk & $\begin{array}{l}\text { "Each vial could only be identified at the } \\
\text { end of the study by its number which was } \\
\text { allocated prospectively" }\end{array}$ \\
\hline $\begin{array}{l}\text { Performance and detection: blinding } \\
\text { All outcomes }\end{array}$ & Low risk & $\begin{array}{l}\text { Trial was labelled as a placebo-controlled } \\
\text { double-blind trial. "Laser ablation of the } \\
\text { entire transformation zone to a depth of } \\
\text { approximately } 7 \mathrm{~mm} \text { was performed with } \\
\text { a continuous fine beam (spot size } 1.5 \mathrm{~mm} \text { ) } \\
35 \text {-W CO, laser by a separate surgeon in a } \\
\text { second suite" }\end{array}$ \\
\hline $\begin{array}{l}\text { Detection: blind outcome assessment } \\
\text { All outcomes }\end{array}$ & Low risk & $\begin{array}{l}\text { "Pain was objectively scored by the attend- } \\
\text { ing nurse who assessed the woman's level of } \\
\text { vocalization ... muscle tension of the upper } \\
\text { limbs, thigh movements ... The laser op- } \\
\text { erator independently scored movements of } \\
\text { the thigh as well as perineal movement" }\end{array}$ \\
\hline $\begin{array}{l}\text { Attrition: incomplete outcome data } \\
\text { All outcomes }\end{array}$ & Low risk & $\%$ analysed: $70 / 70(100 \%)$ \\
\hline Reporting: unreported outcomes & High risk & $\begin{array}{l}\text { Adverse events of paracervical injections } \\
\text { were not reported and pain was inade- } \\
\text { quately reported }\end{array}$ \\
\hline Other: anything else & Low risk & No additional form of bias was likely \\
\hline
\end{tabular}

Johnson 1996

Methods

Double-blind randomised clinical trial

Colposcopic clinic specifically adapted to run clinical trials

Participants

44 (23 in intervention group and 21 in comparison group) women were recruited from a laser colposcopy clinic. They were referred following abnormal smear and underwent colposcopic examination and biopsy before being recruited. No participant refused entry in the trial but the trial was terminated prematurely when the laser surgeon realised that he could identify women given direct infiltration by looking for the injection mark. Following exclusion criteria were applied: past cervical surgery, past cervical atypia, vaginal involvement with lesion, the menopause, reluctance to take part in trial 
Johnson 1996 (Continued)

\begin{tabular}{l|l}
\hline Interventions & $\begin{array}{l}\text { This study compared site of injection of the pain relief. Intervention group received } \\
10 \mathrm{~mL} \text { of paracervical lignocaine } 2 \% \text { while the comparison group received } 2 \mathrm{~mL} \text { of } \\
\text { lignocaine } 2 \% \text { directly into the } \mathrm{TZ}\end{array}$ \\
\hline Outcomes & $\begin{array}{l}\text { Pain was scored on VAS at the end of the procedure by the patients. Pain was objectively } \\
\text { scored by the attending nurse and the laser operator independently }\end{array}$ \\
\hline Notes & - \\
\hline
\end{tabular}

Risk of bias

\begin{tabular}{|c|c|c|}
\hline Bias & Authors' judgement & Support for judgement \\
\hline Allocation: sequence generation & Low risk & $\begin{array}{l}\text { "Consenting women were block ran- } \\
\text { domised to receive either } 10 \mathrm{ml} \text { of paracer- } \\
\text { vical } 2 \% \text { lignocaine or } 2 \mathrm{ml} \text { of } 2 \% \text { ligno- } \\
\text { caine injected directly into the transforma- } \\
\text { tion zone" }\end{array}$ \\
\hline Allocation: sequence concealment & Low risk & $\begin{array}{l}\text { "Neither nurses, clerical officers responsible } \\
\text { for appointments, nor the laser surgeon had } \\
\text { access to this code. The worker responsible } \\
\text { for randomisation obtained consent, drew } \\
\text { the allocation code from a box" }\end{array}$ \\
\hline $\begin{array}{l}\text { Performance and detection: blinding } \\
\text { All outcomes }\end{array}$ & Low risk & $\begin{array}{l}\text { "The worker responsible for randomisation } \\
\text {... gave the local anaesthetic in a room sep- } \\
\text { arate from the laser suite" }\end{array}$ \\
\hline $\begin{array}{l}\text { Detection: blind outcome assessment } \\
\text { All outcomes }\end{array}$ & Low risk & $\begin{array}{l}\text { "Pain was objectively scored by the attend- } \\
\text { ing nurse who assessed the woman's level of } \\
\text { vocalization ... muscle tension of the upper } \\
\text { limbs and thigh movements. The laser op- } \\
\text { erator independently scored movements of } \\
\text { the thigh as well as perineal movement" }\end{array}$ \\
\hline $\begin{array}{l}\text { Attrition: incomplete outcome data } \\
\text { All outcomes }\end{array}$ & Low risk & $\%$ analysed: $44 / 44(100 \%)$ \\
\hline Reporting: unreported outcomes & High risk & $\begin{array}{l}\text { Adverse events of paracervical injections } \\
\text { were not reported and pain was inade- } \\
\text { quately reported }\end{array}$ \\
\hline Other: anything else & Unclear risk & $\begin{array}{l}\text { No woman refused entry to the trial, } \\
\text { but the study was terminated prematurely } \\
\text { when the laser surgeon realised that he } \\
\text { could identify women given direct infiltra- } \\
\text { tion by looking for the injection marks. Up } \\
\text { to this point, the study was a true double- }\end{array}$ \\
\hline
\end{tabular}

Pain relief for women with cervical intraepithelial neoplasia undergoing colposcopy treatment (Review) 
Johnson 1996 (Continued)

blind, randomised trial. This is not necessarily a source of bias but we were unsure whether any additional source of bias may have been present

Lee 1986

$\begin{array}{ll}\text { Methods } & \text { RCT }\end{array}$

Participants

50 women undergoing laser vaporisation of cervix for CIN were recruited to 1 of the 2 groups. All women were premenopausal and aged 19 to 39 years

Interventions

In the intervention group ( $\mathrm{N}=25)$, the ectocervix was infiltrated with $2 \mathrm{~mL}$ prilocaine $3 \%$ with felypressin $0.03 \mathrm{IU} / \mathrm{mL}$ immediately before the procedure, while in the comparison group $(\mathrm{N}=25)$ women received no analgesia or anaesthesia. Using a 30-gauge dental needle on a dental syringe, Infiltration around the periphery of the TZ was performed immediately before the procedure. Local anaesthetic was employed in the control group only when significant pain was experienced

Outcomes

The severity of the pain was assessed at the end of the procedure using VAS and VRS. The VAS consisted of a 100-mm line drawn on plain paper representing pain ranging from 'no pain at all' to 'pain as much as you can imagine'. Patients marked a point on the line at the end of the procedure which they felt corresponded to the pain they experienced. The VRS consisted of a choice of 4 descriptions, none, mild, moderate or severe. Blood loss during the procedure was recorded as none, slight, moderate and troublesome

Notes

Other outcome measures included pain while receiving the injection and the level of anxiety before the procedure was measured before the patient undressed using the Spielberger state anxiety inventory. Side effects such as sweating, nausea, dizziness and cramps were also reported. This was not included in the analysis

Mean and SD for each group was calculated from figure 1 on page 968 of the publication, using GraphPad Prism software package, where the graph was enlarged allowing an accurate estimate of each individuals pain score

\section{Risk of bias}

Bias

Authors' judgement Support for judgement

\begin{tabular}{l|l|l}
\hline Allocation: sequence generation & Unclear risk & Not reported \\
\hline Allocation: sequence concealment & Unclear risk & Not reported \\
\hline $\begin{array}{l}\text { Performance and detection: blinding } \\
\text { All outcomes }\end{array}$ & Unclear risk & Not reported \\
\hline $\begin{array}{l}\text { Detection: blind outcome assessment } \\
\text { All outcomes }\end{array}$ & Unclear risk & Not reported
\end{tabular}

Pain relief for women with cervical intraepithelial neoplasia undergoing colposcopy treatment (Review) 


\section{Lee 1986 (Continued)}

\begin{tabular}{l|l|l}
\hline $\begin{array}{l}\text { Attrition: incomplete outcome data } \\
\text { All outcomes }\end{array}$ & Low risk & $\%$ analysed: $50 / 50(100 \%)$ \\
\hline Reporting: unreported outcomes & Low risk & Pertinent outcomes were reported in the trial \\
\hline Other: anything else & Unclear risk & No additional form of bias was likely \\
\hline
\end{tabular}

Lipscomb 1995

Methods

Participants

Outcomes

Notes
Prospective double-blind RCT

50 women scheduled for the loop excision for treatment of cervical dysplasia were asked to participate in the study. All agreed to take part. Age and parity was comparable in both groups

Age: mean (SD) (intervention vs. comparison): 29.5 years (10.5) vs. 28.4 years (8.9)

Parity: mean (SD) (intervention vs. comparison): 2.1 (2.1) vs. 2.3 (1.6)

Loop passes: mean (SD) (intervention vs. comparison): $1.2(0.4)$ vs. $1.3(0.6)$

Positive margins: mean (SD) (intervention vs. comparison): $2 / 25$ vs. $3 / 25$

In the intervention arm, 25 women received cervical application of benzocaine $20 \%$ gel and in comparison arm women received a placebo gel before the procedure. In addition, all women also received preprocedural oral analgesia ketorolac tromethamine $10 \mathrm{mg}$ orally 30 minutes before procedure. After 1 minute of gel application, $1 \mathrm{~mL}$ of lignocaine $1 \%$ with adrenaline $1: 100,000$ was injected in $1 \mathrm{~mL}$ doses into the cervical stroma at the 12, 3, 6 and 9 o'clock positions (total $4 \mathrm{~mL}$ ) with 25 -gauge needle on a needle extender

Immediately after the procedure the women were asked to rate on a standard VAS the pain from injection as well as pain from loop excision procedure. The scale consisted of $10-\mathrm{cm}$ horizontal line with vertical cross bars at each endpoint. The endpoints were labelled 'no pain' and 'worst pain possible'

Other outcomes such as number of passes of the loop or details of margins of the loop were not included for the analysis

\section{Risk of bias}

\begin{tabular}{|c|c|c|}
\hline Bias & Authors' judgement & Support for judgement \\
\hline Allocation: sequence generation & Low risk & $\begin{array}{l}\text { "By use of computer-generated numbers, patients were } \\
\text { randomized to one of two groups" }\end{array}$ \\
\hline Allocation: sequence concealment & Unclear risk & Not reported \\
\hline $\begin{array}{l}\text { Performance and detection: blinding } \\
\text { All outcomes }\end{array}$ & Low risk & $\begin{array}{l}\text { "Both patient and physician were unaware which gel } \\
\text { the syringe contained" }\end{array}$ \\
\hline
\end{tabular}


Lipscomb 1995 (Continued)

\begin{tabular}{l|ll}
\hline $\begin{array}{l}\text { Detection: blind outcome assessment } \\
\text { All outcomes }\end{array}$ & Unclear risk & Not reported \\
\hline $\begin{array}{l}\text { Attrition: incomplete outcome data } \\
\text { All outcomes }\end{array}$ & Low risk & $\%$ analysed: $50 / 50(100 \%)$ \\
\hline Reporting: unreported outcomes & Unclear risk & Adverse events of gel were not reported \\
\hline Other: anything else & Low risk & No additional form of bias was likely \\
\hline
\end{tabular}

\section{Mikhail 1988}

\begin{tabular}{|c|c|}
\hline Methods & A randomised prospective double-blind placebo controlled trial \\
\hline Participants & $\begin{array}{l}50 \text { women undergoing laser vaporisation of the cervix for CIN were allocated to } 1 \text { of } \\
\text { the } 2 \text { groups. There were } 25 \text { women in each group. Characteristics of the } 2 \text { groups were } \\
\text { recorded } \\
\text { Age: mean (SD) (intervention vs. comparison): } 27.4 \text { years (3.9) vs. } 26.7 \text { years (4.57) } \\
\text { Parity: mean (SD): (intervention vs. comparison): } 0.9(1.24) \text { vs. } 1 \text { (1) }\end{array}$ \\
\hline Interventions & $\begin{array}{l}\text { In the intervention group }(\mathrm{N}=25) \text { the cervix was sprayed with } 3-4 \mathrm{~mL} \text { of a cocaine } \\
10 \% \text { solution preserved in nipasept (a mixture of the methyl, ethyl and propyl esters } \\
\text { of } p \text {-hydroxybenzoic acid). The comparison group }(\mathrm{N}=25 \text { ) was sprayed with a similar } \\
\text { quantity of the preservative alone. There was no indication on the spray to identify the } \\
\text { solution. When necessary, additional pain relief was given by the local infiltration of } \\
\text { prilocaine by hypodermic injection. } 1 \text { to } 2 \mathrm{~mL} \text { of the solution were sprayed on the cervix } \\
\text { and repeated as necessary through the procedure }\end{array}$ \\
\hline Outcomes & $\begin{array}{l}\text { The time taken to complete the treatment and assessment of the blood loss were noted. } \\
\text { The severity of the pain experienced was assessed at the end of the procedure using } \\
\text { standard 10-mm VAS (Huskisson 1983) and VRS. The VRS consisted of } 4 \text { categories - } \\
\text { none, mild, moderate or severe. Blood loss was assessed subjectively by the operator as } \\
\text { minimal, moderate and severe }\end{array}$ \\
\hline Notes & $\begin{array}{l}\text { Mean and SD for each group was calculated from figure } 1 \text { on page } 471 \text { of the publication, } \\
\text { using GraphPad Prism software package, where the graph was enlarged allowing an } \\
\text { accurate estimate of each individuals pain score }\end{array}$ \\
\hline
\end{tabular}

\section{Risk of bias}

\begin{tabular}{lll}
\hline Bias & Authors' judgement & Support for judgement \\
\hline Allocation: sequence generation & Low risk & $\begin{array}{l}\text { "The patients were allocated to their groups } \\
\text { by a computer-generated random list" }\end{array}$ \\
\hline Allocation: sequence concealment & Unclear risk & Not reported
\end{tabular}


Mikhail 1988 (Continued)

\begin{tabular}{l|l|l}
\hline $\begin{array}{l}\text { Performance and detection: blinding } \\
\text { All outcomes }\end{array}$ & Low risk & $\begin{array}{l}\text { "There was no indication on the spray to } \\
\text { identify the solution ... The randomized } \\
\text { and double-blind nature of the trial elimi- } \\
\text { nated observer bias" }\end{array}$ \\
\hline $\begin{array}{l}\text { Detection: blind outcome assessment } \\
\text { All outcomes }\end{array}$ & Unclear risk & Not reported \\
\hline $\begin{array}{l}\text { Attrition: incomplete outcome data } \\
\text { All outcomes }\end{array}$ & Low risk & \% analysed: $50 / 50(100 \%)$ \\
\hline $\begin{array}{l}\text { Reporting: unreported outcomes } \\
\text { Other: anything else }\end{array}$ & Low risk & $\begin{array}{l}\text { There reason to suspect outcomes were se- } \\
\text { lectively reported }\end{array}$ \\
\hline
\end{tabular}

\section{Rogstad 1992}

\begin{tabular}{ll}
\hline Methods & Randomised placebo-controlled double-blind trial \\
\hline Participants & 60 women who were scheduled to undergo cold coagulation for cervical abnormalities \\
\hline Interventions & $\begin{array}{l}21 \text { received lignocaine (intervention) and } 31 \text { received normal saline (comparison). Cervix } \\
\text { was infiltrated with } 2 \mathrm{~mL} \text { of lignocaine } 2 \% \text { or } 2 \mathrm{~mL} \text { of normal saline before cold coag- } \\
\text { ulation }\end{array}$ \\
\hline Outcomes & The degree of pain felt was measured by VRS and VAS \\
\hline Notes & $\begin{array}{l}\text { Other outcomes like pain of injection and } 3 \text { to } 6 \text { weeks' follow-up questionnaire of pain } \\
\text { and bleeding were excluded from the analysis } \\
\text { Mean and SD for each group was calculated from figure on page } 942 \text { of the publication, } \\
\text { using GraphPad Prism software package, where the graph was enlarged allowing an } \\
\text { accurate estimate of each individuals pain score }\end{array}$ \\
\hline
\end{tabular}

\section{Risk of bias}

\begin{tabular}{|c|c|c|}
\hline Bias & Authors' judgement & Support for judgement \\
\hline Allocation: sequence generation & Low risk & $\begin{array}{l}\text { "The trial was randomised, placebo con- } \\
\text { trolled and double-blind. Randomisation } \\
\text { was by computerised generation of random } \\
\text { numbers" }\end{array}$ \\
\hline Allocation: sequence concealment & Unclear risk & Not reported \\
\hline $\begin{array}{l}\text { Performance and detection: blinding } \\
\text { All outcomes }\end{array}$ & Unclear risk & $\begin{array}{l}\text { Labelled as double-blind placebo-con- } \\
\text { trolled trial, but details are not documented } \\
\text { in paper }\end{array}$ \\
\hline
\end{tabular}

Pain relief for women with cervical intraepithelial neoplasia undergoing colposcopy treatment (Review)

Copyright @ 2012 The Cochrane Collaboration. Published by John Wiley \& Sons, Ltd. 
Rogstad 1992 (Continued)

\begin{tabular}{l|l|l}
\hline $\begin{array}{l}\text { Detection: blind outcome assessment } \\
\text { All outcomes }\end{array}$ & Unclear risk & Not reported \\
\hline $\begin{array}{l}\text { Attrition: incomplete outcome data } \\
\text { All outcomes }\end{array}$ & Low risk & $\begin{array}{l}\text { \% analysed: } 60 / 60(100 \%) \text { for pain out- } \\
\text { come }\end{array}$ \\
\hline Reporting: unreported outcomes & High risk & Adverse events were not reported \\
\hline Other: anything else & Unclear risk & $\begin{array}{l}\text { Insufficient information to permit judge- } \\
\text { ment }\end{array}$ \\
\hline
\end{tabular}

Sammarco 1993

\begin{tabular}{ll}
\hline Methods & A prospective RCT \\
\hline Participants & $\begin{array}{l}\text { Each patient was evaluated by colposcopy with biopsy and had a histological diagnosis of } \\
\text { cervical dysplasia. They were scheduled to undergo cryosurgery. Cryosurgery was carried } \\
\text { out with liquid nitrogen using Cryo-2000 (Valleylab, Boulder, Colorado) by double } \\
\text { freeze technique with a 3-minute freeze and 5-minutes thaw cycle. Nulliparous women, } \\
\text { those under } 16 \text { years of age and those with allergies were excluded. Women with no } \\
\text { endocervical disease and lesions of less than } 3 \text { cm were eligible }\end{array}$ \\
\hline Interventions & $\begin{array}{l}\text { Both control and intervention group received a single dose of ketoprofen } 75 \text { mg (a } \\
\text { non-steroidal anti-inflammatory drug) within } 1 \text { hour of procedure, } 2 \text { women received } \\
\text { naproxen sodium } 550 \text { mg. The control group received no further analgesia. The in- } \\
\text { tervention women received an injection of } 2 \text { to } 3 \text { mL of lignocaine with a } 1: 100,000 \\
\text { dilution of adrenaline, which was administered submucosally at the } 2 \text { and } 10 \text { o'clock } \\
\text { positions with } 25 \text {-gauge needle } 1 \text { minute prior to the cryosurgery }\end{array}$ \\
\hline
\end{tabular}

Outcomes

A VAS with 0 representing no pain and 10 representing severe pain, was used to evaluate the amount of pain experienced by the patient

Notes

Mean VAS score recorded by nurses was not included in analysis owing to high risk of bias

\section{Risk of bias}

\begin{tabular}{l|l|l}
\hline Bias & Authors' judgement & Support for judgement \\
\hline Allocation: sequence generation & Unclear risk & Not reported \\
\hline $\begin{array}{l}\text { Allocation: sequence concealment } \\
\begin{array}{l}\text { Performance and detection: blinding } \\
\text { All outcomes }\end{array}\end{array}$ & Unclear risk & Not reported \\
\hline
\end{tabular}


Sammarco 1993 (Continued)

\begin{tabular}{l|l|l|}
\hline $\begin{array}{l}\text { Detection: blind outcome assessment } \\
\text { All outcomes }\end{array}$ & Unclear risk & Not reported \\
\hline $\begin{array}{l}\text { Attrition: incomplete outcome data } \\
\text { All outcomes }\end{array}$ & Low risk & $\%$ analysed: $45 / 49(92 \%)$ for pain outcomes \\
\hline Reporting: unreported outcomes & Unclear risk & Adverse events were not reported \\
\hline Other: anything else & High risk & $\begin{array}{l}\text { Nulliparous women were excluded from the study. Women with } \\
\text { no endocervical disease and lesions of less than 3 cm were eligible } \\
\text { "Four of the original } 49 \text { study patients were excluded from the } \\
\text { final data analysis since they recorded a higher pain score prior } \\
\text { to the procedure than after the procedure and therefore recorded } \\
\text { a negative pain score for unexplained reasons. This included } 2 \\
\text { patients in the control group and 2 patients in the study group" }\end{array}$ \\
\hline
\end{tabular}

\section{Sarkar 1993}

\begin{tabular}{ll}
\hline Methods & Prospective, random allocation, double-blind, placebo-controlled trial \\
\hline Participants & $\begin{array}{l}\text { Women were undergoing laser treatment for CIN in the colposcopy and laser clinic. } 35 \\
\text { women were allocated to receive EMLA cream (intervention group) and } 35 \text { to receive } \\
\text { placebo cream (comparison group). The following exclusion criteria were used: known } \\
\text { or suspected hypersensitivity to local anaesthetics of amide type, concomitant treatment } \\
\text { with analgesic medication, inability to complete assessment forms and patient's refusal } \\
\text { to be recruited into the trial } \\
\text { Age: mean (SD) (intervention vs. comparison): } 27.8 \text { years (6.3) vs. 28 years (5.4) }\end{array}$ \\
\hline
\end{tabular}

Interventions

The EMLA and placebo creams were supplied in visually identical metal tubes that were identified by patient number. 10 minutes before the start of the laser treatment, $10 \mathrm{~mL}$ of cream was applied to the cervix and surrounding area

Outcomes

The severity of the pain experienced during the treatment was assessed at the end of the treatment, using McGill's pain questionnaire (Melzack 1975), and the VAS (Huskisson 1983). Blood loss during the procedure was reported as none, mild, moderate and troublesome

Notes

Minor adverse experiences during treatment such as feeling hot, sweating, dizziness, fainting and sickness were not included in analysis

\section{Risk of bias}

\begin{tabular}{lll}
\hline Bias & Authors' judgement & Support for judgement \\
\hline Allocation: sequence generation & Unclear risk & Not reported \\
\hline Allocation: sequence concealment & Unclear risk & Not reported
\end{tabular}

Pain relief for women with cervical intraepithelial neoplasia undergoing colposcopy treatment (Review) 
Sarkar 1993 (Continued)

\begin{tabular}{|c|c|c|}
\hline $\begin{array}{l}\text { Performance and detection: blinding } \\
\text { All outcomes }\end{array}$ & Low risk & $\begin{array}{l}\text { "The EMLA and the placebo cream were } \\
\text { supplied in visually identical metal tubes } \\
\text { which were identified by patient number" }\end{array}$ \\
\hline $\begin{array}{l}\text { Detection: blind outcome assessment } \\
\text { All outcomes }\end{array}$ & Unclear risk & Not reported \\
\hline $\begin{array}{l}\text { Attrition: incomplete outcome data } \\
\text { All outcomes }\end{array}$ & Low risk & $\begin{array}{l}\% \text { analysed: } 68 / 70(97 \%) \text { for pattern of } \\
\text { pain outcome }\end{array}$ \\
\hline Reporting: unreported outcomes & Low risk & $\begin{array}{l}\text { Pertinent outcomes were reported in the } \\
\text { trial }\end{array}$ \\
\hline Other: anything else & High risk & $\begin{array}{l}\text { "When expressing the 'present pain inten- } \\
\text { sity', some patients indicated a score be- } \\
\text { tween categories, so extra categories were } \\
\text { created, such as } 1-5,2.5 \text { etc". Such anal- } \\
\text { yses are therefore dubious. Furthermore, } \\
\text { "When patients were asked to describe their } \\
\text { present pain by choosing specific words } \\
\text { from } \\
\text { McGill's pain questionnaire (Melzack, } \\
1975) \text {, the EMLA treated group tended } \\
\text { to select words from fewer categories. The } \\
\text { average number of words selected by the } \\
\text { EMLA group was } 3.83 \text {, compared with } 5 \text {. } \\
06 \text { for the placebo group (P < } 0.05) \text { ". This } \\
\text { probably applies to an average ordinal score } \\
\text { rating rather than average number of words } \\
\text { chosen, but this was unclear }\end{array}$ \\
\hline
\end{tabular}

Winters 2009

\begin{tabular}{|c|c|}
\hline Methods & $\begin{array}{l}\text { RCT } \\
\text { Setting: colposcopy clinic }\end{array}$ \\
\hline Participants & $\begin{array}{l}60 \text { women scheduled to have LLETZ carried out for CIN were recruited to have the } \\
\text { anaesthetic injection in the cervix before procedure by } 2 \text { different techniques } \\
\text { Referral smear (intervention vs. control): mild: } 8 / 32 \text { vs. } 5 / 32 \text {; moderate: } 12 / 32 \text { vs. } 10 / \\
32 \text {; severe: } 8 / 32 \text { vs. } 7 / 32 \text {; borderline: } 2 / 32 \text { vs. } 3 / 32 \text {; inadequate: } 2 / 32 \text { vs. } 0 / 32 \text {; glandular } \\
\text { abnormality: } 0 / 32 \text { vs. } 1 / 32 \\
\text { LLETZ histology: CIN } 1 \text { : } 5 / 32 \text { vs. } 1 / 32 \text {; CIN } 2 \text { : } 7 / 32 \text { vs. } 7 / 32 \text {; CIN } 3: 15 / 32 \text { vs. } 17 / \\
32 \text {; inflammation: } 3 / 32 \text { vs. } 0 / 32 \text {; CGIN: } 2 / 32 \text { vs. } 0 / 32 \text {; adenocarcinoma: } 0 / 32 \text { vs. } 1 / 32 \\
\text { Margins: both negative: } 24 / 32(75 \%) \text { vs. } 17 / 32(65 \%) \text {; } \\
\text { positive endocervical margin: } 0 / 32 \text { vs. } 2 / 32 \text {; } \\
\text { positive ectocervical margin: } 5 / 32 \text { vs. } 6 / 32 \\
\text { Both positive: } 1 / 32 \text { vs. } 0 / 32 \\
\text { Uncertain: } 2 / 32 \text { vs. } 1 / 32\end{array}$ \\
\hline
\end{tabular}

Pain relief for women with cervical intraepithelial neoplasia undergoing colposcopy treatment (Review) 
Winters 2009 (Continued)

\begin{tabular}{ll}
\hline Interventions & $\begin{array}{l}\text { Both groups received a total of } 8.8 \mathrm{~mL} \text { ( } 4 \text { ampoules) of prilocaine } 3 \% \text { with felypressin } \\
\text { (Citanest, AstraZeneca, UK). The control group received four } 2.2 \mathrm{~mL} \text { ampoules of }\end{array}$ \\
prilocaine with felypressin injected deep into the cervical stroma at 8 equally spaced \\
points around the circumference of the cervical TZ, using a 35 -mm 27 -gauge dental \\
needle. In the intervention group the injection technique differed in that one $2.2 \mathrm{~mL}$ \\
ampoule of prilocaine with felypressin was injected just under the epithelium, in 4 areas \\
circumferentially, in order to raise a blanch. Then three $2.2 \mathrm{~mL}$ ampoules were injected \\
in 8 places circumferentially deep into the cervical stroma
\end{tabular}

Outcomes

Following completion of treatment, women were asked to indicate on separate 100mm VAS the pain they experienced during administration of local anaesthetic and then during the actual LLETZ procedure

\begin{tabular}{|c|c|c|}
\hline Notes & \multicolumn{2}{|l|}{ - } \\
\hline \multicolumn{3}{|l|}{ Risk of bias } \\
\hline Bias & Authors' judgement & Support for judgement \\
\hline Allocation: sequence generation & Low risk & $\begin{array}{l}\text { "The block randomisation code was computer gener- } \\
\text { ated" }\end{array}$ \\
\hline Allocation: sequence concealment & Low risk & $\begin{array}{l}\text { "Randomisation was performed by opening sequen- } \\
\text { tially numbered, sealed envelopes in order of recruit- } \\
\text { ment" }\end{array}$ \\
\hline $\begin{array}{l}\text { Performance and detection: blinding } \\
\text { All outcomes }\end{array}$ & High risk & $\begin{array}{l}\text { "Participants were blinded to the technique of admin- } \\
\text { istration of local anaesthetic, by necessity the colpo- } \\
\text { scopist could not be blinded to this" }\end{array}$ \\
\hline $\begin{array}{l}\text { Detection: blind outcome assessment } \\
\text { All outcomes }\end{array}$ & Unclear risk & Not reported \\
\hline $\begin{array}{l}\text { Attrition: incomplete outcome data } \\
\text { All outcomes }\end{array}$ & Low risk & $\%$ analysed: $58 / 60(\%)$ \\
\hline Reporting: unreported outcomes & High risk & Adverse events of injections were not reported \\
\hline Other: anything else & Low risk & No additional form of bias was likely \\
\hline
\end{tabular}

CGIN: cervical glandular intraepithelial neoplasia; CIN: cervical intraepithelial neoplasia; HAD: Hospital Anxiety and Depression scale; HPV: human papillomavirus; LLETZ: large loop excision of the transformation zone; RCT: randomised controlled trial; SD: standard deviation; TENS: transcutaneous electric nerve stimulation; TZ: transformation zone; VAS: visual analogue scale; VRS: verbal rating score. 
Characteristics of excluded studies [ordered by study ID]

\begin{tabular}{ll}
\hline Study & Reason for exclusion \\
\hline Sarkar 1990 & Not an RCT \\
\hline Sharp 2009 & Pain relief interventions were not part of trial scope \\
\hline
\end{tabular}

RCT: randomised controlled trial. 
DATA ANDANALYSES

Comparison 1. Local anaesthetic (lignocaine 2\%) injection versus control (saline injection)

\begin{tabular}{lcccc} 
Outcome or subgroup title & $\begin{array}{c}\text { No. of } \\
\text { studies }\end{array}$ & $\begin{array}{c}\text { No. of } \\
\text { participants }\end{array}$ & Statistical method & Effect size \\
\hline $\begin{array}{l}\text { 1 Pain scores during procedure } \\
\text { (VAS) }\end{array}$ & 2 & 130 & Mean Difference (IV, Random, 95\% CI) & $-13.74[-34.32,6$. \\
$\quad \begin{array}{l}1.1 \text { Paracervical block versus } \\
\text { placebo }\end{array}$ & 1 & 70 & Mean Difference (IV, Random, 95\% CI) & $-3.0[-16.03,10.03]$ \\
$\begin{array}{l}1.2 \text { Direct cervical infiltration } \\
\text { versus placebo }\end{array}$ & 1 & 60 & Mean Difference (IV, Random, 95\% CI) & $-24.0[-35.44,-12$. \\
2 Moderate to severe pain & 1 & & Risk Ratio (IV, Random, 95\% CI) & S6] \\
\hline
\end{tabular}

Comparison 2. Local anaesthetic plus vasoconstrictor versus control

\begin{tabular}{|c|c|c|c|c|}
\hline Outcome or subgroup title & $\begin{array}{l}\text { No. of } \\
\text { studies }\end{array}$ & $\begin{array}{c}\text { No. of } \\
\text { participants }\end{array}$ & Statistical method & Effect size \\
\hline $\begin{array}{l}1 \text { Pain scores during procedure } \\
\text { (VAS: } 0-100)\end{array}$ & 2 & 95 & Mean Difference (IV, Random, 95\% CI) & $\begin{array}{l}-23.73[-37.53,-9 . \\
93]\end{array}$ \\
\hline 1.1 Lignocaine plus adrenaline & 1 & 45 & Mean Difference (IV, Random, 95\% CI) & $\begin{array}{l}-31.10[-43.74,-18 . \\
46]\end{array}$ \\
\hline 1.2 Prilocaine plus felypressin & 1 & 50 & Mean Difference (IV, Random, 95\% CI) & $-17.0[-28.19,-5.81]$ \\
\hline 2 Moderate or severe pain & 2 & & Risk Ratio (IV, Random, 95\% CI) & Subtotals only \\
\hline 2.1 versus placebo & 1 & 92 & Risk Ratio (IV, Random, 95\% CI) & $0.12[0.04,0.37]$ \\
\hline 2.2 versus no treatment & 1 & 50 & Risk Ratio (IV, Random, 95\% CI) & $0.73[0.42,1.27]$ \\
\hline 3 Troublesome bleeding & 1 & & Risk Ratio (IV, Random, 95\% CI) & Subtotals only \\
\hline
\end{tabular}

Comparison 3. Local anaesthetic plus vasoconstrictor versus local anaesthetic injection alone

\begin{tabular}{|c|c|c|c|c|}
\hline Outcome or subgroup title & $\begin{array}{l}\text { No. of } \\
\text { studies }\end{array}$ & $\begin{array}{c}\text { No. of } \\
\text { participants }\end{array}$ & Statistical method & Effect size \\
\hline 1 Moderate or severe pain & 1 & & Risk Ratio (IV, Random, 95\% CI) & Subtotals only \\
\hline 2 Blood loss (volume) & 1 & & Mean Difference (IV, Random, 95\% CI) & Subtotals only \\
\hline 3 Duration of treatment & 1 & & Mean Difference (IV, Random, 95\% CI) & Subtotals only \\
\hline
\end{tabular}

Pain relief for women with cervical intraepithelial neoplasia undergoing colposcopy treatment (Review) 
Comparison 4. Prilocaine plus felypressin versus lignocaine plus adrenaline

\begin{tabular}{lcccc} 
Outcome or subgroup title & $\begin{array}{c}\text { No. of } \\
\text { studies }\end{array}$ & $\begin{array}{c}\text { No. of } \\
\text { participants }\end{array}$ & Statistical method & Effect size \\
\hline 1 Pain (using 6 category scale) & 1 & Mean Difference (IV, Random, 95\% CI) & Subtotals only \\
2 Blood loss (0-5 scale) & 1 & Mean Difference (IV, Random, 95\% CI) & Subtotals only \\
\hline
\end{tabular}

Comparison 5. Deep plus superficial versus deep cervical injection

\begin{tabular}{|c|c|c|c|c|}
\hline Outcome or subgroup title & $\begin{array}{l}\text { No. of } \\
\text { studies }\end{array}$ & $\begin{array}{c}\text { No. of } \\
\text { participants }\end{array}$ & Statistical method & Effect size \\
\hline $\begin{array}{l}1 \text { Pain scores during procedure } \\
\text { (VAS: } 0-100)\end{array}$ & 1 & & Mean Difference (IV, Random, 95\% CI) & Subtotals only \\
\hline
\end{tabular}

Comparison 6. Oral analgesic versus control

\begin{tabular}{lccll} 
Outcome or subgroup title & $\begin{array}{c}\text { No. of } \\
\text { studies }\end{array}$ & $\begin{array}{c}\text { No. of } \\
\text { participants }\end{array}$ & \multicolumn{1}{c}{ Statistical method } & Effect size \\
\hline 1 Pain scores (VAS: 0-100) & 2 & & Mean Difference (IV, Random, 95\% CI) & Subtotals only \\
$\quad 1.1$ versus placebo & 2 & 129 & Mean Difference (IV, Random, 95\% CI) & $-3.51[-10.03,3.01]$ \\
$\quad 1.2$ versus no treatment & 1 & 32 & Mean Difference (IV, Random, 95\% CI) & $-4.0[-13.69,5.69]$ \\
$\begin{array}{l}\text { 2 Moderate to severe pain } \\
\text { 3 Pain relief required in first 24 }\end{array}$ & 1 & & Risk Ratio (IV, Random, 95\% CI) & Subtotals only \\
$\quad$ hours & 1 & & Risk Ratio (IV, Random, 95\% CI) & Subtotals only \\
\hline
\end{tabular}

Comparison 7. Inhalation analgesia versus placebo

\begin{tabular}{|c|c|c|c|c|}
\hline Outcome or subgroup title & $\begin{array}{l}\text { No. of } \\
\text { studies }\end{array}$ & $\begin{array}{c}\text { No. of } \\
\text { participants }\end{array}$ & Statistical method & Effect size \\
\hline 1 Pain scores (VAS: $0-100)$ & 1 & & Mean Difference (IV, Random, 95\% CI) & Subtotals only \\
\hline 2 Heavy vaginal bleeding & 1 & & Risk Ratio (IV, Random, 95\% CI) & Subtotals only \\
\hline 3 Anxiety - HAD score & 1 & & Mean Difference (IV, Random, 95\% CI) & Subtotals only \\
\hline
\end{tabular}




\begin{tabular}{|c|c|c|c|c|}
\hline Outcome or subgroup title & $\begin{array}{l}\text { No. of } \\
\text { studies }\end{array}$ & $\begin{array}{c}\text { No. of } \\
\text { participants }\end{array}$ & Statistical method & Effect size \\
\hline $\begin{array}{l}1 \text { Pain scores during procedure } \\
\quad \text { (VAS: } 0-100)\end{array}$ & 1 & & Mean Difference (IV, Random, 95\% CI) & Subtotals only \\
\hline 2 Duration of treatment & 1 & & Mean Difference (IV, Random, 95\% CI) & Subtotals only \\
\hline
\end{tabular}

Comparison 9. Cocaine spray versus placebo

\begin{tabular}{|c|c|c|c|c|}
\hline Outcome or subgroup title & $\begin{array}{l}\text { No. of } \\
\text { studies }\end{array}$ & $\begin{array}{c}\text { No. of } \\
\text { participants }\end{array}$ & Statistical method & Effect size \\
\hline $\begin{array}{l}1 \text { Pain scores during procedure } \\
\text { (VAS: } 0-100)\end{array}$ & 1 & & Mean Difference (IV, Random, 95\% CI) & Subtotals only \\
\hline 2 Moderate to severe pain & 1 & & Risk Ratio (IV, Random, 95\% CI) & Subtotals only \\
\hline 3 Troublesome bleeding & 1 & & Risk Ratio (IV, Random, 95\% CI) & Subtotals only \\
\hline
\end{tabular}

Comparison 10. TENS versus TENS plus local anaesthetic injection

\begin{tabular}{lcccc} 
Outcome or subgroup title & $\begin{array}{c}\text { No. of } \\
\text { studies }\end{array}$ & $\begin{array}{c}\text { No. of } \\
\text { participants }\end{array}$ & Statistical method & Effect size \\
\hline 1 Troublesome blood loss & 1 & & Risk Ratio (IV, Random, 95\% CI) & Subtotals only \\
\hline
\end{tabular}

Comparison 11. TENS versus local anaesthetic injection

\begin{tabular}{lcccc} 
Outcome or subgroup title & $\begin{array}{c}\text { No. of } \\
\text { studies }\end{array}$ & $\begin{array}{c}\text { No. of } \\
\text { participants }\end{array}$ & Statistical method & Effect size \\
\hline 1 Troublesome blood loss & 1 & & Risk Ratio (IV, Random, 95\% CI) & Subtotals only \\
\hline
\end{tabular}


Comparison 12. TENS plus local versus local anaesthetic injection

\begin{tabular}{lcccc} 
Outcome or subgroup title & $\begin{array}{c}\text { No. of } \\
\text { studies }\end{array}$ & $\begin{array}{c}\text { No. of } \\
\text { participants }\end{array}$ & Statistical method & Effect size \\
\hline 1 Troublesome blood loss & 1 & & Risk Ratio (IV, Random, 95\% CI) & Subtotals only \\
\hline
\end{tabular}

\section{Analysis I.I. Comparison I Local anaesthetic (lignocaine 2\%) injection versus control (saline injection), Outcome I Pain scores during procedure (VAS).}

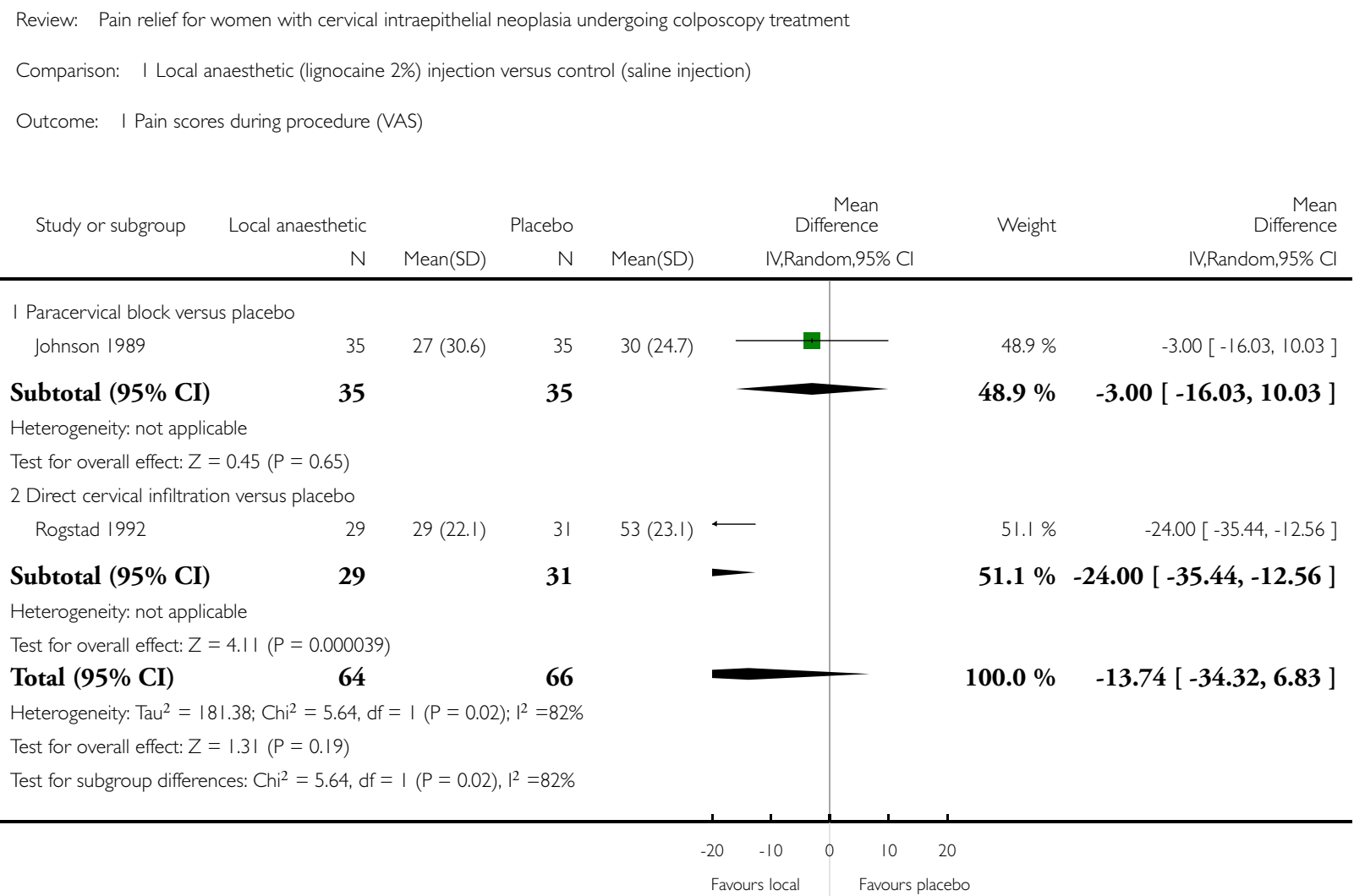


Analysis I.2. Comparison I Local anaesthetic (lignocaine 2\%) injection versus control (saline injection), Outcome 2 Moderate to severe pain.

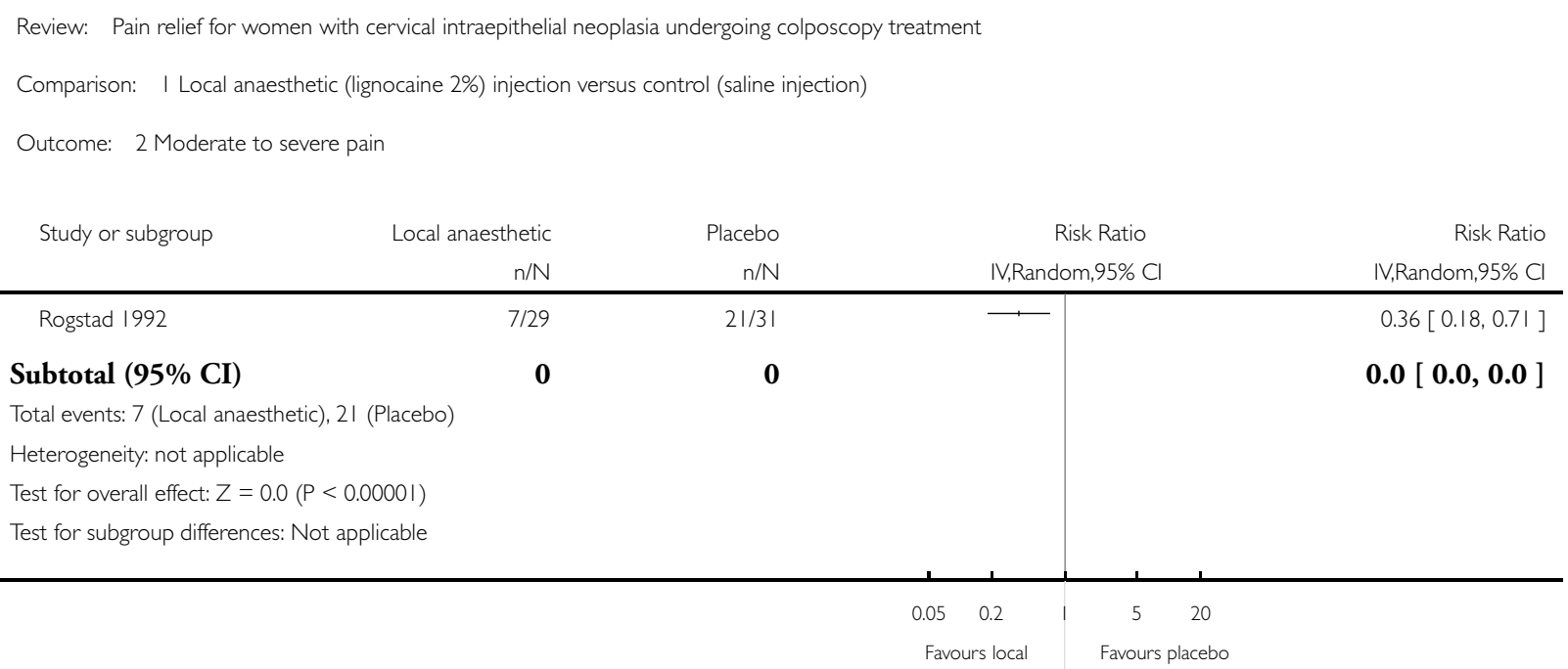


Analysis 2.I. Comparison 2 Local anaesthetic plus vasoconstrictor versus control, Outcome I Pain scores during procedure (VAS: $0-100)$.

Review: Pain relief for women with cervical intraepithelial neoplasia undergoing colposcopy treatment

Comparison: 2 Local anaesthetic plus vasoconstrictor versus control

Outcome: I Pain scores during procedure (VAS: 0-100)

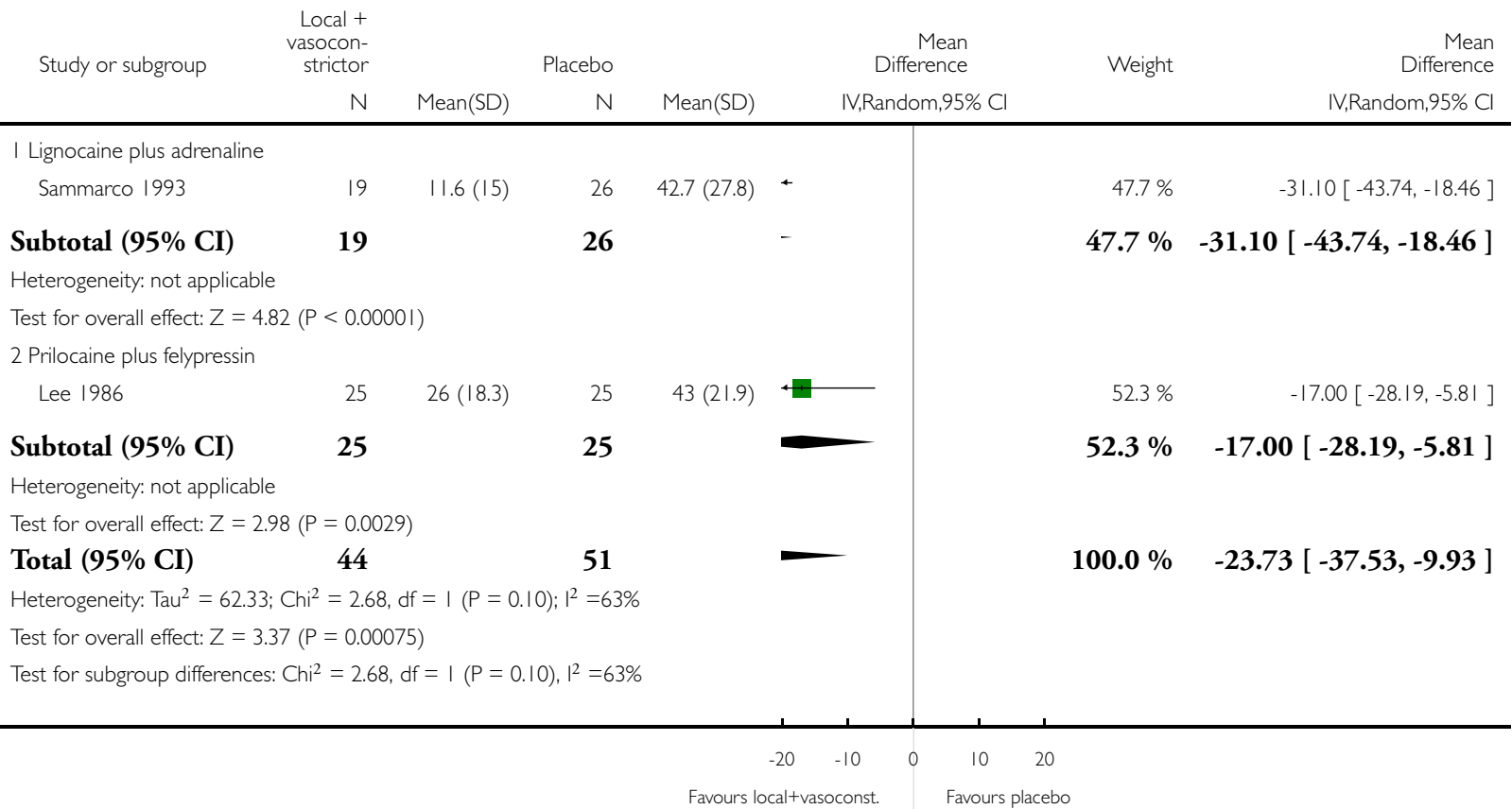


Analysis 2.2. Comparison 2 Local anaesthetic plus vasoconstrictor versus control, Outcome 2 Moderate or severe pain.

Review: Pain relief for women with cervical intraepithelial neoplasia undergoing colposcopy treatment

Comparison: 2 Local anaesthetic plus vasoconstrictor versus control

Outcome: 2 Moderate or severe pain

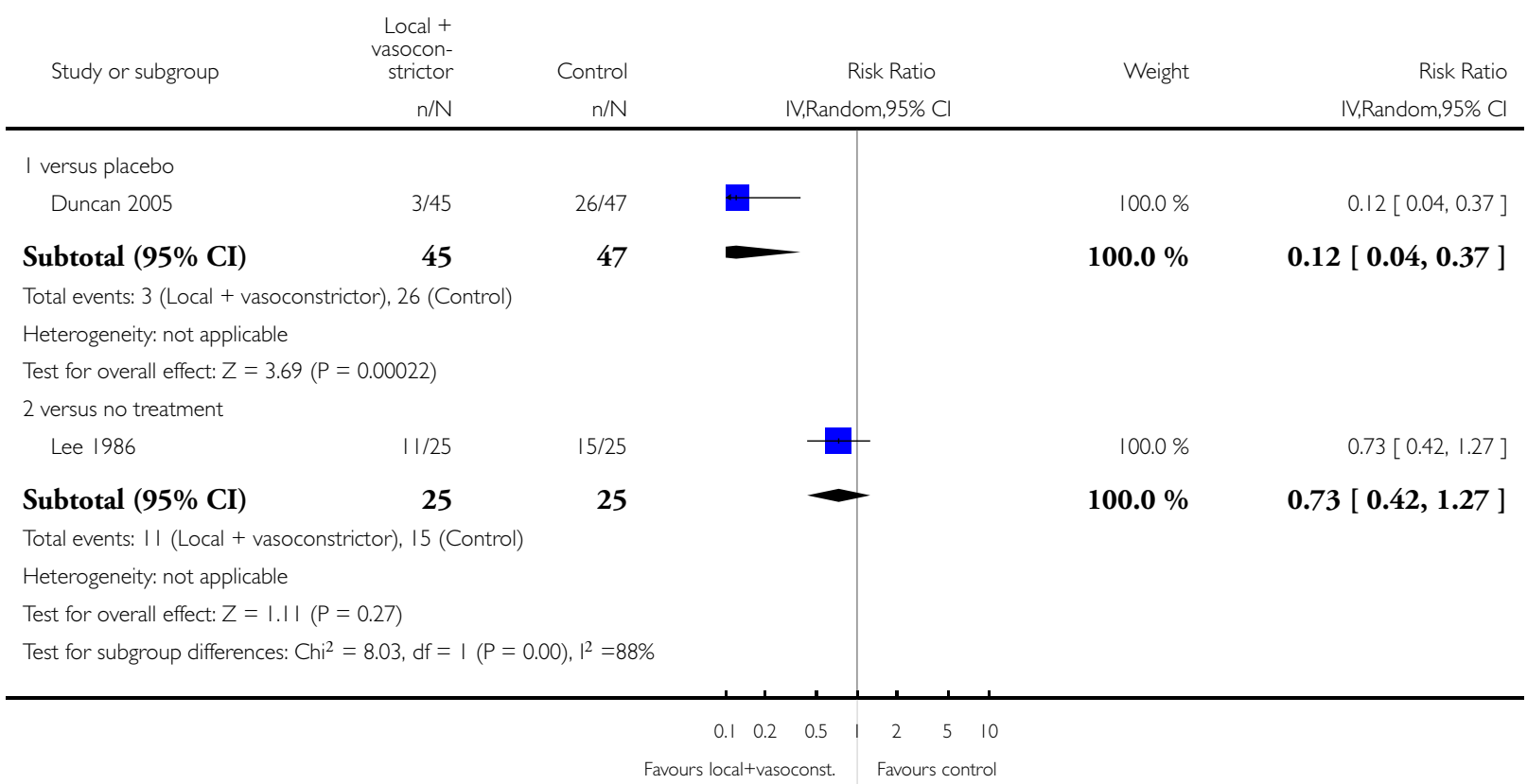


Analysis 2.3. Comparison 2 Local anaesthetic plus vasoconstrictor versus control, Outcome 3 Troublesome bleeding.

Review: Pain relief for women with cervical intraepithelial neoplasia undergoing colposcopy treatment

Comparison: 2 Local anaesthetic plus vasoconstrictor versus control

Outcome: 3 Troublesome bleeding

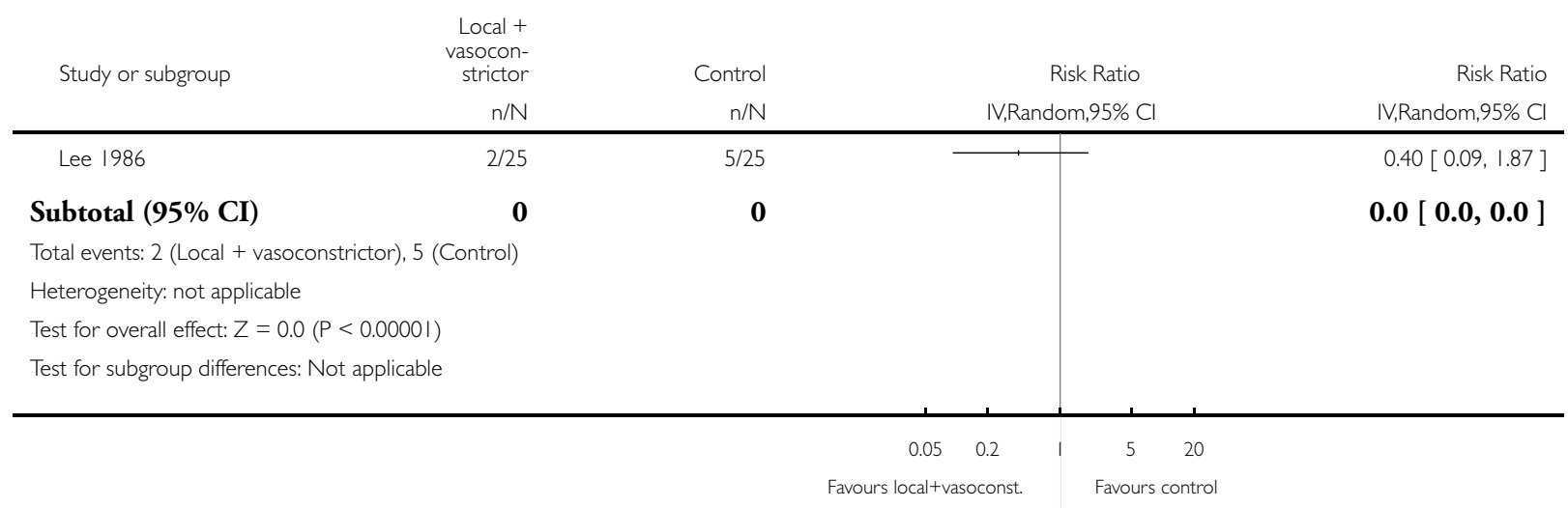

Analysis 3.I. Comparison 3 Local anaesthetic plus vasoconstrictor versus local anaesthetic injection alone, Outcome I Moderate or severe pain.

Review: Pain relief for women with cervical intraepithelial neoplasia undergoing colposcopy treatment

Comparison: 3 Local anaesthetic plus vasoconstrictor versus local anaesthetic injection alone

Outcome: I Moderate or severe pain

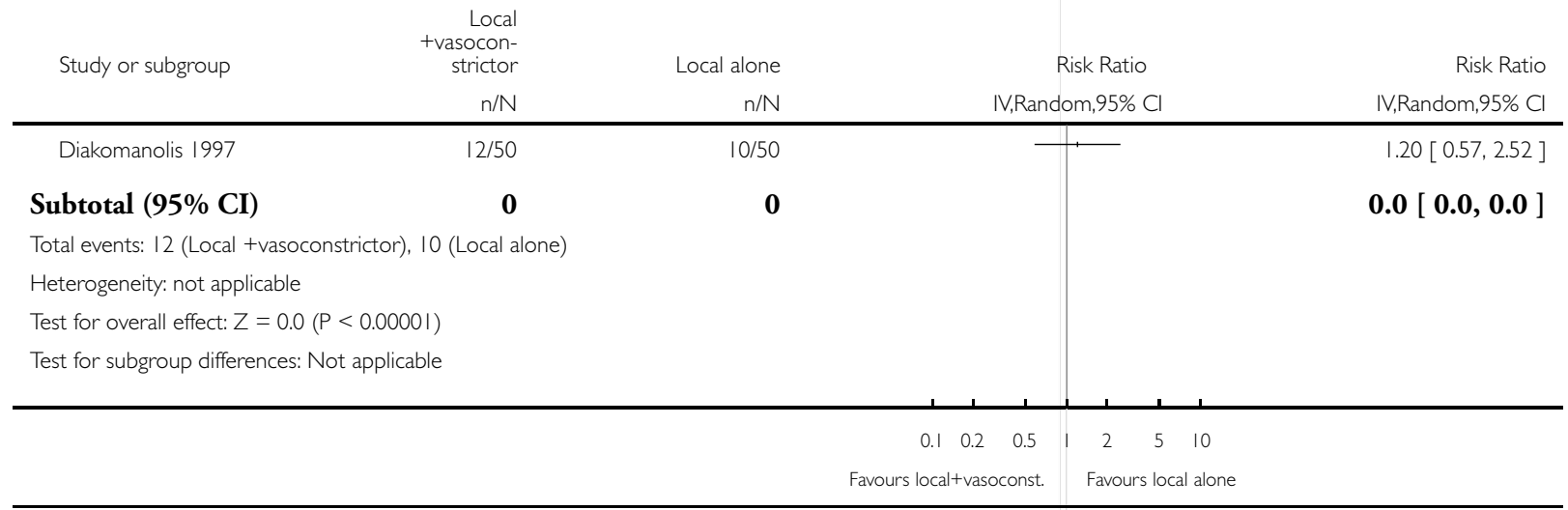

Pain relief for women with cervical intraepithelial neoplasia undergoing colposcopy treatment (Review)

Copyright ( 2012 The Cochrane Collaboration. Published by John Wiley \& Sons, Ltd. 
Analysis 3.2. Comparison 3 Local anaesthetic plus vasoconstrictor versus local anaesthetic injection alone, Outcome 2 Blood loss (volume).

\footnotetext{
Review: Pain relief for women with cervical intraepithelial neoplasia undergoing colposcopy treatment

Comparison: 3 Local anaesthetic plus vasoconstrictor versus local anaesthetic injection alone

Outcome: 2 Blood loss (volume)
}

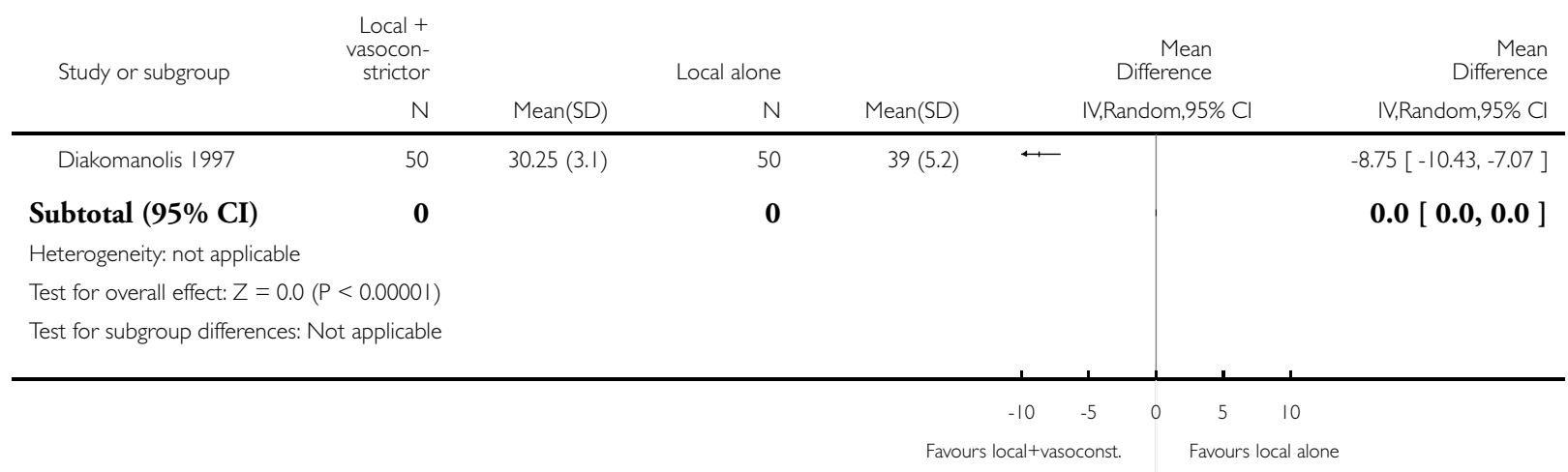


Analysis 3.3. Comparison 3 Local anaesthetic plus vasoconstrictor versus local anaesthetic injection alone, Outcome 3 Duration of treatment.

Review: Pain relief for women with cervical intraepithelial neoplasia undergoing colposcopy treatment

Comparison: 3 Local anaesthetic plus vasoconstrictor versus local anaesthetic injection alone

Outcome: 3 Duration of treatment

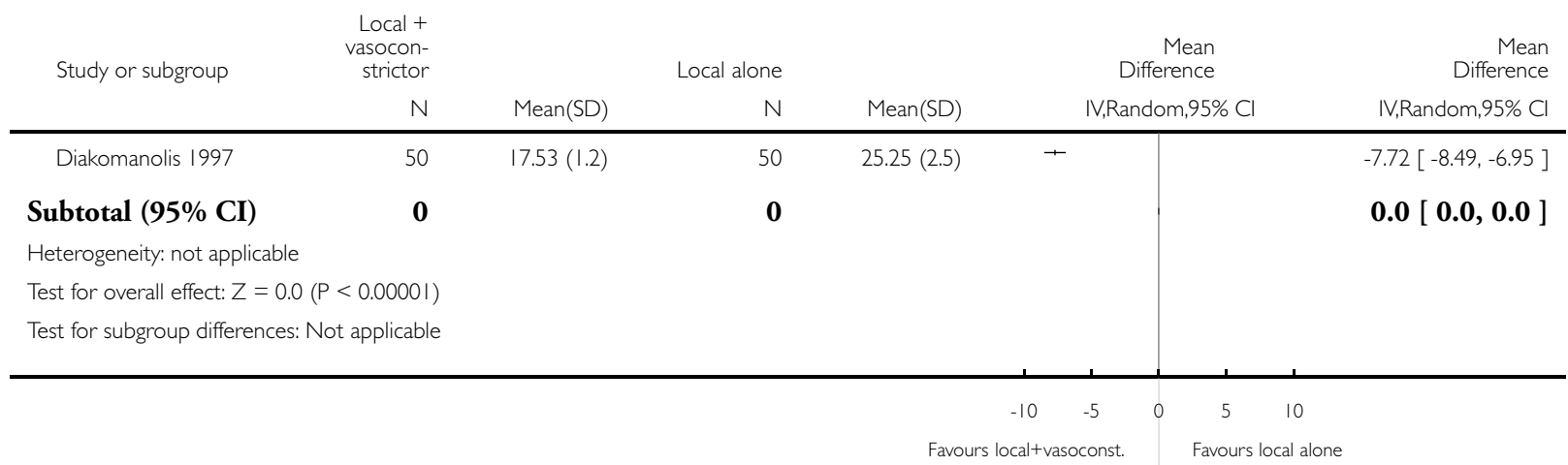

Analysis 4.I. Comparison 4 Prilocaine plus felypressin versus lignocaine plus adrenaline, Outcome I Pain (using 6 category scale).

Review: Pain relief for women with cervical intraepithelial neoplasia undergoing colposcopy treatment

Comparison: 4 Prilocaine plus felypressin versus lignocaine plus adrenaline

Outcome: I Pain (using 6 category scale)

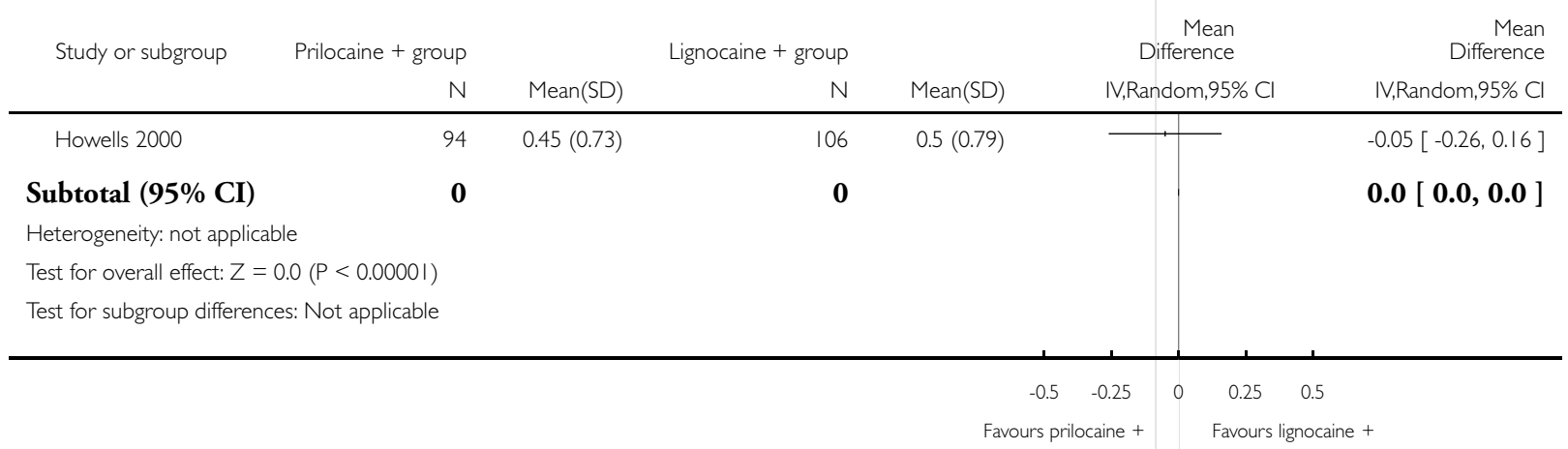

Pain relief for women with cervical intraepithelial neoplasia undergoing colposcopy treatment (Review)

Copyright @ 2012 The Cochrane Collaboration. Published by John Wiley \& Sons, Ltd. 
Analysis 4.2. Comparison 4 Prilocaine plus felypressin versus lignocaine plus adrenaline, Outcome 2 Blood loss (0-5 scale).

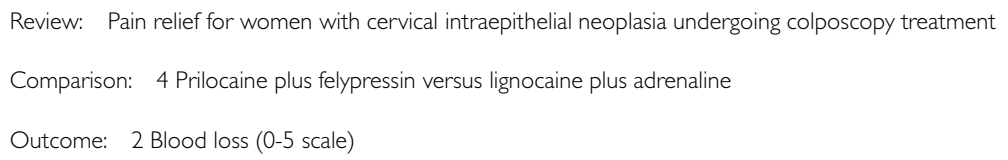

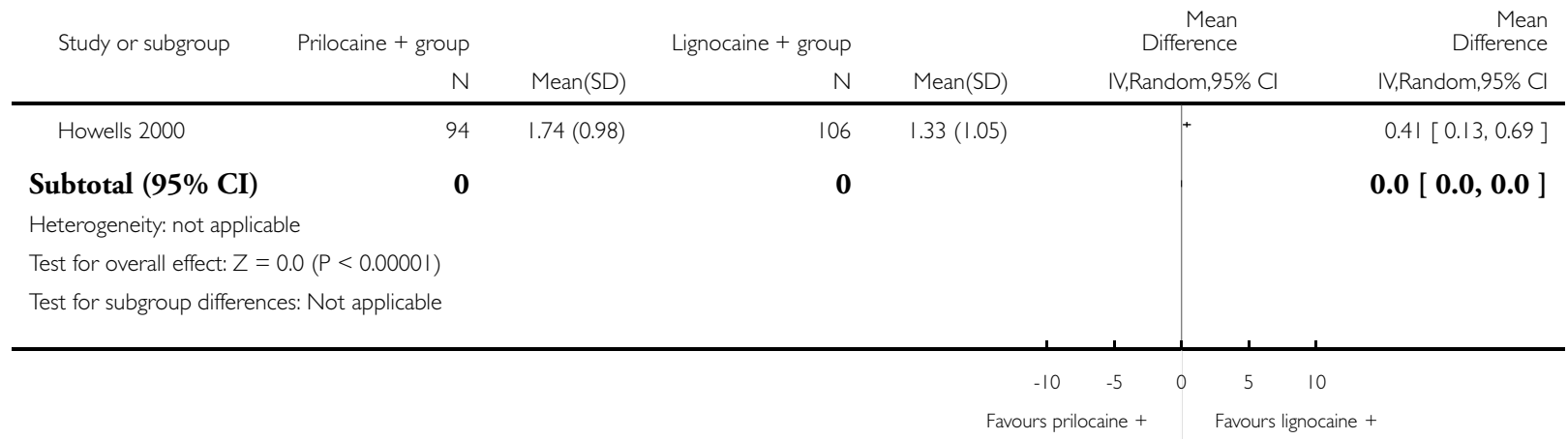

\section{Analysis 5.I. Comparison 5 Deep plus superficial versus deep cervical injection, Outcome I Pain scores during procedure (VAS: $0-100)$.}

Review: Pain relief for women with cervical intraepithelial neoplasia undergoing colposcopy treatment

Comparison: 5 Deep plus superficial versus deep cervical injection

Outcome: I Pain scores during procedure (VAS: 0-100)

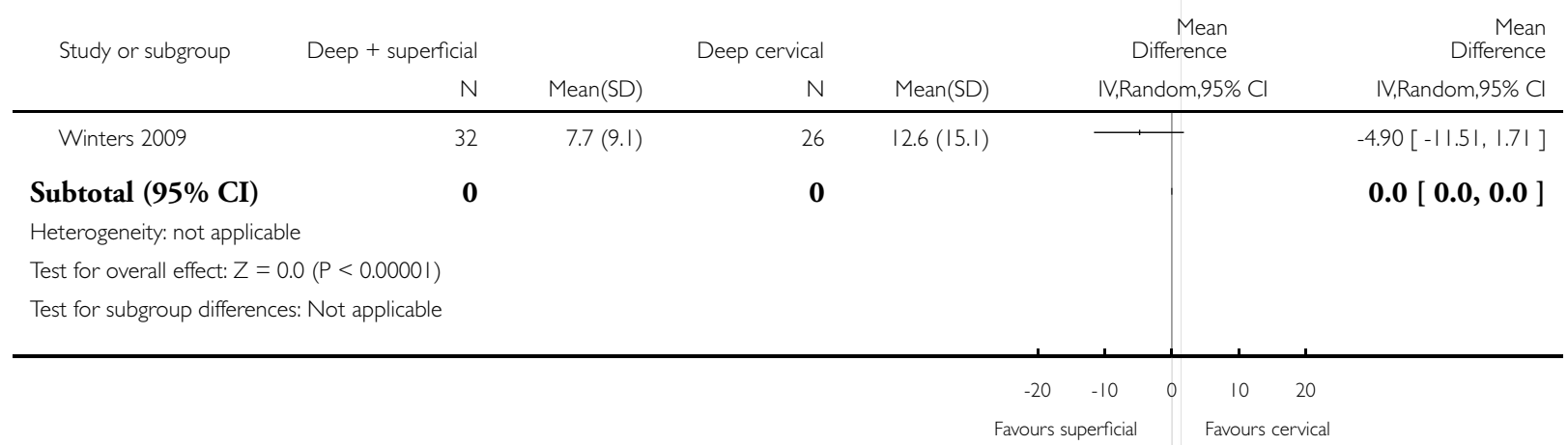


Analysis 6.I. Comparison 6 Oral analgesic versus control, Outcome I Pain scores (VAS: 0-100).

Review: Pain relief for women with cervical intraepithelial neoplasia undergoing colposcopy treatment

Comparison: 6 Oral analgesic versus control

Outcome: I Pain scores (VAS: 0-100)

\begin{tabular}{|c|c|c|c|c|c|c|c|c|c|}
\hline \multirow[t]{2}{*}{ Study or subgroup } & \multirow{2}{*}{$\begin{array}{r}\text { Oral analgesic } \\
N\end{array}$} & \multicolumn{3}{|c|}{ Placebo } & \multicolumn{3}{|c|}{$\begin{array}{r}\text { Mean } \\
\text { Difference }\end{array}$} & \multirow[t]{2}{*}{ Weight } & \multirow{2}{*}{$\begin{array}{r}\text { Mean } \\
\text { Difference } \\
\text { IV,Random,95\% C }\end{array}$} \\
\hline & & Mean(SD) & $N$ & Mean(SD) & & IV,Rando & $\mathrm{om}, 95 \% \mathrm{Cl}$ & & \\
\hline \multicolumn{10}{|l|}{ I versus placebo } \\
\hline Al Kurdi 1985 & 50 & $36(23.1)$ & 47 & $41(23.1)$ & & & & $50.2 \%$ & $-5.00[-14.20,4.20]$ \\
\hline Frega 1994 & 11 & $19(13)$ & 21 & $21(12)$ & & & & $49.8 \%$ & $-2.00[-11.24,7.24]$ \\
\hline Subtotal $(95 \% \mathrm{CI})$ & 61 & & 68 & & & & & $100.0 \%$ & $-3.51[-10.03,3.01]$ \\
\hline \multicolumn{10}{|c|}{ Heterogeneity: $\mathrm{Tau}^{2}=0.0 ; \mathrm{Chi}^{2}=0.20, \mathrm{df}=\mathrm{I}(\mathrm{P}=0.65) ; \mathrm{I}^{2}=0.0 \%$} \\
\hline \multicolumn{10}{|c|}{ Test for overall effect: $Z=1.05(P=0.29)$} \\
\hline \multicolumn{10}{|l|}{2 versus no treatment } \\
\hline Frega 1994 & 11 & $19(13)$ & 21 & $23(13.8)$ & & & & $100.0 \%$ & $-4.00[-13.69,5.69]$ \\
\hline Subtotal (95\% CI) & 11 & & 21 & & & & & $100.0 \%$ & $-4.00[-13.69,5.69]$ \\
\hline \multicolumn{10}{|c|}{ Heterogeneity: not applicable } \\
\hline \multicolumn{10}{|c|}{ Test for overall effect: $Z=0.81(P=0.42)$} \\
\hline \multicolumn{10}{|c|}{ Test for subgroup differences: $\mathrm{Chi}^{2}=0.01, \mathrm{df}=\mathrm{I}(\mathrm{P}=0.93), \mathrm{I}^{2}=0.0 \%$} \\
\hline & & & & & -10 & -5 & 5 & 10 & \\
\hline
\end{tabular}




\section{Analysis 6.2. Comparison 6 Oral analgesic versus control, Outcome 2 Moderate to severe pain.}

Review: Pain relief for women with cervical intraepithelial neoplasia undergoing colposcopy treatment

Comparison: 6 Oral analgesic versus control

Outcome: 2 Moderate to severe pain

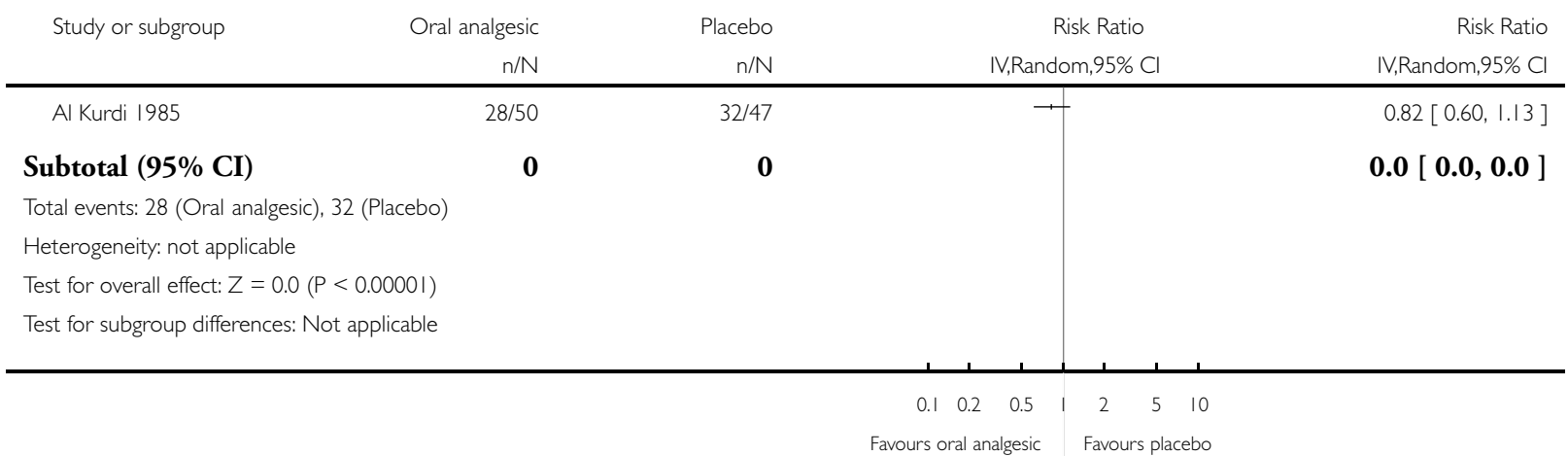

\section{Analysis 6.3. Comparison 6 Oral analgesic versus control, Outcome 3 Pain relief required in first 24 hours.}

Review: Pain relief for women with cervical intraepithelial neoplasia undergoing colposcopy treatment

Comparison: 6 Oral analgesic versus control

Outcome: 3 Pain relief required in first 24 hours

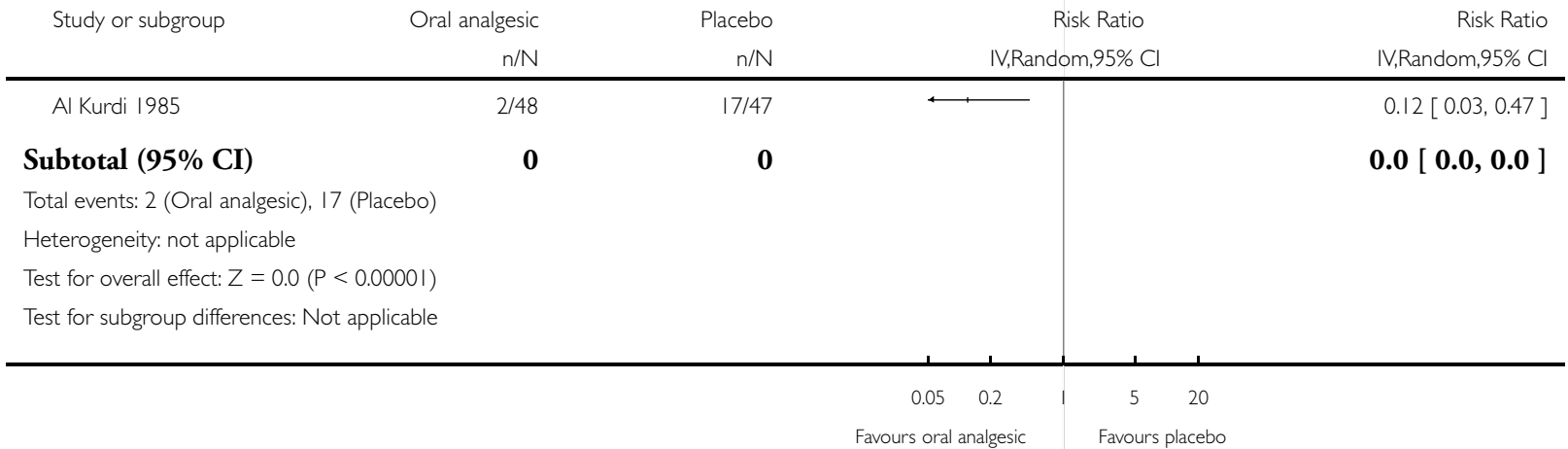


Analysis 7.I. Comparison 7 Inhalation analgesia versus placebo, Outcome I Pain scores (VAS: 0-100).

Review: Pain relief for women with cervical intraepithelial neoplasia undergoing colposcopy treatment

Comparison: 7 Inhalation analgesia versus placebo

Outcome: I Pain scores (VAS: 0-100)

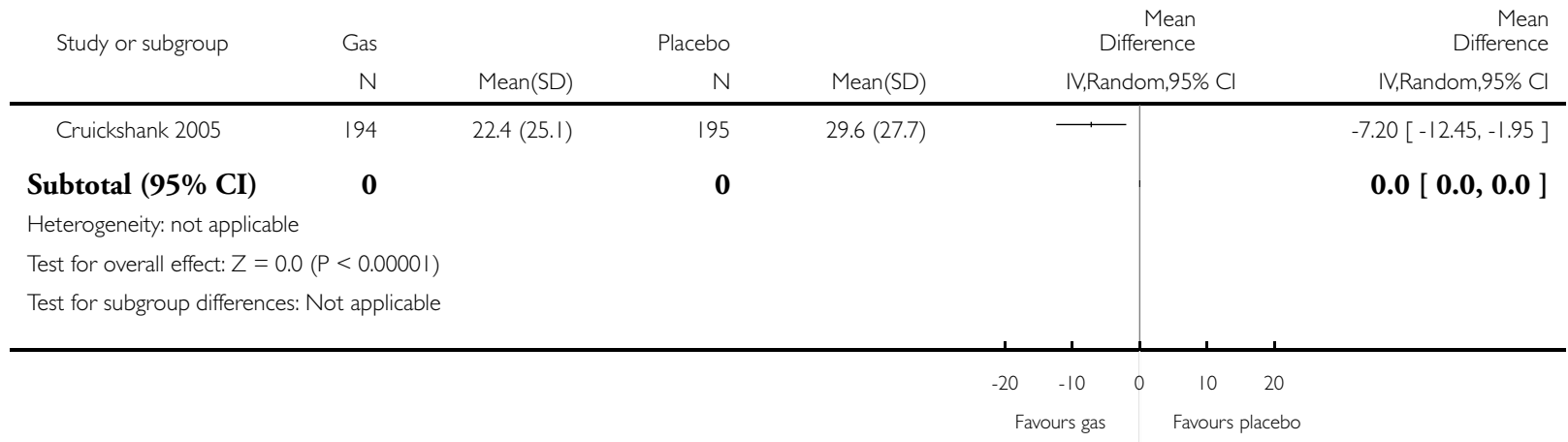

Analysis 7.2. Comparison 7 Inhalation analgesia versus placebo, Outcome 2 Heavy vaginal bleeding.

Review: Pain relief for women with cervical intraepithelial neoplasia undergoing colposcopy treatment

Comparison: 7 Inhalation analgesia versus placebo

Outcome: 2 Heavy vaginal bleeding

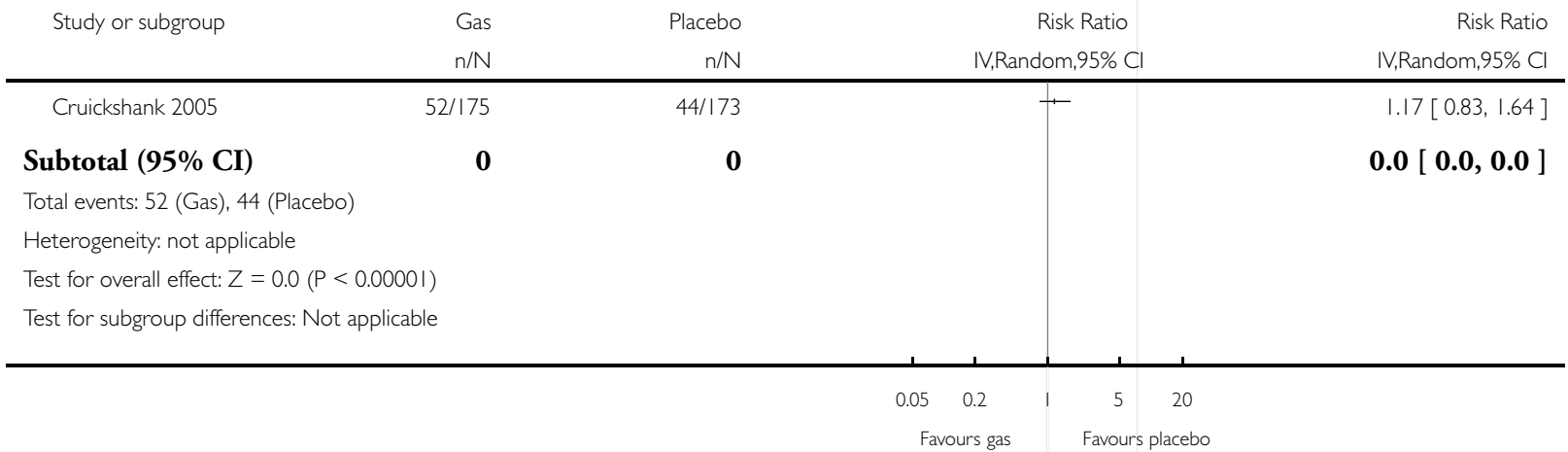




\section{Analysis 7.3. Comparison 7 Inhalation analgesia versus placebo, Outcome 3 Anxiety - HAD score.}

Review: Pain relief for women with cervical intraepithelial neoplasia undergoing colposcopy treatment

Comparison: 7 Inhalation analgesia versus placebo

Outcome: 3 Anxiety - HAD score

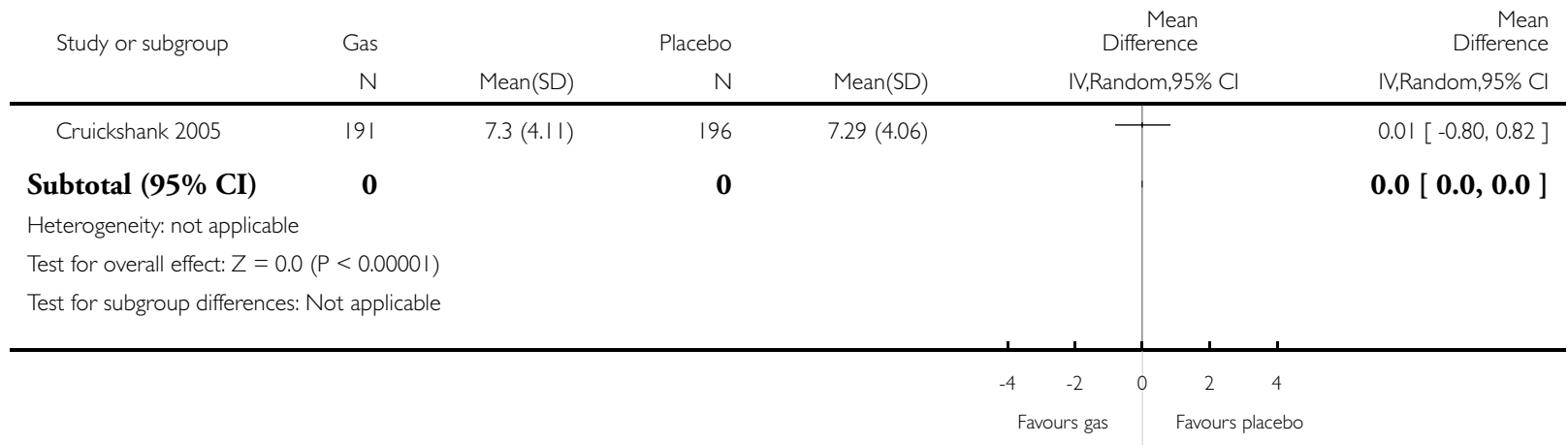

Analysis 8.I. Comparison 8 Topical application versus placebo, Outcome I Pain scores during procedure (VAS: 0-100).

Review: Pain relief for women with cervical intraepithelial neoplasia undergoing colposcopy treatment

Comparison: 8 Topical application versus placebo

Outcome: I Pain scores during procedure (VAS: 0-100)

\begin{tabular}{|c|c|c|c|c|c|c|c|c|c|}
\hline \multirow[t]{2}{*}{ Study or subgroup } & Anaesthetic gel & \multicolumn{3}{|c|}{ Placebo } & \multicolumn{4}{|c|}{$\begin{array}{r}\text { Mean } \\
\text { Difference }\end{array}$} & \multirow{2}{*}{$\begin{array}{r}\text { Mean } \\
\text { Difference } \\
\text { IV,Random,95\% Cl }\end{array}$} \\
\hline & $\mathrm{N}$ & Mean(SD) & $\mathrm{N}$ & Mean(SD) & & $\mathrm{IV}, \mathrm{R}$ & dom,95\% Cl & & \\
\hline Lipscomb 1995 & 25 & $62(82)$ & 25 & $7 \mid(\mid 28)$ & & & - & & $-9.00[-68.59,50.59]$ \\
\hline Subtotal (95\% CI) & $\mathbf{0}$ & & $\mathbf{0}$ & & & & & & $0.0[0.0,0.0]$ \\
\hline \multicolumn{10}{|l|}{ Heterogeneity: not applicable } \\
\hline \multicolumn{10}{|c|}{ Test for overall effect: $Z=0.0(P<0.0000 \mathrm{I})$} \\
\hline \multicolumn{10}{|c|}{ Test for subgroup differences: Not applicable } \\
\hline & & & & & -100 & -50 & 50 & 100 & \\
\hline
\end{tabular}




\section{Analysis 8.2. Comparison 8 Topical application versus placebo, Outcome 2 Duration of treatment.}

Review: Pain relief for women with cervical intraepithelial neoplasia undergoing colposcopy treatment

Comparison: 8 Topical application versus placebo

Outcome: 2 Duration of treatment

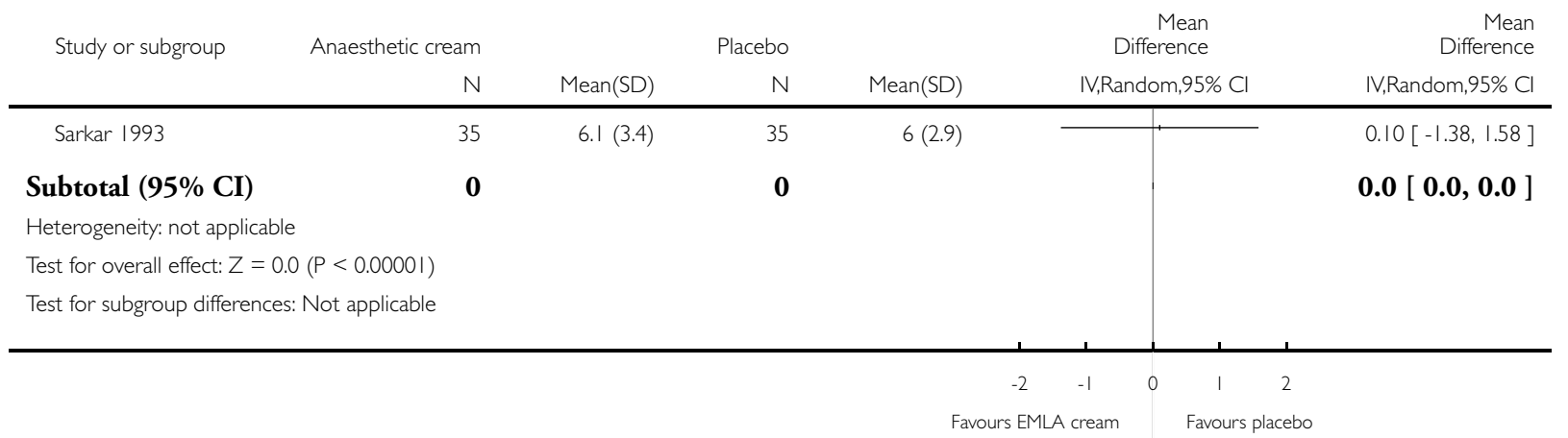

Analysis 9.1. Comparison 9 Cocaine spray versus placebo, Outcome I Pain scores during procedure (VAS: 0-100).

Review: Pain relief for women with cervical intraepithelial neoplasia undergoing colposcopy treatment

Comparison: 9 Cocaine spray versus placebo

Outcome: I Pain scores during procedure (VAS: 0-100)

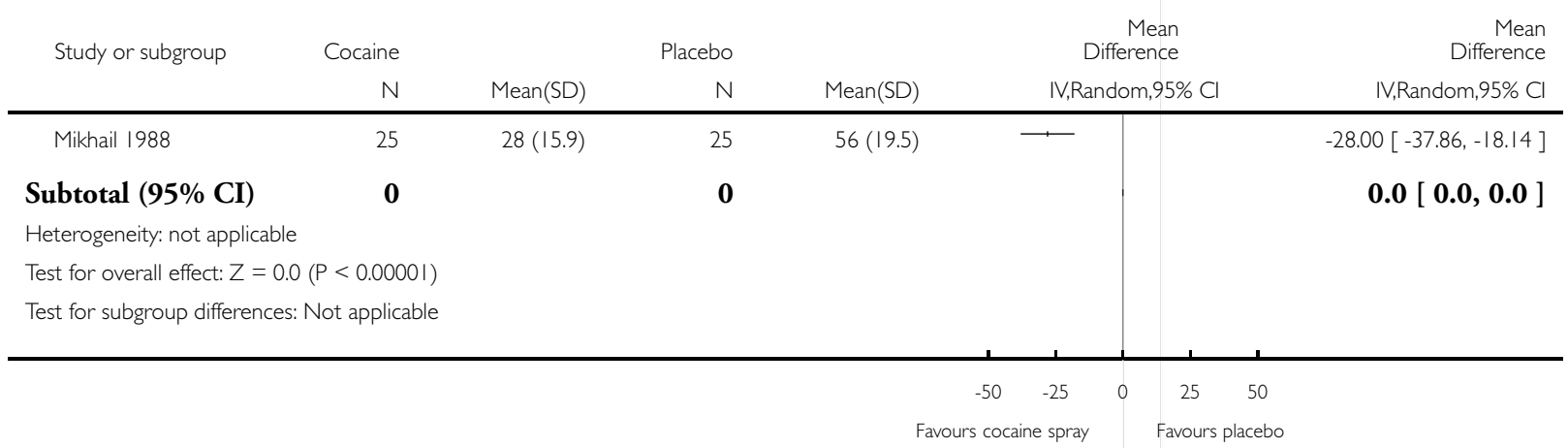




\section{Analysis 9.2. Comparison 9 Cocaine spray versus placebo, Outcome 2 Moderate to severe pain.}

Review: Pain relief for women with cervical intraepithelial neoplasia undergoing colposcopy treatment

Comparison: 9 Cocaine spray versus placebo

Outcome: 2 Moderate to severe pain

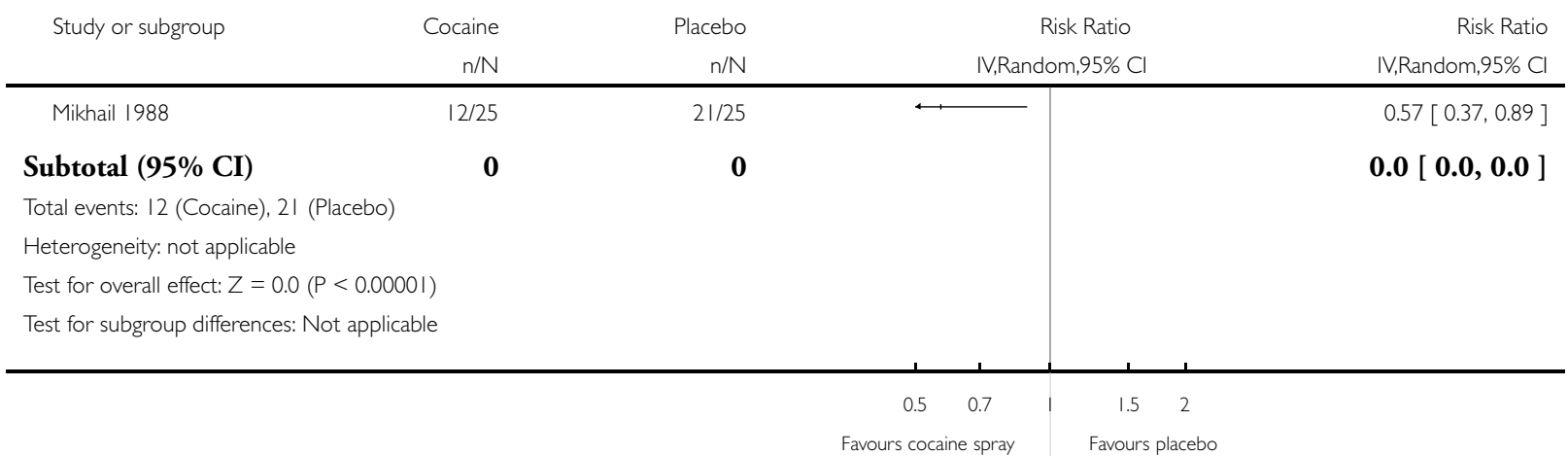

\section{Analysis 9.3. Comparison 9 Cocaine spray versus placebo, Outcome 3 Troublesome bleeding.}

Review: Pain relief for women with cervical intraepithelial neoplasia undergoing colposcopy treatment

Comparison: 9 Cocaine spray versus placebo

Outcome: 3 Troublesome bleeding

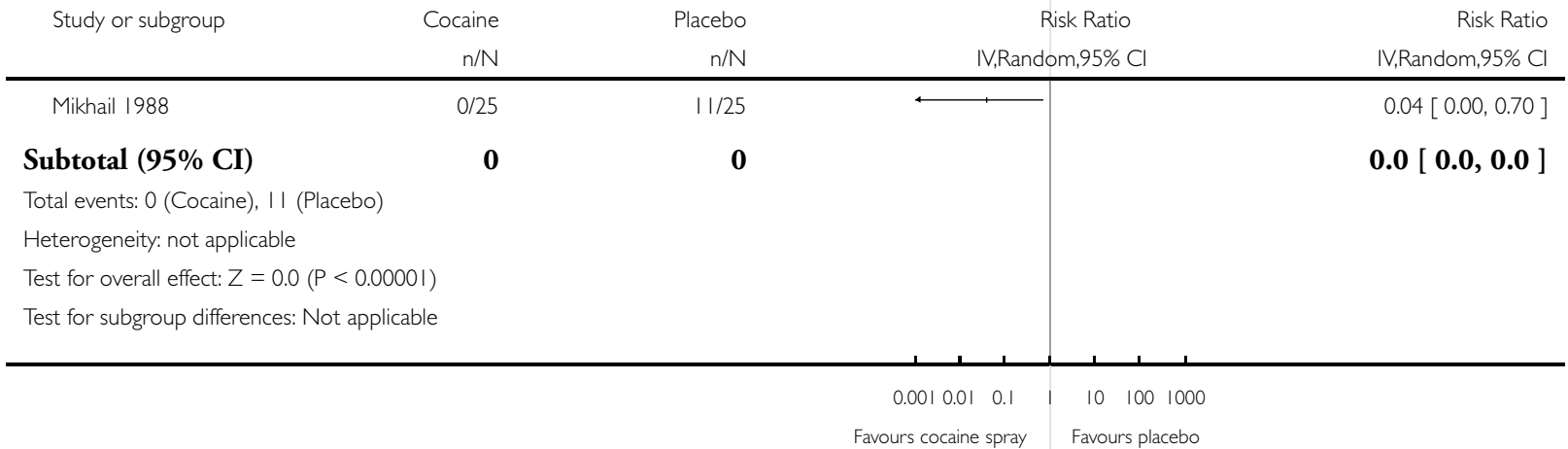




\section{Analysis 10.I. Comparison 10 TENS versus TENS plus local anaesthetic injection, Outcome I Troublesome blood loss.}

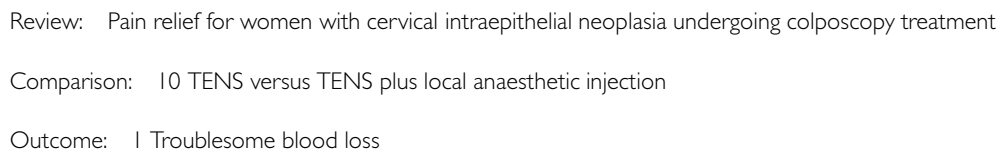

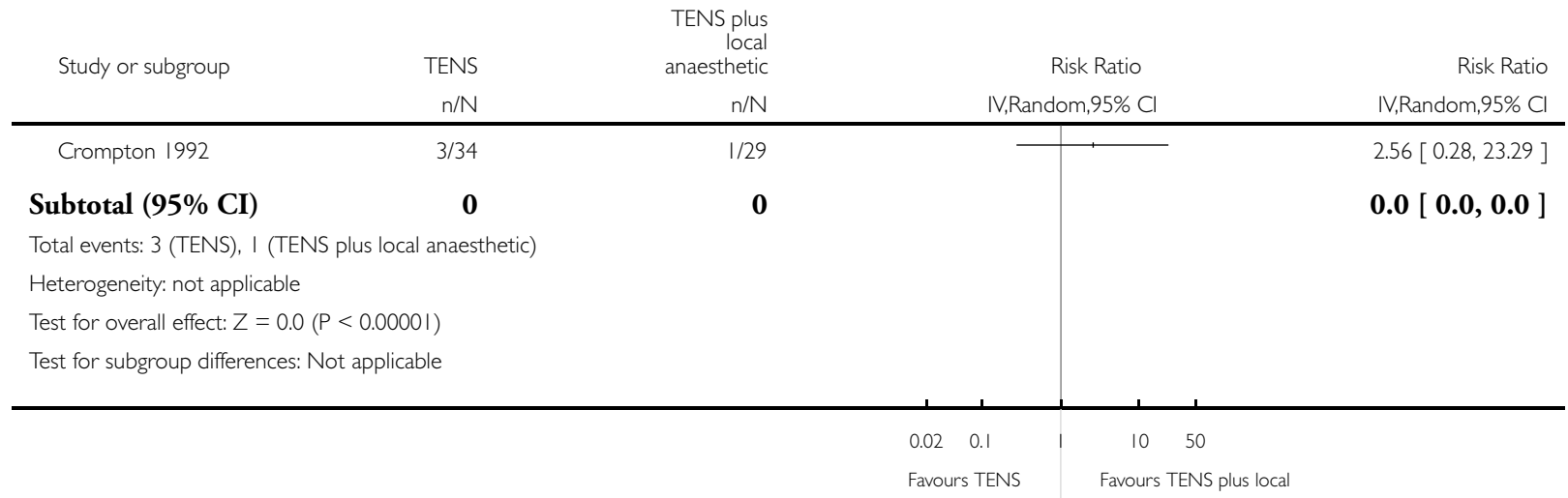

\section{Analysis II.I. Comparison I I TENS versus local anaesthetic injection, Outcome I Troublesome blood loss.}

Review: Pain relief for women with cervical intraepithelial neoplasia undergoing colposcopy treatment

Comparison: II TENS versus local anaesthetic injection

Outcome: | Troublesome blood loss

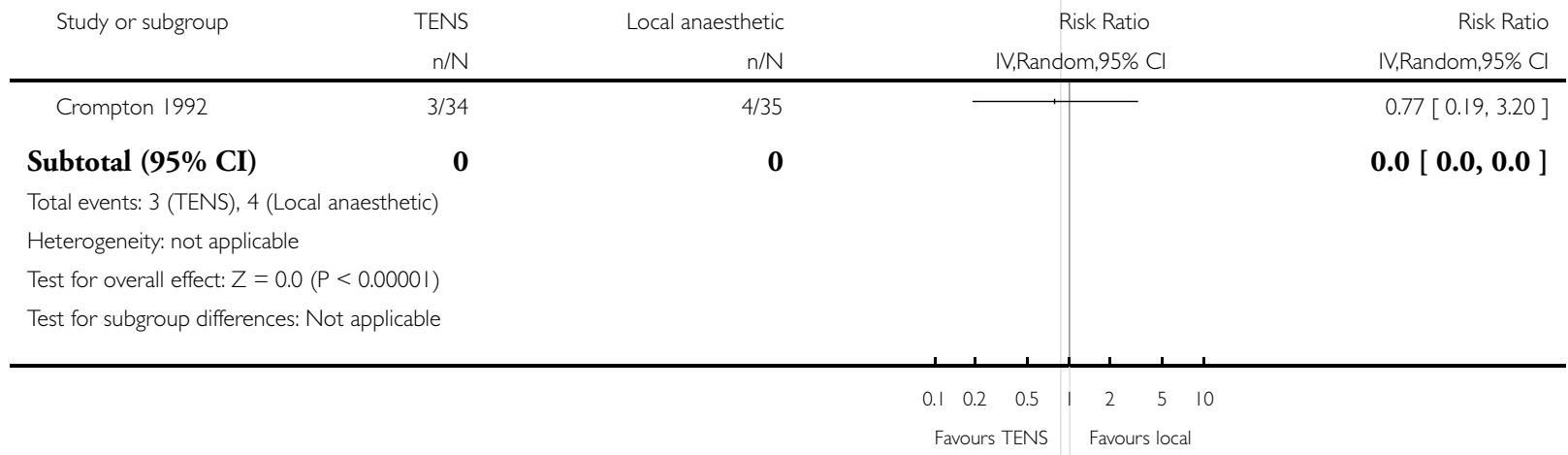




\section{Analysis 12.I. Comparison I2 TENS plus local versus local anaesthetic injection, Outcome I Troublesome blood loss.}

Review: Pain relief for women with cervical intraepithelial neoplasia undergoing colposcopy treatment

Comparison: 12 TENS plus local versus local anaesthetic injection

Outcome: I Troublesome blood loss

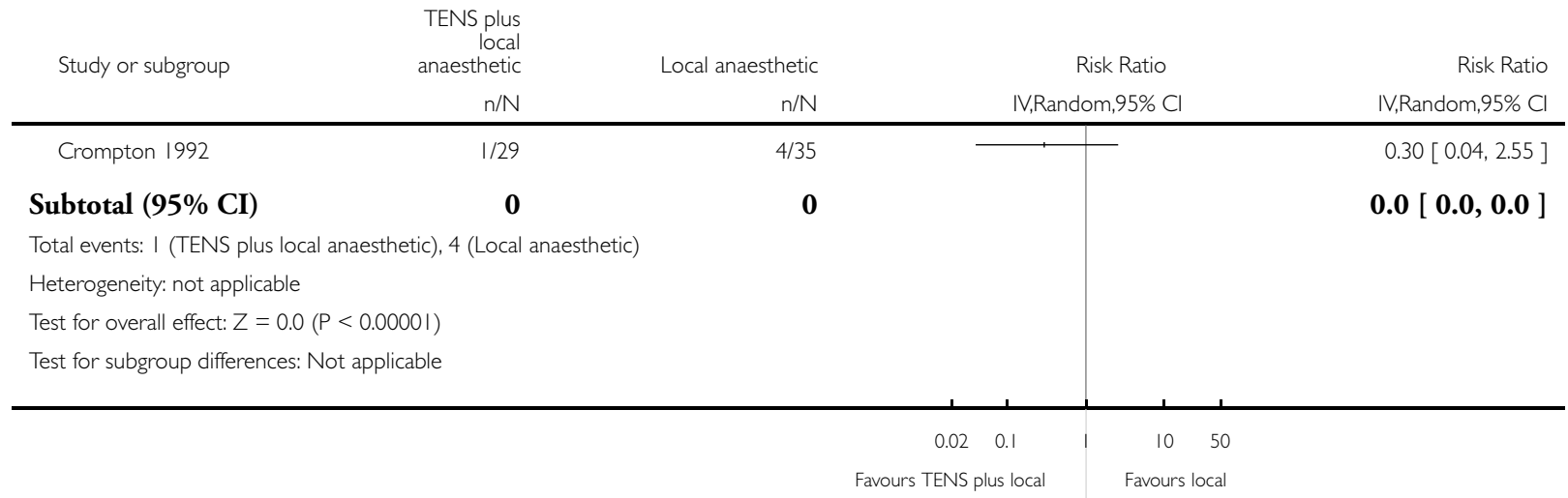

\section{ADDITIONAL TABLES}

Table 1. Overview of included studies

\begin{tabular}{|c|c|c|c|c|}
\hline Study & $\begin{array}{l}\text { Participants' character- } \\
\text { istics }\end{array}$ & Interventions & Outcomes & Notes \\
\hline Al Kurdi 1985 & $\begin{array}{l}97 \text { women, undergoing } \\
\mathrm{CO}_{2} \text { laser treatment for } \\
\mathrm{CIN} \\
\text { Aged } 18 \text { to } 50 \text { years }\end{array}$ & $\begin{array}{l}\text { Intervention group: }(\mathrm{N}= \\
50) \\
2 \text { tablets naproxen } \\
\text { sodium } 550 \mathrm{mg} \\
\text { Comparison group: }(\mathrm{N}= \\
47) \\
2 \text { placebo tablets } \\
\text { Given no less than } 30 \\
\text { minutes before procedure }\end{array}$ & $\begin{array}{l}\text { Pain relief: } \\
\text { VAS on } 10-\mathrm{cm} \text { scale } \\
\text { VRS: (none, very slight, } \\
\text { mild, moderate, severe) } \\
\text { Speed of procedure } \\
\text { Use of analgesia in first } 24 \\
\text { hours }\end{array}$ & $\begin{array}{l}\text { Self-reported side effects } \\
\text { were very minor (aches } \\
\text { and pains at } 24 \text { hours) and } \\
\text { not included in analysis }\end{array}$ \\
\hline Connell 2000 & $\begin{array}{l}30 \text { women undergoing } \\
\text { LLETZ } \\
\text { Aged } 20 \text { to } 64 \text { years }\end{array}$ & $\begin{array}{l}\text { Intervention group: }(\mathrm{N}= \\
15) \\
\text { lignocaine hydrochloride } \\
10 \% \text { spray } \\
\text { Comparison group: }(\mathrm{N}= \\
15) \\
\text { saline spray } \\
\text { Both group received } 4.4\end{array}$ & $\begin{array}{l}\text { Pain relief: } \\
\text { VAS on 100-mm scale } \\
\text { and } \\
\text { 4-point categorical scale } \\
1-4 ; 1=\text { not painful; } 2 \\
=\text { slightly painful; } 3= \\
\text { moderately painful; } 4= \\
\text { severely painful }\end{array}$ & $\begin{array}{l}\text { The outcome reported on } \\
\text { categorical scale was not } \\
\text { included in the analysis }\end{array}$ \\
\hline
\end{tabular}

Pain relief for women with cervical intraepithelial neoplasia undergoing colposcopy treatment (Review) 


\begin{tabular}{|c|c|c|c|c|}
\hline & & $\begin{array}{l}\mathrm{mL} \text { of local anaesthetic } \\
\text { (prilocaine hydrochloride } \\
30 \mathrm{mg} / \mathrm{mL} \text { with } \\
\text { felypressin } 0.54 \mu \mathrm{g} / \mathrm{mL} \text { ) } \\
\text { in the cervix }\end{array}$ & & \\
\hline Crompton 1992 & $\begin{array}{l}98 \text { women undergoing } \\
\mathrm{CO}_{2} \text { laser treatment for } \\
\mathrm{CIN} \\
\text { Linear analogue anxiety } \\
\text { and HAD anxiety/de- } \\
\text { pression personality trait } \\
\text { scores (Zigmond 1983) } \\
\text {, age and parity were } \\
\text { recorded to assess group } \\
\text { comparability } \\
\text { 3-arm trial }\end{array}$ & $\begin{array}{l}\text { (1) TENS }(\mathrm{N}=34) \text { vs. } \\
\text { (2) TENS plus direct in- } \\
\text { filtration of } 2 \mathrm{~mL} \text { ligno- } \\
\text { caine } 2 \% \text { plus octapressin } \\
1: 10,000(0.03 \mathrm{IU} / \mathrm{mL}) \\
(\mathrm{N}=29) \\
\text { (3) Direct infiltration of } \\
2 \text { mL lignocaine } 2 \% \text { plus } \\
\text { octapressin }(\mathrm{N}=35)\end{array}$ & $\begin{array}{l}\text { Pain relief: VAS on } 120- \\
\text { mm scale }\end{array}$ & $\begin{array}{l}\text { Median pain score was on } \\
120 \text {-mm VAS; however, } \\
\text { authors converted it to } \\
\text { percentage for reporting }\end{array}$ \\
\hline Cruickshank 2005 & $\begin{array}{l}389 \text { women undergo- } \\
\text { ing LLETZ treatment for } \\
\text { CIN } \\
\text { Mean age for intervention } \\
\text { group } 32.7 \text { years and for } \\
\text { control } 31.5 \text { years }\end{array}$ & $\begin{array}{l}\text { Intervention group: ( } \mathrm{N}= \\
195) \\
\text { isoflurane and desflurane } \\
\text { gases } \\
\text { Comparison group: ( } \mathrm{N}= \\
194) \\
\text { placebo (air) } \\
\text { Both groups also re- } \\
\text { ceived infiltration of the } \\
\text { cervix with prilocaine hy- } \\
\text { drochloride ( } 30 \mathrm{mg} / \mathrm{mL}) \\
\text { and octapressin }(0.54 \mathrm{mg} / \\
\mathrm{mL} \text { ) }\end{array}$ & $\begin{array}{l}\text { Pain relief: VAS on } 100- \\
\text { mm scale } \\
\text { Heavy vaginal bleeding } \\
\text { (yes/no) } \\
\text { Anxiety using HAD scale }\end{array}$ & $\begin{array}{l}\text { Acceptability, satisfac- } \\
\text { tion, helpfulness and will- } \\
\text { ingness to undergo proce- } \\
\text { dures in future - not in- } \\
\text { cluded in analysis }\end{array}$ \\
\hline Diakomanolis 1997 & $\begin{array}{l}100 \text { women undergoing } \\
\mathrm{CO}_{2} \text { laser for CIN. } \\
\text { Median age for interven- } \\
\text { tion group } 28 \text { years and } \\
\text { for comparison group } 28 . \\
5 \text { years }\end{array}$ & $\begin{array}{l}\text { Intervention group: ( } \mathrm{N}= \\
50) \\
30 \mathrm{~mL} \text { of a } 1: 30 \text { POR8 } \\
\text { (vasoconstrictor) + ligno- } \\
\text { caine } 1 \% \text { solution } \\
\text { Comparison group (lig- } \\
\text { nocaine only): }(\mathrm{N}=50) \\
30 \mathrm{~mL} \text { of lignocaine } 1 \% \\
\text { solution }\end{array}$ & $\begin{array}{l}\text { Pain relief: } \\
\text { VRS (none, moderate, se- } \\
\text { vere) } \\
\text { Intra-operative blood loss } \\
\text { Duration of procedure }\end{array}$ & $\begin{array}{l}\text { Side effects - transient hy- } \\
\text { pertension and sweating }\end{array}$ \\
\hline Duncan 2005 & $\begin{array}{l}97 \text { women undergoing } \\
\text { treatment with Semm co- } \\
\text { agulator } \\
\text { Intervention: } \mathrm{N}=46 \text {, } \\
\text { mean age } 31.3(\mathrm{SD} 8.4) \\
\text { Comparison: } \mathrm{N}=47 \text {, } \\
\text { mean age } 32.6(\mathrm{SD} 8.0) \\
\text { Nullipara: intervention: }\end{array}$ & $\begin{array}{l}\text { Intervention group: }(\mathrm{N}= \\
46) \\
5-\mathrm{mL} \text { vials of prilocaine } \\
3 \%(30 \mathrm{mg} / \mathrm{mL}) \text { with } \mathrm{fe}- \\
\text { lypressin } 0.03 \mathrm{IU} / \mathrm{mL} \\
\text { Comparison group: }(\mathrm{N}= \\
47) \\
\text { normal saline }\end{array}$ & $\begin{array}{l}\text { Pain relief: } \\
\text { 11-point analogue scale, } \\
\text { 1-3, mild; 4-7, moderate; } \\
\text { 8-10, severe pain }\end{array}$ & $\begin{array}{l}\text { Details of anticipated } \\
\text { pain were excluded from } \\
\text { the analysis }\end{array}$ \\
\hline
\end{tabular}


Table 1. Overview of included studies (Continued)

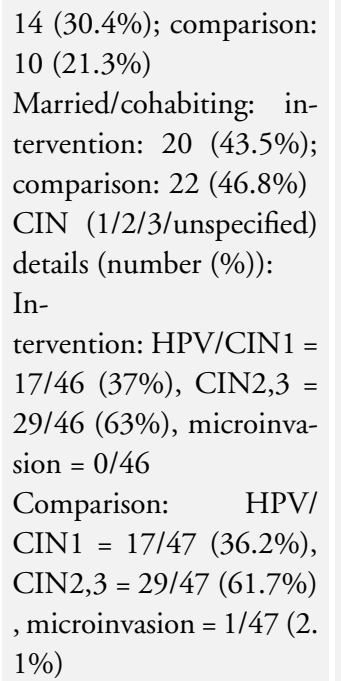

\begin{tabular}{|l|l|l|} 
Frega 1994 women undergoing & (1) Naproxen sodium 550 Pain relief on \\
& $\begin{array}{l}63 \text { laser vaporisation } \\
\text { mg } 30 \text { minutes before }\end{array}$ & VAS 100-mm scale \\
for CIN & treatment, $\mathrm{N}=21$ \\
3- arm trial & $\begin{array}{l}\text { (2) Placebo } 30 \text { minutes } \\
\text { before treatment, } \mathrm{N}=21 \\
\text { and } \\
\text { (3) No drug, } \mathrm{N}=21\end{array}$ \\
\end{tabular}

Howells 2000

200 women, aged 20-60 Intervention group: $(\mathrm{N}=$ Duration of procedure

Other side effects, such as years, undergo- 94) Degree of bleeding $(0=$ feeling faint, nausea and ing LLETZ for CIN (final prilocaine 3\% (30 mg/ none; 5 = heavy) histology was negative for $\mathrm{mL}$ ) with felypressin 0.03 Pain relief: shaking, were also scored 4/94 in intervention arm IU/mL (Citanest) patient reported $(0=a$ similar fashion $(0=$ and $8 / 106$ in comparison arm) Comparison group: $(\mathrm{N}=$ none; $5=$ unbearable $)$ none; 5 = a great deal)

Characteristic for prilo- lignocaine

caine with felypressin (N 2\% with adrenaline 1:80,

=94) vs. lignocaine with 000 (xylocaine)

adrenaline $(\mathrm{N}=106)$

Age (years) - mean (SD):

$36.6(10.3)$ vs. $34.6(9.7)$

\begin{tabular}{|c|c|c|c|c|}
\hline Johnson 1989 & $\begin{array}{l}70 \text { women undergoing } \\
\mathrm{CO}_{2} \text { laser ablation for } \\
\text { cervical dysplastic lesion } \\
\text { Size of transformation } \\
\text { zone was recorded as a } \\
\text { score out of } 2 \\
\text { Intervention group: } 1.4 \\
\text { vs. } \\
\text { comparison group: } 1.2\end{array}$ & $\begin{array}{l}\text { Bilat- } \\
\text { eral paracervical block by } \\
\text { injecting } 10 \mathrm{~mL} \text { into the } \\
\text { paracervical tissues } \\
\text { Intervention group: }(\mathrm{N}= \\
35) \\
\text { lignocaine } 2 \% \\
\text { Comparison group: }(\mathrm{N}= \\
35)\end{array}$ & $\begin{array}{l}\text { Pain relief: } \\
\text { VAS on } 120-\mathrm{mm} \text { scale } \\
\text { and objective scoring by } \\
\text { nurse and attending oper- } \\
\text { ator } \\
\text { Blood loss (recorded as a } \\
\text { score) }\end{array}$ & $\begin{array}{l}\text { Anxiety and depression } \\
\text { HAD scores (Zigmond } \\
1983 \text { ) and premenstrual } \\
\text { syndrome scores were also } \\
\text { recorded }\end{array}$ \\
\hline
\end{tabular}


Table 1. Overview of included studies (Continued)

normal saline

\begin{tabular}{|c|c|c|c|c|}
\hline Johnson 1996 & $\begin{array}{l}44 \text { women undergoing } \\
\mathrm{CO}_{2} \text { laser treatment for } \\
\mathrm{CIN}\end{array}$ & $\begin{array}{l}\text { Intervention group: }(\mathrm{N}= \\
23 \text { ) } \\
10 \mathrm{~mL} \text { of paracervical } 2 \% \\
\text { lignocaine } \\
\text { Comparison group: }(\mathrm{N}= \\
21 \text { ) } \\
2 \mathrm{~mL} \text { of lignocaine } 2 \% \text { di- } \\
\text { rectly into the } \mathrm{TZ}\end{array}$ & $\begin{array}{l}\text { Pain relief: } \\
\text { VAS (expressed as per- } \\
\text { centage) and } \\
\text { objective scoring by nurse } \\
\text { and laser operator }\end{array}$ & \\
\hline Lee 1986 & $\begin{array}{l}50 \text { women under- } \\
\text { going laser vaporisation of } \\
\text { cervix for CIN }\end{array}$ & $\begin{array}{l}\text { Intervention group: }(\mathrm{N}= \\
25) \\
\text { ectocervix was infiltrated } \\
\text { with } 2 \mathrm{~mL} \text { of citanest } \\
\text { (prilocaine } 3 \% \text { with } 0.03 \\
\text { IU/mL of felypressin) } \\
\text { Control group: }(\mathrm{N}=25) \\
\text { no analgesia or anaesthe- } \\
\text { sia }\end{array}$ & $\begin{array}{l}\text { Pain relief: } \\
\text { VAS on 100-mm scale } \\
\text { (VRS none, mild, moder- } \\
\text { ate or severe) } \\
\text { Blood loss: none, slight, } \\
\text { moderate, troublesome }\end{array}$ & $\begin{array}{l}\text { Side effects such as sweat- } \\
\text { ing, nausea, dizziness and } \\
\text { cramps were also reported } \\
\text { but not included in analy- } \\
\text { sis as they were minor side } \\
\text { effects }\end{array}$ \\
\hline
\end{tabular}

Lipscomb 1995

50 women scheduled for Intervention group: $(\mathrm{N}=$ the loop electrosurgical 25)

Pain relief:

excision for treatment of cervical application of

VAS on $10-\mathrm{cm}$ scale

CIN

benzocaine gel $20 \%$

Age - mean (SD): inter- Comparison group: $(\mathrm{N}=$ vention group: 29.5 (10. 25)

$5)$ and comparison group: placebo gel

$28.4(8.9)$

After 1 minute of gel apParity - mean (SD): inter- plication, $4 \mathrm{~mL}$ of lignovention group: 2.1 (2.1) caine $1 \%$ with adrenaline and comparison group: 2. 1:100,000 was injected in 3 (1.6) cervix

\section{(1)}

Loop passes: mean (SD)

: intervention group: 1 .

2 (0.4) and comparison group: $1.3(0.6)$

positive margins:

Mean (SD): intervention group: $2 / 25$ and comparison group: $3 / 25$

50 women undergoing Intervention group: $(\mathrm{N}=$ laser vaporisation of the 25 cervix for CIN Intervention group: mean (SD): age: 27.4 (3.9); parity: 0 . $9(1.24)$ cervix was sprayed with 3$4 \mathrm{~mL}$ of a cocaine $10 \%$ solution

Comparison group: $(\mathrm{N}=$ 25)
Duration of procedure Blood loss: minimal, moderate, severe Pain relief: VAS on $100-\mathrm{mm}$ scale and VRS: none, mild, moder- 
Table 1. Overview of included studies (Continued)

\begin{tabular}{|c|c|c|c|c|}
\hline & $\begin{array}{l}\text { Comparison group: } \\
\text { age: } 26.7 \text { (4.57); parity: } 1 \\
\text { (1) }\end{array}$ & $\begin{array}{l}\text { cervix sprayed with a sim- } \\
\text { ilar quantity of the preser- } \\
\text { vative alone }\end{array}$ & ate or severe & \\
\hline Rogstad 1992 & $\begin{array}{l}60 \text { women undergoing } \\
\text { cold coagulation for cer- } \\
\text { vical abnormalities }\end{array}$ & $\begin{array}{l}\text { Intervention group: }(\mathrm{N}= \\
29) \\
2 \mathrm{~mL} \text { of lignocaine } 2 \% \\
\text { Comparison group: }(\mathrm{N}= \\
31) \\
\text { normal saline }\end{array}$ & $\begin{array}{l}\text { Pain relief: } \\
\text { VAS on } 0 \text { to } 10 \text { scale and } \\
\text { VRS }\end{array}$ & $\begin{array}{l}\text { Other } \\
\text { outcomes like pain of in- } \\
\text { jection and 3-6 weeks' fol- } \\
\text { low-up questionnaire of } \\
\text { pain and bleeding were } \\
\text { excluded from the analy- } \\
\text { sis }\end{array}$ \\
\hline Sammarco 1993 & $\begin{array}{l}45 \text { women undergoing } \\
\text { cryocoagulation with liq- } \\
\text { uid nitrogen using cryo- } \\
2000 \text { by double-freeze } \\
\text { technique for CIN }\end{array}$ & $\begin{array}{l}\text { Intervention group: }(\mathrm{N}= \\
19) \\
2-3 \mathrm{~mL} \text { of lignocaine } 1 \% \\
+ \text { adrenaline } 1: 100,000 \\
\text { dilution } \\
\text { Comparison group: }(\mathrm{N}= \\
26) \\
\text { no treatment } \\
\text { Both groups also re- } \\
\text { ceived single dose of ke- } \\
\text { toprofen } 75 \text { mg, within } \\
1 \text { hour of the proce- } \\
\text { dure; } 2 \text { women received } \\
\text { naproxen sodium } 550 \mathrm{mg}\end{array}$ & $\begin{array}{l}\text { Pain relief: } \\
\text { VAS on 100-mm scale } \\
\text { Mean VAS score recorded } \\
\text { by nurses was not in- } \\
\text { cluded in analysis owing } \\
\text { to high risk of bias }\end{array}$ & \\
\hline Sarkar 1993 & $\begin{array}{l}70 \text { women undergoing } \\
\text { laser treatment for CIN } \\
\text { Age mean (SD): EMLA } \\
\text { cream: } 27.8 \text { years }(6.3) \\
\text { and placebo: } 28 \text { years }(5 . \\
\text { 4) }\end{array}$ & $\begin{array}{l}\text { Intervention group: }(\mathrm{N}= \\
35) \\
\text { EMLA cream (lignocaine } \\
2.5 \% \text { and prilocaine } 2 . \\
5 \%) \\
\text { Comparison group: }(\mathrm{N}= \\
35) \\
\text { placebo cream }\end{array}$ & $\begin{array}{l}\text { Pain relief: assessed by } \\
\text { McGill's pain question- } \\
\text { naire (Melzack 1975) and } \\
\text { the } \\
\text { VAS } \\
\text { Blood loss: none, mild, } \\
\text { moderate, troublesome }\end{array}$ & $\begin{array}{l}\text { Minor adverse experi- } \\
\text { ences during treatment } \\
\text { such as feeling hot, sweat- } \\
\text { ing, dizziness, fainting } \\
\text { and sickness were not in- } \\
\text { cluded in analysis }\end{array}$ \\
\hline Winters 2009 & $\begin{array}{l}60 \text { women undergoing } \\
\text { LLETZ for CIN }\end{array}$ & $\begin{array}{l}\text { Intervention group: }(\mathrm{N}= \\
30 \text { ) } \\
\text { prilocaine } 3 \% \text { with fe- } \\
\text { lypressin injected deep } \\
\text { into the cervical stroma } \\
\text { around } \mathrm{TZ} \\
\text { Comparison group: }(\mathrm{N}= \\
30 \text { ) } \\
\text { prilocaine } 3 \% \text { with fe- } \\
\text { lypressin injected super- } \\
\text { ficial followed by deep } \\
\text { into the cervical stroma } \\
\text { around } \mathrm{TZ}\end{array}$ & $\begin{array}{l}\text { Pain relief: } \\
\text { VAS on } 100-\mathrm{mm} \text { scale }\end{array}$ & $\begin{array}{l}\text { Pain experienced during } \\
\text { local anaesthetic injection } \\
\text { was also evaluated }\end{array}$ \\
\hline
\end{tabular}

Pain relief for women with cervical intraepithelial neoplasia undergoing colposcopy treatment (Review) 
Table 1. Overview of included studies (Continued)

Same amount used for

both groups

CIN: cervical intraepithelial neoplasia; HAD: Hospital Anxiety and Depression; HPV: human papillomavirus; LLETZ: loop excision of the transformation zone; SD: standard deviation; TENS: transcutaneous electrical nerve stimulation; VAS: visual analogue scale; VRS: verbal rating score; TZ: transformation zone.

\section{AP PENDICES}

\section{Appendix I. CENTRAL search strategy}

\#1 MeSH descriptor Analgesia explode all trees \#2 MeSH descriptor Anesthetics explode all trees \#3 MeSH descriptor Analgesics explode all trees

\#4 MeSH descriptor Pain explode all trees with qualifiers: DT,TH

\#5 MeSH descriptor Anti-Inflammatory Agents, Non-Steroidal explode all trees

\#6 analgesia or analgesic*

$\# 7$ anesthetic* or anaesthetic*

\#8 anti-inflammator*

\#9 transcutaneous electrical nerve stimulation or TENS

$\# 10$ pain next/3 (relief or drug* or therap* or treat*)

\#11 (\#1 OR \#2 OR \#3 OR \#4 OR \#5 OR \#6 OR \#7 OR \#8 OR \#9 OR \#10)

\#12 MeSH descriptor Uterine Cervical Neoplasms explode all trees

\#13 MeSH descriptor Cervical Intraepithelial Neoplasia explode all trees

\#14 MeSH descriptor Uterine Cervical Dysplasia explode all trees

\#15 cervi* near/5 (intraepithel* or dysplasia or cancer* or tumor* or tumour* or neoplas* or carcinoma* or malignan*)

\#16 CIN or CIN1 or CIN2 or CIN3

\#17 (\#12 OR \#13 OR \#14 OR \#15 OR \#16)

\#18 MeSH descriptor Colposcopy explode all trees

\#19 colposcop*

\#20 LLETZ

\#21 LEEP

\#22 excis* or ablat* or laser* or cryosurg*

\#23 (\#18 OR \#19 OR \#20 OR \#21 OR \#22)

\#24 (\#11 AND \#17 AND \#23) 


\section{Appendix 2. MEDLINE search strategy}

MEDLINE Ovid 1950 to present

1 exp Analgesia/

$2 \exp$ Anesthetics/

3 exp Analgesics/

4 exp Pain/dt, th [Drug Therapy, Therapy]

5 exp Anti-Inflammatory Agents, Non-Steroidal/

6 (pain adj3 (relief or drug* or therap* or treat*)).mp.

7 (analgesia or analgesic $\left.{ }^{*}\right) \cdot \mathrm{mp}$.

8 (anesthetic* or anaesthetic*).mp.

9 anti-inflammator*.mp.

10 (Transcutaneous Electrical Nerve Stimulation or TENS).mp.

111 or 2 or 3 or 4 or 5 or 6 or 7 or 8 or 9 or 10

12 exp Uterine Cervical Neoplasms/

13 Cervical Intraepithelial Neoplasia/

14 Uterine Cervical Dysplasial

15 (cervi* adj5 (intraepithel* or dysplasia or cancer* or tumor* or tumour* or neoplas* or carcinoma* or malignan*)).mp.

16 (CIN or CIN1 or CIN2 or CIN3).mp.

1712 or 13 or 14 or 15 or 16

18 Colposcopy/

19 colposcop*.mp.

20 LLETZ.mp.

21 LEEP.mp.

22 (excis* or ablat* or laser* or cryosurg*).mp.

2318 or 19 or 20 or 21 or 22

2411 and 17 and 23

key:

$\mathrm{mp}=$ title, original title, abstract, name of substance word, subject heading word, unique identifier

\section{Appendix 3. EMBASE search strategy}

EMBASE Ovid 1980 to present

1 exp analgesia/

2 exp anesthetic agent/

3 exp analgesic agent/

4 exp pain/dt, th [Drug Therapy, Therapy]

5 exp nonsteroid antiinflammatory agent/

6 (pain adj3 (relief or drug* or therap* or treat*)).mp.

7 (analgesia or analgesic $\left.{ }^{*}\right) \cdot \mathrm{mp}$.

8 (anesthetic* or anaesthetic*).mp.

9 anti-inflammator*.mp.

10 transcutaneous nerve stimulation/

11 (transcutaneous electrical nerve stimulation or TENS).mp.

121 or 2 or 3 or 4 or 5 or 6 or 7 or 8 or 9 or 10 or 11

13 exp uterine cervix tumor/

14 uterine cervix dysplasia/

15 uterine cervix carcinoma in situ/

16 (cervi* adj5 (intraepithel* or dysplasia or cancer* or tumor* or tumour* or neoplas* or carcinoma* or malignan*)).mp.

17 (CIN or CIN1 or CIN2 or CIN3).mp.

1813 or 14 or 15 or 16 or 17

19 colposcopy/

20 colposcop* $^{*} \cdot \mathrm{mp}$.

Pain relief for women with cervical intraepithelial neoplasia undergoing colposcopy treatment (Review)

Copyright $\odot 2012$ The Cochrane Collaboration. Published by John Wiley \& Sons, Ltd. 
21 LLETZ.mp.

22 LEEP.mp.

23 (excis* or ablat* or laser* or cryosurg*).mp.

2419 or 20 or 21 or 22 or 23

2512 and 18 and 24

key:

$\mathrm{mp}=$ title, abstract, subject headings, heading word, drug trade name, original title, device manufacturer, drug manufacturer

\section{H I S T O R Y}

Protocol first published: Issue 3, 2006

Review first published: Issue 10, 2012

Date Event Description

24 June 2008 Amended Converted to new review format.

\section{CONTRIBUTIONSOFAUTHORS}

Ketan Gajjar - primary author.

Andrew Bryant - statistical and methodological support.

Pierre Martin-Hirsch - editing and clinical expertise.

\section{DECLARATIONSOF INTEREST}

None.

\section{SOURCESOF S P PORT}

\section{Internal sources}

- No sources of support supplied

\section{External sources}

- Department of Health, UK.

NHS Cochrane Collaboration programme Grant Scheme CPG-10/4001/12 


\section{DIFFERENCES BETWEEN PROTOCOLANDREVIEW}

We did not identify any ongoing trials so the following sentence was removed from the 'searching other resources section':

- "If ongoing trials which have not been published are identified through these searches, the principal investigators will be approached for relevant data."

The review included 17 trials but comparisons were restricted to single trial analyses or meta-analysis of few trials so the following section on reporting biases was removed:

- "Assessment of reporting biases Funnel plots corresponding to meta-analysis of the primary outcome will be examined to assess the potential for small study effects. When there is evidence of small-study effects, publication bias will be considered as only one of a number of possible explanations. If these plots suggest that treatment effects may not be sampled from a symmetric distribution, as assumed by the random effects model, sensitivity analyses will be performed using fixed effects models."

Subgroup analyses were not carried out so we removed the following section:

- "Subgroup analysis and investigation of heterogeneity If possible, subgroup analysis will be performed, grouping the trials by different routes of administering analgesia i.e. oral, injectable or inhalation and pain relief for different treatment types. Factors such as age, CIN grade, length of follow-up, adjusted/unadjusted analysis will be considered in interpretation of any heterogeneity."

We did not carry out sensitivity analysis. We had specified the following in the protocol:

- "Sensitivity analysis We will perform sensitivity analyses excluding studies at moderate or high risk of bias."

\section{NDEX TERMS}

\section{Medical Subject Headings (MeSH)}

Administration, Oral; Analgesics [*administration \& dosage]; Cervical Intraepithelial Neoplasia [* surgery]; Colposcopy [*adverse effects]; Drug Therapy, Combination [methods]; Intraoperative Complications [ ${ }^{*}$ therapy]; Pain Management [* methods]; Pain Measurement; Pain, Postoperative [* therapy]; Randomized Controlled Trials as Topic; Transcutaneous Electric Nerve Stimulation [methods]; Uterine Cervical Neoplasms [* surgery]

\section{MeSH check words}

Adult; Female; Humans 